\title{
Высшая школа
}

экономики

и менеджмента

\section{БАРЬЕРЫ И ВОЗМОЖНОСТИ ДЛЯ РАЗВИТИЯ БИЗНЕСА В РОССИЙСКОЙ ЭКОНОМИКЕ}

\section{Монография}




\section{БАРЬЕРЫ И ВОЗМОЖНОСТИ ДЛЯ РАЗВИТИЯ БИЗНЕСА В РОССИЙСКОЙ ЭКОНОМИКЕ}




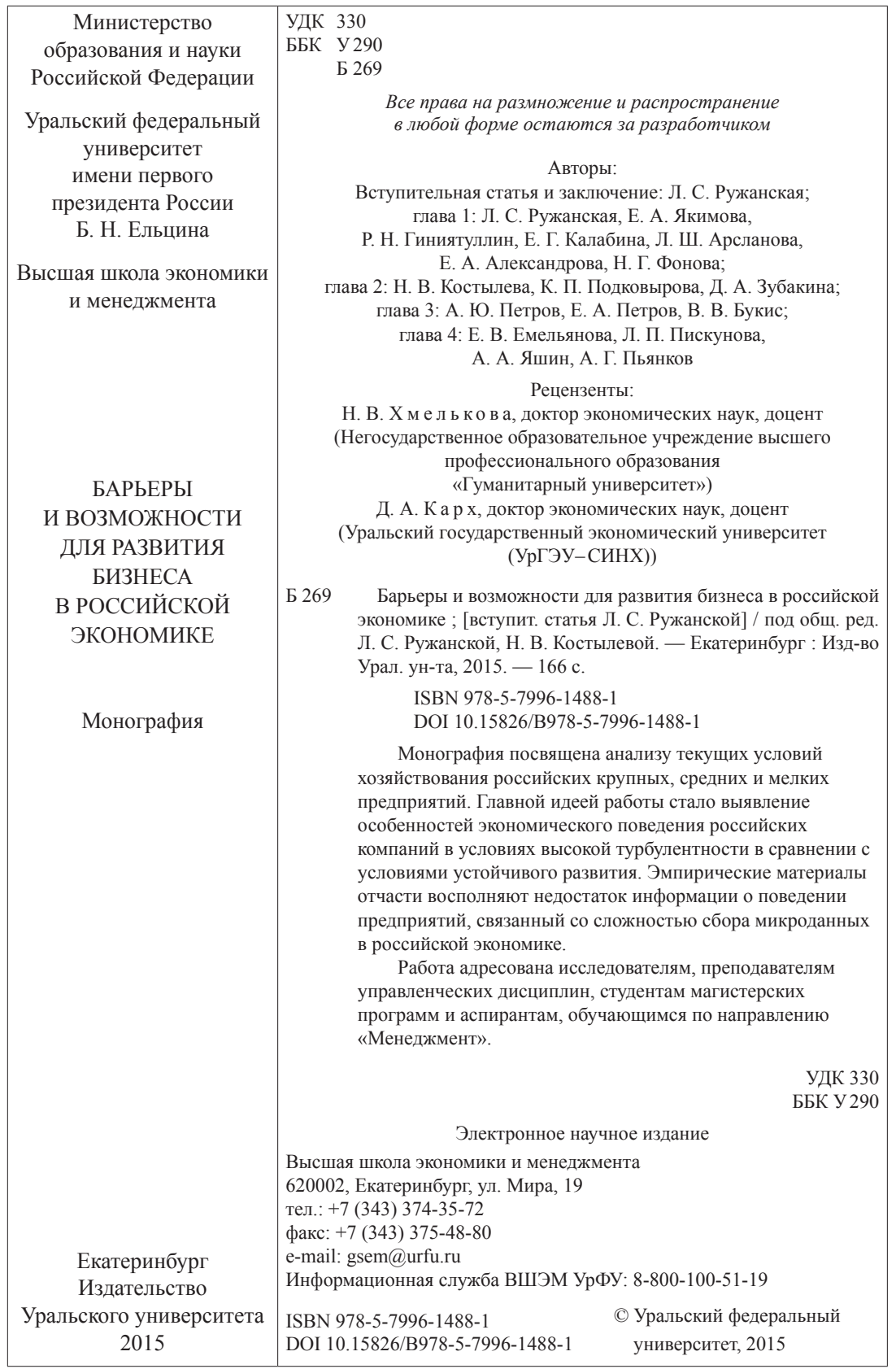




\section{ИЗМЕНЕНИЕ СТРАТЕГИЙ РОССИЙСКИХ ПРЕДПРИЯТИЙ В УСЛОВИЯХ ЭКОНОМИЧЕСКИХ КРИЗИСОВ}

Работа посвящена рассмотрению проблем развития крупных, средних и мелких компаний в современных условиях хозяйствования в российской экономике, для которой характерны гетерогенность среды, а это, в свою очередь, вызывает множественные реакции со стороны компаний и разнообразие стратегий их развития.

Монография - коллективный труд авторов, которых объединяет многолетнее сотрудничество в рамках одной кафедры теории и практики менеджмента Уральского федерального университета. Авторы демонстрируют единство исследовательского подхода, предполагающего многообразие характеристик исследуемых объектов и множественность использованных методик.

В последние годы тезис о неоднородности среды хозяйствования и стратегий развития российских предприятий повторялся многократно. Более того, колебания экономической конъюнктуры ставят перед исследователями задачу не только поиска ответа на вопрос о том, что ограничивает или стимулирует развитие компаний, но и более актуальный вопрос, как обеспечить устойчивое развитие отдельных компаний и экономики в целом.

Российская экономика является молодой: реформам, давшим запуск рыночным механизмам хозяйствования, чуть более 20 лет. Тем не менее этот период можно разбить на три этапа развития российской экономики:

- 1990-1998 гг. характеризуется лавинообразными реформами и трансформационным кризисом. За этот период снижение ВВП составило 40 \%, что стало не только шоком для хозяйствующих субъектов, но и научило быстро приспосабливаться и адаптироваться к изменяющейся внешней среде; 
- 1999-2008 гг. можно охарактеризовать как период восстановительного роста, в котором опорными факторами развития стали новые ресурсы и внешняя рента, обеспеченная сырьевым экспортом; именно в этот период рост производительности труда в среднем по экономике составил 70 \%, Россия попала в категорию растущих рынков, привлекательных для внешних инвестиций;

- 2009 г. - по настоящее время представляет собой новый этап, в котором проявились болезни роста экономики на долгосрочном промежутке, к важнейшим из которых можно отнести не доведенные до конца институциональные преобразования; слабость экономической инфраструктуры; незащищенность прав собственности. С 2013 г. темпы роста ВВП в Российской Федерации оказались ниже, чем в развитых странах, а с 2015 г. наступила рецессия, время завершения которой не берется предугадать никто из экспертов.

Причиной нынешнего кризиса стало торможение в модернизации экономики, которую в стране стали проводить с 1999 г., опираясь на внешние факторы. При этом модернизация понималась и понимается совершенно справедливо как рост производительности труда быстрее, чем в развитых странах. На третьем этапе развития требуется новая институциональная система, обеспечивающая эффективность рыночной экономики. Критической точкой развития стал кризис 2014 г., в течение которого, в отличие от кризиса 2008-2009 гг., у государства отсутствовала возможность использования резервных фондов для поддержания спада в средних и крупных предприятиях.

Природа экономического кризиса на макроуровне изучена довольно хорошо, тем более что авторы опираются на богатую статистику и детальное описание предшествовавших кризисов и их проявлений как в отечественной, так и в мировой экономике. Сегодня проблема кризиса на микроуровне изучается слабо, в том числе на уровне отдельных предприятий и их объединений, исключения составляют разве что работы авторов из Института анализа предприятий и рынков НИУ Высшая школа экономики (Москва). 
Авторы столкнулись с объективными сложностями, связанными с особенностями российской бизнес-среды, создающими трудности в сборе микроданных. В монографии представлены результаты использования количественных и качественных подходов исследования, дающих возможность преодолеть вышеотмеченную трудность. В книге собран значительный объем эмпирических данных, характеризующих современную практику работы компаний.

Работа состоит из четырех глав, объединяющих исследования по близким вопросам. В первой главе «Особенности экономического поведения российских предприятий» авторы определяют базовые особенности экономического поведения российских предприятий, выражающиеся в информационной закрытости, стремлении к созданию входных отраслевых барьеров рыночными и нерыночными методами и закрытости структуры собственности. Специфической детерминантой поведения средних и крупных российских компаний является тесная взаимосвязь с государством, которое в период институциональных трансформаций и экономических кризисов начинает усиливать свое влияние в экономике. Особая роль государства в российской экономике проявляется в системе обменов между компаниями и государством на всех уровнях. Новым и одновременно старым фактором, формирующим стратегию развития российских предприятий, является их юнионизация - включенность работников в профсоюзные организации. Заполняя вакуум формальных институтов, регулирующих контрактные отношения на фирме, работники все активнее включаются в создание и реальное использование профсоюзов. Авторы подчеркивают новую роль профсоюзов как элемент зрелости рыночных реформ. Кроме того, также подчеркивается гетерогенность реакций компаний на изменения внешней среды.

Во второй главе «Глобализация российской экономики как детерминанта экономического поведения российских предприятий» исследуются актуальные вопросы нынешнего экономического кризиса, связанные с новым макроэкономическим риском для предприятий — геополитическим фактором. Во внешней среде отечественных предприятий глобализация и демократизация - это 
мощные трансформирующие силы. И одним из центров развития на современной карте мира стала китайская экономика. Авторы анализируют, какие возможности открываются для региональных компаний (Свердловская область) в свете роста роли китайского фактора на мировой арене.

Третья глава монографии «Стратегии развития российских предприятий в условиях кризиса» представляет отдельные функциональные стратегии компаний, которые используются ими в кризисных условиях и в периоды стабильного развития. В условиях кризиса особое внимание компании среднего и малого бизнеса уделяют лояльности клиентов и удержанию клиентской базы, а также развитию знаний и навыков сотрудников компаний как важного нематериального актива.

В четвертую главу «Особенности развития рынков», основанную на региональных материалах, вошел анализ потребительского поведения студенческой молодежи как наиболее новаторской части населения с точки зрения поведенческих характеристик, а также анализ условий формирования транспортно-логистических систем и фешн-индустрии относительно новых секторов экономики, ищущих свою самоидентификацию и пытающегося самоорганизоваться для повышения конкурентоспособности.

Выводы авторов подкрепляются результатами проведенных ими полевых и кабинетных исследований. Практическая значимость работы обусловлена разработанными рекомендациями.

РУЖАНСКАЯ, Людмила Станиславовна заведующий кафедрой теории и практики менеджмента ВШЭМ УрФУ 


\section{Глава 1 \\ ОСОБЕННОСТИ ЭКОНОМИЧЕСКОГО ПОВЕДЕНИЯ РОССИЙСКИХ ПРЕДПРИЯТИЯ}

\section{§ 1. Закрытый тип экономического поведения крупного российского бизнеса: опыт монографического исследования}

В отечественной литературе существует богатая традиция исследования предприятий в условиях институциональных изменений, начиная с постперестроечного периода. Как отметили Т. Г. Долгопятова, И. Ивасаки и А. А. Яковлев [1] ключевой компонентой перехода стало радикальное изменение институциональной среды. Эволюция экономического поведения российский крупных предприятий проходила в несколько этапов: от возобновления паттернов поведения советских предприятий с извлечением «переходной ренты» по Полтеровичу; через множественные стратегии выживания в условиях нестабильности, слабого государства и острых бюджетных ограничений в 1990-е; формирование интегрированных структур, роста спроса на механизмы корпоративного управления в 2000-х гг. Но на каждом этапе сохранялись общие черты: множественность реакций в условиях институциональных трансформаций; тесное взаимодействие с государством регионального и федерального уровней; несовершенство института защиты собственности.

Данное исследование нацелено на анализ поведения российских промышленных фирм в среднесрочной перспективе (1995-2012 гг.) под влиянием институциональных условий ведения бизнеса, с учетом особенностей отдельных этапов эволюции российской экономики (восстановительный рост, расширение 
производства, финансово-экономический кризис). Предметом исследования является изучение влияния институциональных факторов, в том числе государственного регулирования, на устойчивость и формы проявления закрытого типа экономического поведения крупных российских предприятий.

Анализ особенностей функционирования предприятий в российской переходной экономике показывает, что предприятия сами порождают определенные деформации институтов, такие как сохранение взаимовыгодного рентоориентированного поведения государства и корпораций, стремление к созданию нерыночных механизмов защиты от конкуренции в отрасли.

Особенностями настоящего исследования являются:

1) содержание: по предмету — в сочетании анализа внешних институциональных рамок функционирования бизнеса и его поведенческих реакций и внутренних институтов, форм организации предприятий;

2) методология: при сопоставлении роли институциональных условий, их проявления в различных отраслях промышленности с учетом особенностей развития отраслей в глобальном контексте;

3) методика: по используемой информации - в обращении к сопоставлению многолетних микроэкономических данных (количественных и качественных) на 10-15-летнем горизонте для выявления особенностей институционального развития фирм на разных этапах становления рыночной экономики в России.

Основные результаты исследования в области теории предполагают развитие институциональной теории на основе комплексного анализа особенностей функционирования предприятий в российской переходной экономике, которые и сами порождают определенные деформации институтов; в области методологии определение качественных тенденций в поведении фирм путем создания множественного (сравнительного) кейса по трем российским корпорациям и сопоставления с ранее полученными результатами эмпирических исследований на среднесрочном интервале. 
Для решения поставленных задач в исследовании используются результаты изучения поведения российских корпораций, дополненные двумя кейсами по компаниям, чьи штаб-квартиры находятся в Свердловской области (ОАО «Свердловский инструментальный завод», ОАО «Екатеринубргская электросетевая компания»), дополненные экспертными мнениями, данными статистической и корпоративной отчетности компаний.

\section{Закрытый тип экономического поведения российских корпораций как реакция на институциональные трансформации экономики}

Одной из важных черт в поведении экономических субъектов в трансформационной экономике является распространение рентоориентированного поведения наравне с прибылеориентированным. Смена норм и правил функционирования и взаимодействия экономических агентов требует создания сравнительно недорогого механизма обеспечивающего их выполнение. В переходной экономике вырастает доля искусственных, сознательно формируемых институтов. Резко возрастает роль государства в период институциональных трансформаций. Высоки соблазны злоупотребления государством своими преимуществами, а выгоды добровольного выполнения обещаний и условий контрактов снижаются.

Основой взаимозависимости корпорации и государства в трансформационных экономиках является рентоориентированное поведение обоих, которое не связано с эффективностью бизнеса (государственная поддержка может оказываться как нерентабельным, так и прибыльным предприятиям) [2], но с институциональной неопределенностью [3; 4] и конкурентным давлением на рынках. Процессы глобализации на развивающихся рынках приводят к усилению конкуренции за привлечение капитала и инвестиций как со стороны отдельных фирм, так и территорий. Влияние региональных и муниципальных органов власти, отстаивающих собственные интересы (социальная стабильность, низкий уровень открытой безработицы, жизнеспособность жилищно-коммунальной и социальной инфраструктуры, рост налоговых поступлений), 
играют особую роль в реализации корпоративного контроля над корпорациями [5]. Органы власти используют для его реализации формальные механизмы воздействия на развитие предприятия (участие в собственности, участие в совете директоров, региональное законодательство) и неформальные (прямые указания, договоренности).

Рентоориентированное поведение фирм и государства в условиях слабости государственных институтов и механизмов рыночного регулирования позволяет прогнозировать возможные ключевые характеристики модели корпорации, а также направления развития модели.

Несмотря на увеличение мер по совершенствованию институциональной среды российской экономики, слабая защита прав собственности и неопределенность институтов до сих пор остается серьезной проблемой для стабильного развития бизнеса. Бюджетные ограничения компаний различных отраслей и институциональная неопределенность среды, стимулируют и создают условия для поиска механизмов защиты от конкурентного давления со стороны крупных компаний из других регионов или международных корпораций. Это порождает закрытость региональных рынков для вхождения новичков [6]. В условиях трансформационной экономики издержки на создание защитных механизмов могут оказаться ниже затрат на конкурентную борьбу и повышение эффективности компаний. Среди таких механизмов выделяют два:

- присоединение к крупным интегрированным структурам;

- создание сети отношений с властями на региональном уровне.

Механизмом защиты от конкуренции является система взаимоотношений крупного бизнеса и государства. В ряде работ [7; 8] показана роль государства в формировании большого бизнеса в России и сохранение тесных связей органов власти и бизнесгрупп как условие деятельности последних. На материалах случайной выборки из 98 уральских ОАО была обнаружена большая доля государства в управляющих компаниях холдингов, что может отражать две тенденции: сохранение за государством контроля над 
стратегически значимыми предприятиями и возможность использовать ресурсы успешного бизнеса в интересах регионов. В то же время рычаги воздействия на холдинги в руках региональных властей сокращаются, уступая место федеральной собственности [9].

В посткризисных условиях стремление российского крупного бизнеса к защите от конкуренции только усиливалось. Компании демонстрировали оппортунистическое поведение: вывод активов за рубеж, выплата дивидендов на фоне убыточной деятельности, лоббирование протекционизма и др. В связи с этим первостепенной задачей государства является создание стимулов к принятию эффективных решений на фирмах и в условиях прозрачных и единых для всех правил игры. Поэтому представляются важными шаги как в области поддержания конкуренции на товарных рынках, так и совершенствование институтов.

Итак, закрытость в экономическом поведении корпораций в условиях несовершенных институтов характеризуется:

1. Закрытостью структуры собственности и высокой концентрацией контроля в условиях слабой защиты прав собственности.

2. Закрытостью информации во внешнюю среду и несовершенством передачи информации внутри фирмы.

3. Поиском нерыночных механизмов снижения конкурентного давления на фирму, издержки, на создание которых ниже издержек по повышению конкурентоспособности. К таким механизмам относятся корпоративная интеграция и создание системы корпоративных отношений с государством на федеральном и региональном уровнях, в которых государство выступает как специфический стейкхолдер и участвует в системе обменов с компаниями.

\section{Множественный кейс «Закрытый тип экономического поведения уральских корпораций»}

Кейс 1. ОАО «Екатеринбургская электросетевая компания»

Основу электроэнергетики России составляют гидроэлектростанции (ГЭС), тепловые электростанции (ТЭС) и атомные электростанции (АЭС). При этом на долю тепловой генерацим приходится порядка 65,5 \% установленных мощностей по выработке 
электроэнергии. Электрические сети, магистральные и распределительные доставляют электроэнергию до потребителей. Сети связаны между собой трансформаторными подстанциями, преобразующими напряжение из высокого в низкое.

Гигантский энергохолдинг РАО «ЕЭС России», подконтрольный государству (за исключением объектов атомной энергетики они относились к ФГУП «Росэнергоатом»), имел территориальные подразделения (72 АО-энерго) по всей стране. Реформа отрасли была направлена на привлечение в отрасль частных инвестиций. Реформа РАО предполагала разделение бизнеса на производственную (электростанции), сетевую (сети по передаче энергии) и сбытовую части. Перегруппировка была необходима для создания конкурентных рынков в генерации и сбыте электроэнергии, но при этом государство оставило за собой монопольное право на услуги по передаче электроэнергии. Принцип конкурентного рынка заключается в том, что генерирующие компании, конкурируя между собой, позволяют сформироваться свободным рыночным ценам на электроэнергию. Однако тарифы на электроэнергию для населения, вне зависимости от степени либерализации оптового рынка, будут регулироваться государством.

Основными тенденциями развития отрасли являются:

1) рост цен на энергоресурсы, в первую очередь на газ;

2) сохранение системы перекрестного субсидирования внутри отрасли, что не стимулирует распространения энергосберегающих технологий и вложений в эффективность;

3) недостаточная конкуренция при выборе поставщиков энергии;

4) концентрация игроков на рынке из-за непоследовательной политики государства, поощряющей консолидацию активов в сетевом секторе;

5) рост тарифов на электроэнергию для юридических лиц (прежде всего для малого и среднего бизнеса) при зарегулированности цен для населения;

6) высокая доля резервных мощностей в отрасли, что приводит к удорожанию энергии; 
7) низкую надежность системы энергоснабжения (основным приоритетом в энергетической политике является экономический рост, безопасность и дешевизна энергии стоят на втором и третьем месте, четвертое занимает экология) [10].

Таким образом, несмотря на проводимую реформу, в отрасли сохраняется низкая конкуренция и существенное вмешательство государства, которое действует по принципу «ручного управления» важнейшей инфраструктурной отраслью.

Отметим, что основными характеристиками отрасли, влияющими на формы проявлений экономического поведения компании, являются территориальная структура отраслевого хозяйства, жестко фиксирующая привязку предприятий к конкретным обслуживаемым территориям; политические риски и ручное управление со стороны государства; тарифное регулирование в совокупности с перекрестным субсидированием, высокой долей резервных мощностей и неадекватным переходом на концепцию тарифообразования по доходности инвестированного капитала приводит к завышению тарифов; низкую надежность системы энергоснабжения (основным приоритетом в энергетической политике является экономический рост, безопасность и дешевизна энергии стоят на втором и третьем месте, четвертое занимает экология); рост цен на энергоресурсы, в первую очередь на газ; недостаточная конкуренция в отрасли как при выборе поставщиков энергии, так и из-за концентрация игроков на рынке из-за непоследовательной политики государства, поощряющей консолидацию активов в сетевом секторе.

ОАО «Екатеринбургская электросетевая компания» (ОАО ЕЭСК) - одна из крупнейших компаний Среднего Урала и крупнейшая электросетевая компания города Екатеринбурга, образована в 2001 г. на базе имущества Свердловских городских сетей и «Муниципальных электрических сетей». Основными видами деятельности общества являются передача электроэнергии и технологическое присоединение юридических и физических лиц к электрическим сетям на территории г. Екатеринбурга. Свою деятельность компания осуществляет в условиях естественной 
монополии, при которой государством регулируются тарифы на оказываемые услуги.

В 2011 г. выручка от реализации составила 4220 млн руб. (4 065 млн руб. от передачи электроэнергии, 128 млн руб. — от технологического подключения), что выше аналогичного показателя 2010 г. на 4 \%, а 2009 г. — на 27,5 \%. Рентабельность по прибыли от продаж составила в 2011 г. 30 \% за счет роста себестоимости услуг. Ключевые показатели эффективности общества в 2011 г., такие как рентабельность собственного капитала (ROE), обеспеченная денежным потоком (15,31 \% фактически против 10,09 установленных), суммарные потери электроэнергии к суммарному отпуску в сеть (10,63 \% против 11,15 \% установленных), реализация инвестиционной программы по срокам и стоимости (109 \% против 95 \% установленных за счет введения в строй трех подстанций и реконструкции двух подстанций), а также системные показатели нарушения электроснабжения и средней длительности перерывов электроснабжения обществом выполнены. ОАО ЕЭСК является одной из лидирующих в своей подотрасли компаний в России по уровню внедрения новых информационных технологий. Так, в мае 2011 г. завершилось внедрение автоматизированной системы управления финансово-хозяйственной деятельностью на базе SAP ERP 2005.

Спецификой системы управления компанией является оценка и предупреждение рисков во всех сферах своей деятельности. Среди отраслевых рисков компании основным является установление тарифов ниже экономически обоснованных, недополучение необходимого дохода за услуги по передаче электроэнергии и, как следствие, недостаток оборотных средств собственных источников для обновления основных фондов. Риски связаны с ограничением роста тарифов для конечных потребителей со стороны государства, неоднозначностью трактовки нормативно-правовых и методических документов по тарифообразованию, политические соображения при установлении тарифов. В качестве страновых и региональных рисков ЕЭСК видит продолжающуюся мировую рецессию, среди финансовых рисков - инфляцию. 
ОАО «ЕЭСК» принадлежит двум акционерам: ОАО «МРКС Урала» $(91,04$ \% акций) и ЕМУП «Муниципальные электрические сети» $(8,96$ \% акций). Акции общества не обращаются на фондовом рынке. Величина рыночной капитализации определена быть не может, однако может быть рассмотрен показатель величины чистых активов по состоянию на конец 2011 г. - 8 049,8 млн руб. Собственность высококонцентрированная, причем поддерживает контроль со стороны холдинга. Небогатая эмиссионная деятельность общества свелась к выпуску в 2007 г. купонных облигаций сроком погашения 5 лет. Соображения безопасности в широком смысле - и защита прав контроля за существующими акционерами, и повышенные требования к технологической безопасности в отрасли - привели к закрытости структуры собственности компании.

Вставка 1. Выдержка из интервью эксперта 1 (2013 г.): «У ЕЭСК был выпуск облигаций 25.01.2007 года. 1 миллион бумаг номиналом каждая в 1 mыс. руб. в 2010 году облигаџии были погашены. Попытки со стороны ЕЭСК провести дополнительную эмиссию акций были, но остановились еще до вынесения на обсуждение совета директоров, потому что акиионеры на сегодня боятся прихода новых собственников. Неизвестно, как они себя поведут. Условия работы в отрасли сейчас очень непростые. Отрасль очень нестабильна. В России все привыкли, что электроэнергия должна быть дешевой. Поэтому низкие тарифы на электроэнергию сегодня - это политический вопрос. Никаких рыночных механизмов цеенообразования нет. В этих условиях пускать кого-то, кто не работал раньше в отрасли, очень опасно».

Закрытость структуры собственности поддерживается выбором ориентированных на контроль источников финансирования инвестиций: амортизация и кредиты.

Вставка 2. Выдержка из интервью эксперта 1 (2013г.): «Основным источником финансирования инвестиционной деятельности для ЕЭСК являются кредитные ресурсы и амортизачионные отчисления, плюс плата за техприсоединение. 
Переход всех на RAB-регулирование - новый метод формирования тарифа, позволяет привлекать деньги в развитие сетей. $B$ тарифе на передачу энергии, помимо фактических затрат компании, учитываются суммы, обеспечивающие возврат средств вложенных в сети, а также некий процент дохода для инвестора, вложивщего эти средства».

В ЕЭСК сформирована упрощенная (по сравнению с положениями кодекса корпоративного поведения) система органов управления и контроля: общее собрание акционеров, совет директоров, директор и ревизионная комиссия. При этом директор и совет директоров имеют большую независимость от акционеров, чем это предписывается кодексом.

В состав совета директоров входит 9 человек: 5 директоров, в том числе председатель совета директоров - представители главного собственника «МРКС Урала»; директор ОАО ЕЭСК, представитель $3 \mathrm{AO}$ «КЭС», имеющего в своих активах дивизион «Генерация Урала», представитель администрации города Екатеринбурга по вопросам ЖКХ. Реальная независимость директоров отсутствует.

В компании однозначно работает модель «главный акционер осуществляет владельческий контроль напрямую, минуя совет директоров, независимо от своего членства в составе совета».

Требования безопасности в электроэнергетике заставляют руководство общества обращать особое внимание на сохранение квалифицированной рабочей силы, экологию и социальную ответственность бизнеса, которая выражается не только в специальных программах для работников ЕЭСК, но и готовности в критических ситуациях обслужить объекты, не находящиеся на обслуживании у компании по просьбам администрации города для сохранения и поддержания отношений с муниципальной властью.

Вставка 3. Выдержка из интервью эксперта 2 (2013 г.): «Несмотря на то, что городу как акционеру принадлежит меньше $10 \%$ акиий, в совет директоров все равно входит один директор от администрачии Екатеринбурга. Мы прекрасно понимаем, что никаких решений один директор провести не сможет, но мы 16 
должны считаться с властью. Во-первых, мы понимаем сочиальное значений электросетей как инфраструктурного объекта для города. И поэтому мы должны работать с администрацией Екатеринбурга в паре. Во-вторых, мы работаем на территории муниципального образования, а чтобь вести ряд работ, нам часто нужна помощьь города в согласовании различных вопросов, поэтому мы рассчитываем в ответ на помощьь нам города, на возможность использовать административный ресурс. Личные отношения в работе с городом гораздо важнее, чем корпоративное управление».

Компания демонстрирует тип поведения инсайдерской корпорации с концентрированным контролем, смешанным финансированием и вмешательством региональных властей в корпоративное управление. Кроме того, личные отношения с местными органами власти позволяют компании сохранять доминирующее положение на рынке при условии, что существуют также конкурирующие компании. На рынке города Екатеринбурга ЕЭСК занимают первое место по объемам полезного отпуска электроэнергии (5 349,4 млн кВт-ч), что больше совокупного отпуска всех конкурентов в 6,6 раза. Пять из восьми конкурентов являются непрофильными и выполняют работы для внутренних нужд предприятий. ЕЭСК стремится всеми доступными механизмами удержать доминирующее положение на рынке за счет:

1) рыночных механизмов: развитие мощностей (из интервью: «Всего же ЕЭСК имеет 60 у. е. передаюших мощностей, кроме того, в аренде 5 mыс. у.е. И мы стараемся расширять мощности, вводим постоянно в строй новые подстанциии»);

2) нерыночных механизмов: построение сети отношений с местными органами власти, которые также позволяют получать бесплатный доступ к «бесхозным сетям», что расширяет мощности предприятия.

Важной чертой экономического поведения является отсутствие реальных механизмов конкуренции в отрасли. Среди приведенных причин низкой конкуренции, отмеченной экспертами 
(приводится в начале кейса), представители компании отмечают эффект «ручного управления», регулирование тарифов и специфическую структуру отрасли.

Вставка 4. Выдержка из интервью эксперта 2 (2013 г.): «При реформировании РАО ЕЭС сделали ошибку, разделив собственность между генерирующими, сетевыми и сбытовыми компаниями. Конкуренция сбытовиков сейчас на рынке электроэнергии невозможна из-за ограничения по тарифу. На сегодня инвестиционная составляющая в тарифе УЭСК равна О. Все упирается в политику и менталитет российских людей: все хотят дешевую электроэнергию. Все претензии по неплатежам аккумулируются сегодня в “Екатеринбургэнергосбыт”. По Постановлению Правительства РФ № 442 у сетевиков и сбытовиком очень мало рычагов влияния на неплательщиков».

Информационная прозрачность компании неоднозначна. При том что компания формирует достаточно полный и квалифицированный годовой отчет с приложениями и нефинансовой отчетностью, однако в первую очередь это направлено на создание позитивного имиджа у местного сообщества, органов власти и холдинга, нежели чем направлено на инвесторов. При том что сайт компании информативен и регулярно обновляет информацию, сам топ-менеджмент считает компанию непрозрачной.

Из 78 положений кодекса корпоративного поведения обществом в 2011 г. соблюдалось 29 положений, частично соблюдалось 9, не соблюдалось 40. Наиболее полно соблюдаются положения об общем собрании акционеров. Отсутствие в совете директоров комитетов и положение об избрании директора общества советом директоров вместо общего собрания акционеров приводит к низкой доле соблюденных положений по совету директоров. Отсутствие правления и широкие права директора общества сокращают число соблюдаемых пунктов в разделе «Исполнительные органы». Несмотря на отсутствие принятой дивидендной политики, дивидендные выплаты ЕЭСК относительно стабильны. За последние три отчетных года (2008-2010 гг.) дивиденды составили 1,1, 1,7, 1,4 \% чистой прибыли по отчетным годам соответственно. 


\section{Кейс 2. ОАО «Свердловский инструментальный завод»}

В настоящее время в Российской Федерации металло- и дереворежущий инструмент выпускается на 25 специализированных предприятиях (Белгородский ИЗ, Волгоградский ИЗ, Высокогорский экспериментально-инструментальный завод (Нижний Тагил), Московский ИЗ, СИЗ и др.) и ряде частных фирм и цехов машиностроительных предприятий. В 2010 г. на специализированных заводах было произведено инструмента на $32 \%$ от уровня 1990 г. Предприятия инструментальной отрасли производят основную часть стандартного инструмента, применяемого в промышленности (свыше 350 ГОСТов на инструмент). Кроме специализированных заводов, производство инструмента осуществляют некоторые машиностроительные предприятия, в частности Ивановский завод тяжелого станкостроения (ОАО «ИЗТС»), новые предприятия, к которым можно отнести «Пумори-инструмент» (Екатеринбург), ЗАО «Винт» (Ярославль).

Хроническое кризисное состояние специализированных инструментальных заводов обусловлено несколькими основными факторами: отсутствие последовательной государственной политики; старение квалифицированных кадров; удорожание исходного сырья - вольфрама; падение спроса на инструмент у находящегося в кризисе машиностроения и оборонного комплекса. Затяжное кризисное состояние дел в отрасли несомненно является важнейшим фактором внешней среды предприятий.

ОАО «Свердловский инструментальный завод» - производитель сложнорежущего инструмента - создано путем акционирования предприятия, образованного еще в 1941 г., . С момента создания и вплоть до 1995 г. завод находился на грани банкротства. В 2004 г. на паритетных началах ОАО «СИЗ» и ООО «Пумориинжиниринг» образовали Уральскую машиностроительную корпорацию «Пумори-СИЗ». (Корпорация «Пумори-СИЗ» образована в паритете 50/50 с турбомоторным заводом.) В 2010 г. начался совместный раздел имущества собственниками УМК «ПумориСИЗ», который закончился тем, что в 2011 г. ОАО «Свердловский инструментальный завод» стал самостоятельным предприятием. 
На сегодня корпорация «Пумори» состоит из 10 предприятий в Екатеринбурге, Перми, Санкт-Петербурге и Казани, три из которых производят оборудование и инструмент, остальные подразделения специализируются на поставках и инжиниринге.

Распад объединенной компании «Пумори-СИЗ» генеральный директор А. В. Луговцов объясняет ошибками в организации управления: “Создание корпорации “Пумори-СИЗ” было попыткой укрепить позищии инструментальных предприятий, но при создании была допущена серьезная ошибка. Нельзя было допускать до управления функииональных специалистов. Нельзя собственнику уходить далеко от управления заводом, если он хочет его сохранить, сохранить оборудование, технологии, кадры. Мы сейчас производим инструменты для производства шестерен. А они нужны практически везде».

На СИЗе реализуется жесткая линейная структура управления, которая, по мнению генерального директора, является единственно оправданной.

Вставка 5. Выдержка из интервью эксперта 3 (2013 г.). «У нас на СИЗе создана исключительная структура управления. Мы впервые ввели должность исполнительного директора. Одновременно он является главным инженером завода. Исполнительный директор уполномочен единолично принимать решения по мероприятиям, расходы на которые не превышают 100000 руб. В ведении генерального директора находятся мероприятия, сумма расходов на которые не превышает $25 \%$ балансовой стоимости имущества предприятия, в ведении совета директоров - от 25 до $50 \%$ балансовой стоимости имущцества завода, по остальным расходам на мероприятия решение принимает общее собрание акиионеров. В остальном организационная структура завода является функциональной».

За последние пять лет число инструментальных заводов в УрФО сократилось с 33 до 5. Сам СИЗ также на сегодня является средним по размеру предприятием со среднесписочной численностью персонала в 2011 г. 262 человека (средняя зарплата 22155 руб в год), выручкой в 226,772 млн руб. При этом доход 
обществу обеспечивают, помимо производства инструмента (55 \% оборота за 2011 г.), аренда помещений (27 \% годового оборота за 2011 г., территория завода находится в районе, прилегающем к центральной части города Екатеринбурга), производство тепловой энергии (9 \% годового оборота за 2011 г.), общественное питание и прочие услуги. В качестве перспектив развития общество видит рост продаж инструмента и доходов от аренды.

Дивиденды обществом не начисляются и не выплачиваются в течение последних трех лет. Деятельность по производству инструмента является убыточной, аренда помещений перекрывает убытки по производственной деятельности.

Структура собственности на заводе концентрированная и сложная для принятия решений.

Вставка 6. Выдержка из интервью эксперта 3 (2013г.): «В структуре собственности отсутствуют государство, иностранные собственники, институцииональные инвесторы и банки. На сегодня собственность завода концентрированная. Структура собственности очень не простая для управления. $78 \%$ уставного капитала находится у двух закрытых акиионерных обществ, которые в конечном счете 50/50 принадлежат двум физическим лицам. И два равновластных собственника определяют стратегию и политику предприятия. Мы на сегодня единственный, сохранивший полную номенклатуру инструментальный завод, в Екатеринбурге».

По сути, акционерное общество является закрытым, так как акции никогда не обращались на фондовом рынке. Даже в период наличия миноритарных акционеров акции скупались напрямую высшим руководством завода. В состав совета директоров ОАО «СИЗ» после разделения имущества с корпорацией «Пумори-СИЗ» входят 8 человек, из них 5 исполнительных директоров, включая двоих владельцев завода, из оставшихся троих директоров - двое являются детьми основных акционеров. Включение сына и дочери акционеров компании в состав совета объясняется собственниками как желание привлечь второе поколение семей к управлению заводом и продолжению стратегии сохранения завода как производственной единицы. 
В компании совмещаются интересы менеджмента и акционеров. Подконтрольный топ-менеджменту и одновременно основным акционерам совет ярко иллюстрируется следующей цитатой: «В нашем случае Совет директоров состоит из акционеров, так что независимости нет, а независимый директор есть, но его наличие скорее связано с выполнением требований регулятора. Независимые директора нужны в реальности для крупных торгуемьхх компаний».

Информационная закрытость завода: на сайте последний помещен последний годовой отчет за 2009 г., а основная информация адресована потребителям продукции, объясняется генеральным директором тем, что излишняя информация повредит и без того низкой рыночной оценке завода, а раскрывать информацию для инвесторов публично, если внешних акционеров у завода нет и появиться они на «семейном предприятии» не могут, неразумно. Привлечение сторонних инвесторов не предполагается, так как у сегодняшних владельцев завода нет уверенности в том, что кто-то другой будет заинтересован в продолжении производственной деятельности завода, любой сторонний инвестор будет заинтересован в использовании земельного участка завода и прекращении нерентабельного профильного производства.

\section{Результаты и выводы}

На основании проведенного исследования экономического поведения российских корпораций в условиях институциональных трансформаций были сделаны следующие выводы и получены основные результаты в соответствии с выдвинутыми исследовательскими гипотезами.

1. Закрытый тип поведения российских корпораџий в условиях продолжающихся институциональных трансформаций сохраняется благодаря высоким агентским издержкам и несовершенству институтов, а также является типом приспособления корпораций к сложившейся институциональной среде.

2. Основными чертами закрытого типа экономического поведения фирм являются закрытость информации о работе корпорации 
(информационная асимметрия); закрытость состава собственников, приводящая к высоким барьерам входа/выхода в состав собственников; стремление к закрытости рынков путем создания высоких отраслевых барьеров. Закрытость сокращает возможности роста компаний, но снижает предпринимательские риски.

3. Спецификация и защита прав собственности - институциональные условия возникновения конкуренции, поскольку стимулы к росту фирмы и получению прибыли действенны только тогда, когда есть уверенность в том, что прибыль достанется тем, кто затратил усилия на победу в конкурентной борьбе. Высокая вероятность захвата предпринимательской ренты повышает отдачу от поведения фирм, ориентированных на закрытость.

Специфические механизмы защиты от конкурентного давления на рынках с затратами меньшими, чем затраты на модернизацию и реструктуризацию фирмы являются корпоративная интеграция и система обменов с государством на региональном и федеральном уровнях.

Меры государственного регулирования, направленные на повышение информационной открытости компаний, оказываются малоэффективными. Одним из механизмов стимулирования открытости компании может служить политика стимулирования конкуренции (усиление конкурентного давления на фирмы) на товарных рынках со стороны глобальных операторов рынка посредством включения России в процессы глобализации.

4. Закрытость структуры собственности и высокая концентрация контроля распространены в крупном бизнесе. Инвестиционные возможности компании подталкивают к привлечению финансирования с фондовых рынков, что снижает барьеры входа в собственность для внешних инвесторов. Стремление к закрытости структуры собственности зависит от сочетания уровня конкурентного давления на компанию, потенциала расширения производства в отрасли в целом, финансового состояния компании и изначальной структуры собственности.

5. Информационная закрытость зависит от состояния конкуренции в отрасли, потребности во внешнем финансировании 
и действий регулятора. Внутри холдинговых структур раскрытие информации дифференцируется в зависимости от статуса компании в холдинге и ее функционала в технологической цепи.

6. Государство по-прежнему играет решающую роль в создании условий конкуренции для компаний в различных отраслях. Издержки на специфические механизмы защиты от конкуренции продолжают оставаться ниже рыночных.

\section{Список питературы}

1. Долгопятова Т. Г. Российский бизнес 20 лет спустя: путь от социалистического предприятия к рыночной фирме / Т. Г. Долгопятова, И. Ивасаки, А. А. Яковлев // Мир России. 2009. № 4. С. 89-114.

2. Структурные изменения в российской промышленности / под ред. Е. Г. Ясина. М. : Изд. дом ГУ-ВШЭ, 2004. 260 с. 3. Яковлев А. А. Почему в России возможен безрисковый уход от налогов? / А. А. Яковлев // Вопросы экономики. 2000. № 11. С. 134-152.

4. Johnson S. The Unofficial Economy in Transition / S. Johnson, D. Kaufman, A. Shleifer // Brooking Papers on Economic Activity. 1997. № 2. P. 159-239.

5. Долгопятова Т. Г. Модели и механизмы корпоративного контроля в российской промышленности (опыт эмпирического исследования) / Т. Г. Долгопятова // Вопросы экономики. 2001. № 5. С. 46-60.

6. Yakovlev A. State-Business Relation in Russian Regions: What Has Changed in 2000-s? / A. Yakovlev // Discussion Paper. 10th EACES bi-annual conference «Patterns of transition and new approaches to comparative economics». Moscow. 28-30 August 2008. European Association for Comparative Economic Studies, HSE, 2008.

7. Паппэ Я. Ш. Российский крупный бизнес как экономический феномен: специфические черты, модели его организации / Я. Ш. Паппэ // Проблемы прогнозирования. 2002. № 2. С. 83-97.

8. Яковлев A. A. Российская корпорация и региональные власти: эволюция модели взаимоотношений / А. А. Яковлев // Вопросы экономики. 2007. № 1. С. 124-139.

9. Ружанская Л. С. Корпоративный контроль в российских компаниях: основные модели / Л. С. Ружанская // Журнал экономической теории. 2008. № 2. С. 151-167.

10. Прогноз развития энергетики мира и России до 2035 года. М. : ИНЭИ РАН, 2012 [Электронный ресурс]. URL: http://gissee.ru 


\section{§ 2. Российские предприятия в современных условиях: влияние внешних и внутренних угроз}

Успешное развитие экономических субъектов в любое время определяется влиянием внешних и внутренних факторов. Факторы, которые бы стимулировали и оказывали поддержку предприятиям в их предпринимательской деятельности, можно охарактеризовать как дружеские, в то время как факторы, оказывающие отрицательное влияние и сдерживающие предпринимательскую активность организаций, и даже прекращающие ее, следует рассматривать в виде угроз. При этом влияние внешних угроз существенно превосходит по своей мощи влияние внутренних.

Какие же угрозы наиболее актуальны на сегодняшний день для современного состояния экономики и ее предпринимательского сектора?

Комитетом по Восточной Европе в конце декабря 2014 г. был проведен опрос российских компаний практически всех отраслей промышленности. Примерно 17 \% опрошенных приходится на машиностроение, $10 \%$ — на сферу услуг, на автомобилестроение, сельское хозяйство и пищевую промышленность - по 8 \%, на строительство, транспорт и логистику - по 7 \%. Как далее явствует из проведенного опроса, 30 \% опрошенных заявили, что местом постоянного нахождения является Москва, 11 \% зарегистрированы в Санкт-Петербурге. Следует отметить, что на данных компаниях с годовым оборотом 19 млрд евро занято в Российской Федерации более 71000 сотрудников.

Экономические санкции и конъюнктурные колебания, как отмечают российские компании, существенно изменили масштабы хозяйственной деятельности. Например, 91 \% опрошенных российских производителей уверенно констатировали ухудшение делового климата в стране. Соответственно, и их рациональные ожидания на 2015 г. носят также достаточно четко выраженный негативный характер.

Большое количество российских предприятий, а именно 71 \% от числа попавших в выборку, отметили, что были существенно 
затронуты конфликтом на Украине и его последствиями, связанными с упавшим спросом на производимую продукцию и проблемами с финансированием.

Большую угрозу для экономических субъектов продолжает представлять бюрократия и коррупция на российском рынке. Не последнюю роль на негативное экономическое положение многих организаций оказывают имеющиеся в национальной экономике протекционисткие барьеры.

Однако если более точно раскрыть основные причины экономической нестабильности в российской экономике, которые угрожают развитию российских предприятий, то картина будет выглядеть следующим образом: для 30 \% российских предприятий главным фактором ухудшающегося экономического положения является существенное падение цен на нефть, в западных санкциях угрозу видят 25 \% предприятий, для $1 / 5$ недостаточность или отсутствие структурных реформ в экономике представляет наибольшую опасность, как и отсутствие возможностей для диверсификации для $15 \%$ российских предприятий. Конечно, предприятиями назывались и многие другие причины нестабильного экономического положения, как, например, уже названные выше коррупция, протекционизм в экономике, но и отмечалось отсутствие развитого и устойчивого малого и среднего предпринимательства (рис. 1).

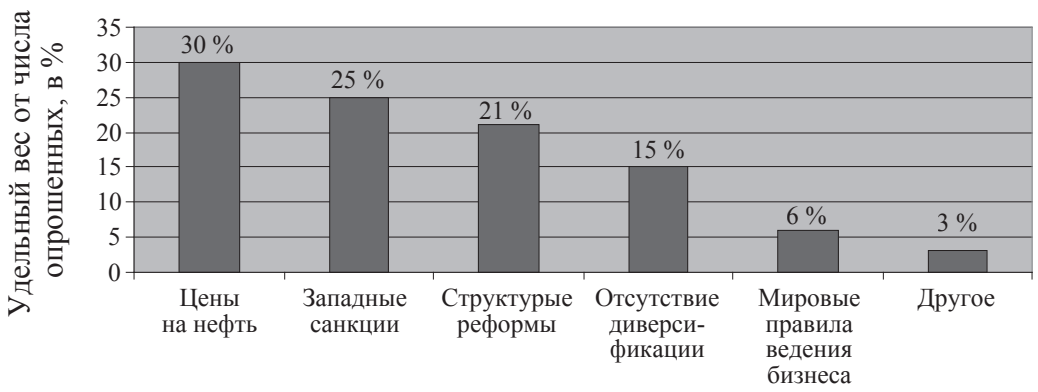

Рис. 1. Барьеры развития российских предприятий в услових кризиса 
Даже для флагманов российской экономики в нефтедобывающем секторе ситуация постепенно становится неприятной. И хотя в 2014 г. было добыто рекордное количество нефти, существуют опасения, что тенденция может стать отрицательной. Так, например, отечественный энергетический гигант Газпром добыл в 2014 г. на 9 \% меньше природного газа, чем в 2013 г. Специалисты отмечают, что это так мало, как никогда ранее с момента его основания.

Какие же внешние факторы будут преобладающе влиять на российскую экономику в 2015 г.? Преобладающую угрозу будет продолжать нести цена на нефть. Если цена на нее не будет продолжать падение и дальше и закрепится на определенном уровне, то, как полагают многие отечественные и зарубежные специалисты, это станет одним из первых признаков начинающейся стабилизации в экономике.

В качестве положительного внутреннего фактора следует отметить принятый на 2015 г. план по поддержке 190 системообразующих российских предприятий. В первом квартале 2015 г. на эти цели должно было быть выделено 22 млрд руб.

Очевидно, сохранится и даже усилится положительная тенденция развития в сельском хозяйстве и пищевой промышленности. Предприятия сельскохозяйственной отрасли и пищевой промышленности выиграли от введенных санкций через запрет на сельскохозяйственные товары из стран Европейского союза, Норвегии, Соединенных Штатов Америки, Канады и Австралии, который вступил в силу с 6 августа 2014 г.

Свою положительную роль сыграло и падение курса отечественной валюты: многие российские предприятия и домашние хозяйства, чтобы избежать обесценения своих накоплений, начали активно вкладывать денежные средства в материальные активы, в том числе в промышленную продукцию. По этой причине промышленное производство в декабре 2014 г. выросло на 3,9 \% по сравнению с соответствующим периодом 2013 г.

Как полагают специалисты, в том числе и из опрошенных компаний, в 2015 г. наиболее сильный экономический рост ожидается 
в сельском хозяйстве и пищевой промышленности. Также очень хорошие перспективы прогнозируются для компаний, работающих в сфере информации и телекоммуникаций, в области минеральных ресурсов, логистики и энергетики. Существенное экономическое ослабление ожидается лишь в строительстве и автомобилестроении.

\section{§ 3. Дилемма профсоюзов в переговорном процессе работников и работодателей: выбор между занятостью и оплатой труда?}

В настоящее время общепризнано, что поведение российских предприятий детерминировано изменившейся институциональной и экономической средой их обитания, трансформацией внутренней структуры, усложнением связей, взаимоотношений и интересов участников. Среди прочих условием их успешного развития становится построение эффективной системы отношений между работниками и работодателями, объединяющей различные организационные, управленческие, социальные, материальные и иные практики, правила и институциональные конструкции, которые конституируют данные отношения и могут достраиваться их коллективными и индивидуальными участниками. Регулирующая роль государства в этом вопросе, доминировавшего длительное время, оказалось сведенной к минимуму, и работодатели постепенно приобрели возможности выбора различных по конфигурации отношений «работник - работодатель» на предприятиях. Обобщение опыта российских и зарубежных компаний свидетельствует о стремительном распространении практики индивидуализированных отношений между работником и работодателем, где большинство вопросов зарплатообразования и применения гибких форм занятости становятся предметом реального переговорного процесса между участниками предприятия - работодателем, профсоюзом и работниками. Это актуализирует исследования значение, функций и роли профсоюза как институционализированного посредника в отношениях работников и работодателей на уровне 
отдельного предприятиях. Дискуссии относительно профсоюзного движения и развития производственной демократии в общественных и политических кругах как в России, так и в других странах идут активные и бурные, но вместе с тем они по большей части носят характер риторики, нежели чем реального изучения феномена юнионизации работников.

Резкое сокращение членства профсоюзов в последнее десятилетие во всем мире, детерминированное демографическими переменами, изменением в отраслевой и региональной структуре занятости, усилением конкуренции и противодействием работодателей, приводит к снижению степени охвата работников профсоюзным движением так называемой «плотности» профсоюзного движения («union density») и ставит вопросы о дальнейшей судьбе существования традиционных профсоюзов и перспективах развития процессов юнионизации работников в целом.

Учитывая отмеченные обстоятельства, нами был осуществлен расширенный поиск исследовательских подходов к изучению современных тенденций юнионизации работников и проведена оценка факторов, влияющих на изменение численности работников и средней заработной платы на предприятиях с разной степенью активности профсоюзов в переговорном процессе в посткризисный период, выявившая различные эмпирические профили их поведения на примере группы уральских промышленных компаний.

Систематизация теоретических воззрений на феномен юнионизации работников и активности профсоюзов в переговорном процессе из различных научных перспектив позволила сделать следующие выводы.

На протяжении последних двух столетий институционализированными формами юнионизации работников и производственной демократии являются их объединение в традиционные профессиональные союзы (профсоюзы) и ассоциации, поэтому их деятельность стала предметным полем теории индустриальных отношений, изучающей организованные взаимодействия труда и капитала, а также систему институций, укорененных 
в экономической, социальной и культурной ткани общества. В рамках данной теории рассматриваются две различные по содержанию и характеру страновые модели отношений между участниками национальных рынков труда.

Британская (американская) модель индустриальных отношений (децентрализованная система), в рамках которой доминируют традиции волюнтаризма [1] и «акторы индустриальных отношений - работодатели, профсоюзы, и государство - отдают предпочтение волюнтаристски организованному и независимому регулированию отношений занятости, а также "не-юридическому" подходу к коллективным переговорам» [2]. В качестве особенностей данной модели отмечается также «профсоюзный плюрализм» [3], неформальная переговорная власть цеховых представителей работников, антипрофсоюзная политика государства и т. д.

В свою очередь, немецкая модель признает сосуществование конкурентных рынков труда с государственным регулированием отношений занятости, наличие вертикально и горизонтально фрагментированной суверенности отдельных компаний, ограничивающей прямое вмешательство государства в их деятельность, признание роли ассоциаций и других юнионизированных форм объединения работников в регулировании институционализированных рынков, преобладание организационной культуры, опирающейся на коллективизм, профессиональную компетенцию, знания, дисциплину в качестве ключевых ценностей и основы дискреционной власти [4]. В основании данной модели лежат два фундаментальных принципа построения:

- свободные коллективные переговоры (отраслевые соглашения как результат переговоров профсоюзов с ассоциациями работодателей);

- участие наемных работников в управлении на всех организационных уровнях компании.

Рабочие советы, представляющие интересы рабочих в этом процессе, избираются демократическим путем всеми работниками предприятия и формально не зависят от профсоюзов [5]. Вместе с тем в последние десятилетия в результате воссоединения 
Германии и процессов европейской интеграции институциональная структура немецкой модели индустриальных отношений качественно трансформировалась, что нашло отражение в следующих основных трендах:

1) децентрализация переговорного процесса между участниками как смещение от коллективных переговоров на отраслевом и национальном (государственном) уровнях к индивидуальным переговорам на уровне отдельных предприятий;

2) дерегулирование как ослабление регулирующей функции профсоюзов в действующей модели отношений между работниками и работодателями;

3) дезорганизация как продолжающееся снижение организационного потенциала профсоюзов наемных работников и ассоциаций работодателей.

Согласно научной перспективе экономической теории труда, профсоюзное членство наемных работников рассматривается в рамках установления баланса «спроса — предложения» на рынке труда. Юнионизация (и наемных работников, и работодателей) рассматривается как детерминированная материальными выгодами, которые каждый индивид может получить от членства в профсоюзе или ассоциации (вероятность сохранения рабочего места, различия в оплате труда, прочие бенефиты, обладание дискреционной властью и т. д.). Теоретическому анализу поведения предприятий в области оплаты труда и занятости служат переговорные модели рынка труда на локальном уровне. Равновесная оплата труда в данных моделях зависит от влияния внешних и внутренних факторов институциональной среды, среди которых особая роль отводится переговорной силе вовлеченных в процесс сторон. Иными словами, каждая сторона переговорного процесса обладает определенной свободой выбора действий путем максимизации собственной функции полезности. При этом действия профсоюзов могут не соответствовать общим интересам работников и иметь самостоятельную политическую направленность (функции полезности профсоюза представлены как частные случаи функции Стоун Джери в случае рассмотрения их поведения как монополиста [6]). 
Для анализа переговорной силы сторон, вовлеченных в процесс определения оплаты труда и занятости, выделяются две группы моделей: модели о результатах переговоров и модели процесса переговоров [7]. Модели о результатах переговоров между участниками предприятия (модель Чемберлена и другие) позволяют определить силу убеждения профсоюза (работодателя) как отношение издержек работодателя (профсоюза) по несогласию с профсоюзом (работодателем) к издержкам при согласии. Определение издержек сторон при переговорах отражено в модели забастовок (модель Хикса [8]), где целью является прежде всего достижение желаемого уровня оплаты труда работников и забастовка возможна только в условиях асимметрии информации: руководство профсоюза не доводит до сведения работников уровень оплаты труда, приемлемый для работодателя и может либо убедить работников согласиться с таким уровнем, либо пойти на забастовку, приобретая политическую репутацию. Модели процесса переговоров (модель двухсекторного рынка труда) позволяют анализировать влияние профсоюзов на разницу в оплате труда между юнионизированными работниками и работниками, не состоящими в профсоюзе.

Институциональная экономика рассматривает профсоюзы как один из базовых институтов, регулирующих отношения на рынке труда и создающих для других участников отрицательные и положительные внешние эффекты (экстерналии). Отрицательные экстерналии связаны с дополнительными издержками от проведения забастовок, ограничением мобильности и жесткостью механизма оплаты труда, в конечном итоге способствующих росту безработицы, снижению прибыли и инвестиций в специфические активы. В свою очередь положительные экстерналии видятся в том, что профсоюз как институт регулирования взаимоотношений работников и работодателей способен привести к сокращению текучести, повышению дисциплины и снижению издержек от оппортунистического поведения работников. О. Уильямсон выделяет две 
функции профсоюзов, способствующих росту эффективности их деятельности [9]:

- представительская функция, позволяющая сторонам переговорного процесса заключать и реализовывать предпочитаемые трудовые соглашения;

- управленческая функция, создающая предпосылки для непрерывности отношений занятости и найма работников.

Из перспективы поведенческой экономики добровольная включенность работника в юнионизированную структуру, помимо экономических выгод, свидетельствует о стремлении приобрести им от членства, в частности в профсоюзе (помимо прочего), «репутационную» ренту. Подход к исследованию юнионизации работников с позиций теории рационального выбора интерпретирует ее как сопоставление «цены» членства в профсоюзе (вступительный взнос, ежемесячные взносы, ценность времени, которое необходимо для профсоюзной работы) и выгод от членства в профсоюзе, а интеракционисткий подход фокусирует внимание на групповой организационной культуре и рассматривает решение работника вступить в профсоюз под влиянием личных установок, социального контекста.

Особое внимание уделяется исследованию так называемой проблемы «безбилетника» (problem of «free-riding»), с которой сталкиваются профсоюзы крупных компаний большинства промышленно развитых стран. Суть данной проблемы состоит в том, что усилия отдельных работников по защите интересов всех членов профсоюзов могут быть существенно выше, чем других недобросовестных участников, а выгоды существенно ниже, что влияет на выбор типа профсоюзного членства - обязательное либо добровольное [10] и предопределяет открытый («ореn shop») либо закрытый («closed shop») типы профсоюзов.

Историческая перспектива исследования производственной демократии и юнионизации работников рассматривает концепцию социального партнерства, пришедшую на смену концепции классовой борьбы. Однако стоит отметить, что большинство работ по данной проблематике носит дескриптивный характер, 
где теоретический анализ причин, условий, последствий социального партнерства весьма ограничен, а эмпирические оценки (преимущественно социологические) касаются содержания и условий разработки коллективных договоров и отраслевых соглашений. В частности, типология социального партнерства в страновом разрезе представлена следующими моделями:

- патерналистическая (Финляндия, Швеция, Бельгия, Норвегия, Нидерланды), подразумевающая активное участие государства в регулировании трудовых отношений между работниками и работодателями, включая все уровня социального партнерства: национальный, отраслевой и уровень предприятий;

- плюралистическая (США, Канада, Япония), где в качестве базового уровня взаимодействия между работниками, работодателями и профсоюзами выступает отдельная предпринимательская организация;

- регулятивная (Германия, Австрия, Франция) включает проведение переговоров между профсоюзами и ассоциациями работодателей на разных уровнях.

Российские публикации, посвященные современным тенденциям юнионизации работников, свидетельствуют о преимущественном изучении различных аспектов концепции социальнотрудовых отношений. Согласно данной концепции институты представительства коллективных интересов наемных работников - профсоюзы - возникают тогда, когда появляется необходимость сохранить или улучшить условия индивидуальных трудовых контрактов, имеются объективные и субъективные условия для объединения наемных работников одного предприятия, профессии, региона, отрасли для отстаивания своих прав или достижений общих целей. Говоря о месте профсоюзов в переговорном процессе, подчеркивается, что превращение работников в активные субъекты социально-трудовых отношений совпадает с процессом появления реальных, подлинных профсоюзов. Основное различие, таким образом, проводится между прежними и новыми формами 34 
юнионизации работников, рассматриваются трудности существования и возможности развития каждого из этих вариантов.

Еще одним аналитическим контекстом исследования юнионизации работников является теория рабочего движения как общественной силы - движение за трудовые права наемных работников, где профсоюзы рассматриваются не просто как его неотъемлемая часть, но как организующее начало. Роль профсоюзов определяется значением наемного труда в обществе, а профсоюзы видятся выразителями интересов большинства граждан. Из перспективы рабочего движения базовой характеристикой профсоюзов предстает степень их «боевитости», способности защищать интересы работников наемного труда в противостоянии с работодателем или государством, что предопределяет различные виды российских профсоюзов [11]:

1) альтернативные профсоюзы - новые профсоюзные объединения работников наемного труда, отстаивающие их интересы в отношениях с работодателями (прежде всего внутри предприятий) и обычно не допускающие работодателей в свой состав;

2) традиционные профсоюзы - прежние профсоюзные объединения, постепенно превращающиеся в настоящие тредюнионы, отражающие интересы наемных работников при условии совпадения с интересами администрации предприятий и допускающих членство высших менеджеров-работодателей (интересы профсоюзов и работодателей в этом случае противопоставляются интересам государства);

3) псевдопрофсоюзы - группы прежних профсоюзов, которые, продолжая считать себя профсоюзами, фактически становятся частью менеджмента предприятий;

4) называющие себя профсоюзами самоорганизованные группы мелких предпринимателей, торговцев, кустарейкооператоров.

Характеризуя поле деятельности профсоюзов в новейшей истории России из перспективы рабочего движения, исследователи выделяют следующие юнионизированные формы объединения 
работников: «настоящие» профсоюзы, защищающие интересы наемных работников; «не настоящие» профсоюзы, основной функцией для которых является распределительная, и сблизившиеся по своим рентным интересам с менеджментом предприятий.

Проблемы бюрократизации профсоюзных организаций как системное свойство современного российского трейд-юнионизма отмечались в ряде работ [12], где в качестве причин, способствующих бюрократизации, указывается пассивность рядовых членов, снижение роли лидерских функций профсоюза, а также сокращение коллективных действий, основанных на солидарной активности рабочих.

Таким образом, по нашему мнению, исследовательская проблема состоит в недостатке актуальных теоретических знаний и эмпирических данных о влиянии профсоюзов на выбор поведения предприятий по вопросам занятости и оплаты труда, что и определило цель данной работы. Методология исследования опиралась на выбор адекватного поставленной задаче инструментария. В частности, для проверки выдвинутых гипотез был использован эконометрический анализ взаимосвязей между показателями, характеризующими степень юнионизации работников (вовлеченность работников в профсоюзы, оценка переговорной силы участников предприятий, характеристика личных качеств профсоюзного лидера) и показателями, отражающими поведение предприятий в сфере занятости и оплаты труда. Статистическая обработка эмпирических данных и эконометрический анализ были направлены на:

1) построение регрессионных моделей (условно названы «зарплатной» и «численной» регрессий), описывающих поведение предприятий на рынке труда;

2) проведение кластерного анализа, позволяющего выявить эмпирические профили поведения группы промышленных предприятий Свердловской области в зависимости от степени активности профсоюзов в переговорном процессе по вопросам занятости и оплаты труда в посткризисный период. 
Исследование включало панельные данные по промышленным предприятиям строительной индустрии Свердловской области. Методология, используемая в данном исследовании, основывалась на эконометрической оценке стандартного регрессионного уравнения:

$$
\ln \left(\text { Wage }_{i}\right)=\alpha+\beta \cdot x_{i}+\gamma \cdot i n_{i}+\varepsilon,
$$

где Wage $_{i}$ - среднемесячная заработная плата работников в $i$-й организации, $x_{i}-$ набор контрольных переменных, характеризующих конкретную организацию для $i$-го наблюдения; $i n_{i}$ - характеристики степени юнионизации работников в $i$-й организации; $\alpha$ - константа; $\beta, \gamma$ - оцениваемые параметры; $\varepsilon$ - ошибка, включающая в себе ненаблюдаемые факторы.

Для проведения регрессионного анализа были введены следующие переменные, приведенные в табл. 1.

Таблица 1

Переменные эконометрической модели оценки факторов, влияющих на политику предприятий в области оплаты труда и занятости работников

\begin{tabular}{|c|c|c|c|}
\hline Переменная & Содержание & $\begin{array}{c}\text { Описание и способ } \\
\text { определения }\end{array}$ & $\begin{array}{c}\text { Источник } \\
\text { информации }\end{array}$ \\
\hline Wage_TU_IPC & $\begin{array}{l}\text { Среднемесячная за- } \\
\text { работная плата в ор- } \\
\text { ганизации в расчете } \\
\text { на } 1 \text { сотрудника, } \\
\text { тыс. руб. }\end{array}$ & $\begin{array}{l}\text { Сведения получе- } \\
\text { ны из профсоюза } \\
\text { работников строи- } \\
\text { тельной индустрии } \\
\text { и промышленности } \\
\text { стройматериалов }\end{array}$ & $\begin{array}{l}\text { Профсоюзная } \\
\text { организация }\end{array}$ \\
\hline Ln_Wage_TU & $\begin{array}{l}\text { Логарифм средне- } \\
\text { месячной заработ- } \\
\text { ной платы в органи- } \\
\text { зации в расчете на } \\
1 \text { работника }\end{array}$ & & \\
\hline Number_TU & $\begin{array}{l}\text { Среднесписочная } \\
\text { численность персо- } \\
\text { нала, чел. }\end{array}$ & $\begin{array}{l}\text { Сведения получе- } \\
\text { ны из профсоюза } \\
\text { работников строи- } \\
\text { тельной индустрии } \\
\text { и промышленности } \\
\text { стройматериалов }\end{array}$ & $\begin{array}{l}\text { Профсоюзная } \\
\text { организация }\end{array}$ \\
\hline
\end{tabular}


Продолжение табл. 1

\begin{tabular}{|c|c|c|c|}
\hline Переменная & Содержание & $\begin{array}{c}\text { Описание и способ } \\
\text { определения }\end{array}$ & $\begin{array}{c}\text { Источник } \\
\text { информации }\end{array}$ \\
\hline Ln_Number_TU & $\begin{array}{l}\text { Логарифм средне- } \\
\text { списочной числен- } \\
\text { ности персонала }\end{array}$ & & \\
\hline$O S P$ & $\begin{array}{l}\text { Общестроительные } \\
\text { предприятия }\end{array}$ & $\begin{array}{l}\text { Если предприятие } \\
\text { относится к данной } \\
\text { группе по виду } \\
\text { деятельности, то } \\
\text { в соответствующей } \\
\text { колонке получает } \\
\text { значение } 1\end{array}$ & \\
\hline$S S M R$ & $\begin{array}{l}\text { Предприятия специ- } \\
\text { ального строитель- } \\
\text { ства и монтажных } \\
\text { работ }\end{array}$ & $\begin{array}{l}\text { Если предприятие } \\
\text { относится к данной } \\
\text { группе по виду } \\
\text { деятельности, то } \\
\text { в соответствующей } \\
\text { колонке получает } \\
\text { значение } 1\end{array}$ & \\
\hline PSI & $\begin{array}{l}\text { Предприятия и ор- } \\
\text { ганизации промыш- } \\
\text { ленности строитель- } \\
\text { ных материалов }\end{array}$ & $\begin{array}{l}\text { Если предприятие } \\
\text { относится к данной } \\
\text { группе по виду } \\
\text { деятельности, то } \\
\text { в соответствующей } \\
\text { колонке получает } \\
\text { значение } 1\end{array}$ & \\
\hline PSI & $\begin{array}{l}\text { Проектные инсти- } \\
\text { туты }\end{array}$ & $\begin{array}{l}\text { Если предприятие } \\
\text { относится к данной } \\
\text { группе по виду } \\
\text { деятельности, то } \\
\text { в соответствующей } \\
\text { колонке получает } \\
\text { значение } 1\end{array}$ & \\
\hline Type_City & $\begin{array}{l}\text { Тип населенного } \\
\text { пункта по удален- } \\
\text { ности от Екатерин- } \\
\text { бурга }\end{array}$ & $\begin{array}{c}0 \text { - Екатеринбург; } \\
1 \text { - спутник Екате- } \\
\text { ринбурга; } \\
2 \text { - удаленность от } \\
\text { Екатеринбурга } \\
\text { более } 100 \text { км }\end{array}$ & \\
\hline
\end{tabular}


Продолжение табл. 1

\begin{tabular}{|c|c|c|c|}
\hline Переменная & Содержание & $\begin{array}{c}\text { Описание и способ } \\
\text { определения }\end{array}$ & $\begin{array}{c}\text { Источник } \\
\text { информации }\end{array}$ \\
\hline Year & $\begin{array}{l}\text { Год на момент на- } \\
\text { блюдения показа- } \\
\text { телей }\end{array}$ & $\begin{array}{l}2008-0, \\
2009,2010-1\end{array}$ & \\
\hline Gain_IPC & $\begin{array}{l}\text { Выручка от ре- } \\
\text { ализации за год, } \\
\text { тыс. руб./год }\end{array}$ & & www.Fira.ru \\
\hline Ln_Gain & $\begin{array}{l}\text { Логарифм выручки } \\
\text { от реализации }\end{array}$ & & \\
\hline Tarif_IPC & $\begin{array}{l}\text { Минимальная та- } \\
\text { рифная ставка, уста- } \\
\text { новленная на пред- } \\
\text { приятии, тыс. руб. }\end{array}$ & $\begin{array}{l}\text { Сведения получе- } \\
\text { ны из профсоюза } \\
\text { работников строи- } \\
\text { тельной индустрии } \\
\text { и промышленности } \\
\text { стройматериалов }\end{array}$ & $\begin{array}{l}\text { Профсоюзная } \\
\text { организация }\end{array}$ \\
\hline TarifOtrasSogl_IPS & $\begin{array}{l}\text { Минимальная } \\
\text { тарифная ставка, } \\
\text { установленная } \\
\text { отраслевым тариф- } \\
\text { ным соглашением, } \\
\text { тыс. руб. }\end{array}$ & $\begin{array}{l}\text { Сведения получе- } \\
\text { ны из профсоюза } \\
\text { работников строи- } \\
\text { тельной индустрии } \\
\text { и промышленности } \\
\text { стройматериалов }\end{array}$ & $\begin{array}{l}\text { Профсоюзная } \\
\text { организация }\end{array}$ \\
\hline DilyaTarTOS & $\begin{array}{l}\text { Отношение мини- } \\
\text { нального тарифа } \\
\text { в организации к ми- } \\
\text { нимальному тарифу, } \\
\text { установленному } \\
\text { отраслевым согла- } \\
\text { шением }\end{array}$ & $\begin{array}{l}\text { Сведения получе- } \\
\text { ны из профсоюза } \\
\text { работников строи- } \\
\text { тельной индустрии } \\
\text { и промышленности } \\
\text { стройматериалов }\end{array}$ & $\begin{array}{l}\text { Профсоюзная } \\
\text { организация }\end{array}$ \\
\hline DolyaOT_TU & $\begin{array}{l}\text { Доля средств на } \\
\text { оплату труда в се- } \\
\text { бестоимости про- } \\
\text { дукции }\end{array}$ & $\begin{array}{l}\text { Сведения получе- } \\
\text { ны из профсоюза } \\
\text { работников строи- } \\
\text { тельной индустрии } \\
\text { и промышленности } \\
\text { стройматериалов }\end{array}$ & $\begin{array}{l}\text { Профсоюзная } \\
\text { организация }\end{array}$ \\
\hline Assets_IPC & $\begin{array}{l}\text { Величина акти- } \\
\text { вов организации, } \\
\text { тыс. руб. }\end{array}$ & & www.Fira.ru \\
\hline
\end{tabular}


Окончание табл. 1

\begin{tabular}{|c|c|c|c|}
\hline Переменная & Содержание & $\begin{array}{c}\text { Описание и способ } \\
\text { определения }\end{array}$ & $\begin{array}{c}\text { Источник } \\
\text { информации }\end{array}$ \\
\hline Ln_Assets & $\begin{array}{l}\text { Логарифм величины } \\
\text { активов организа- } \\
\text { ции }\end{array}$ & & \\
\hline Density & $\begin{array}{l}\text { Доля членов проф- } \\
\text { союза в общей } \\
\text { численности орга- } \\
\text { низации }\end{array}$ & $\begin{array}{l}\text { Сведения получе- } \\
\text { ны из профсоюза } \\
\text { работников строи- } \\
\text { тельной индустрии } \\
\text { и промышленности } \\
\text { стройматериалов }\end{array}$ & $\begin{array}{l}\text { Профсоюзная } \\
\text { организация }\end{array}$ \\
\hline DensityFikt & $\begin{array}{l}\text { Фиктивная перемен- } \\
\text { ная охвата членст- } \\
\text { вом в профсоюзе }\end{array}$ & $\begin{array}{l}1 \text { - если доля чле- } \\
\text { нов профсоюза бо- } \\
\text { лее } 50 \% \text {, иначе - } 0\end{array}$ & $\begin{array}{l}\text { Профсоюзная } \\
\text { организация }\end{array}$ \\
\hline KlassKred & $\begin{array}{l}\text { Класс кредитоспо- } \\
\text { собности }\end{array}$ & $\begin{array}{l}\text { Показатель рас- } \\
\text { считывается базой } \\
\text { данных }\end{array}$ & www.Fira.ru \\
\hline Konvert & $\begin{array}{l}\text { Наличие «серых» } \\
\text { схем при выплате } \\
\text { заработной платы }\end{array}$ & $\begin{array}{c}1 \text { - есть заработная } \\
\text { плата «в кон- } \\
\text { верте»; } \\
0 \text { - нет или отсут- } \\
\text { ствуют сведе- } \\
\text { ния об этом }\end{array}$ & $\begin{array}{l}\text { Профсоюзная } \\
\text { организация }\end{array}$ \\
\hline Expert & $\begin{array}{l}\text { Сильный профсоюз- } \\
\text { ный лидер, (экспер- } \\
\text { тная оценка) }\end{array}$ & $\begin{array}{l}0 \text { - слабый; } \\
1 \text { - умеренно; } \\
2 \text { - сильный }\end{array}$ & $\begin{array}{l}\text { Профсоюзная } \\
\text { организация }\end{array}$ \\
\hline
\end{tabular}

Для анализа поведения предприятий в зависимости от степени активности профсоюзов в переговорном процессе нами был сконструирован показатель, отражающий различные аспекты коллективной солидарности работников, включая такие, как:

а) оценка доли членов профсоюза в общей численности работников организации, продиктованная предположением о том, что чем выше охват профсоюзным членством, тем большее влияние оказывает профсоюз на уровень средней заработной платы его членов;

б) фиктивная переменная охвата членством в профсоюзе, введение которой обусловлено существованием различных способов представительства интересов работников в зависимости от того, более или менее 50 \% коллектива являются членами профсоюза; 
в) доля минимального тарифа, установленного коллективным договором, от размера тарифа отраслевого соглашения, что характеризует размер средней заработной платы на предприятии;

г) экспертная оценка личных качеств (харизматичности) профсоюзного лидера.

Результаты регрессионного анализа представлены в табл. 2.

Среди факторов, влияющих на поведение промышленных предприятий в зависимости от степени активности профсоюзов в переговорном процессе по вопросам занятости и оплаты труда в посткризисный период, наиболее существенными являются следующие:

а) принадлежность к определенному виду деятельности в рамках строительной индустрии: на предприятиях специального строительства и монтажных работ, а также в проектных институтах средняя заработная плата выше, чем на общестроительных предприятиях и предприятиях промышленности стройматериалов, так как профессионально-квалификационный состав работников данных предприятий характеризуется более высоким уровнем подготовки, сложностью выполняемой работы;

б) удаленность от мегаполиса: чем дальше предприятие расположено от Екатеринбурга, тем размер средней заработной платы существенно снижается, что, по нашему мнению, объясняется наличием локальных рынков труда и стоимостью рабочей силы в целом;

в) величина активов компании: чем крупнее компания по величине активов, тем средняя заработная плата работников выше, поскольку более крупные компании способны обеспечить выполнение более крупных заказов, имеют иное техническое оснащение, что обусловливает более высокую производительность труда работников и ряд иных обстоятельств;

г) финансовые результаты деятельности компании: в организациях, кредитный рейтинг которых имеет худшие значения, средняя заработная плата ниже;

д) на предприятиях, использующих «серые» схемы при выплате заработной платы, официальная часть средней заработной 


\begin{tabular}{|c|c|c|c|c|c|c|c|c|c|}
\hline \multirow{9}{*}{ 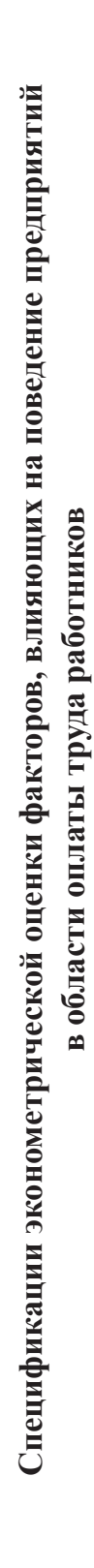 } & \multirow{4}{*}{\multicolumn{2}{|c|}{ 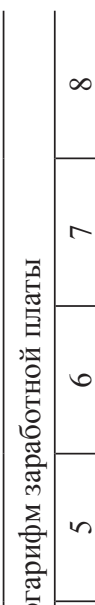 }} & \begin{tabular}{c}
$*$ \\
$*$ \\
$*$ \\
$\infty$ \\
$\infty$ \\
$\stackrel{\infty}{*}$ \\
\hdashline
\end{tabular} & 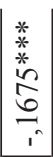 & $\begin{array}{l}\stackrel{*}{*} \\
\stackrel{*}{*} \\
\stackrel{2}{\infty} \\
\stackrel{\infty}{0}\end{array}$ & \begin{tabular}{l}
$*$ \\
$*$ \\
$*$ \\
\multirow{\sigma}{*}{} \\
-
\end{tabular} & 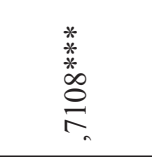 & 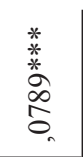 & 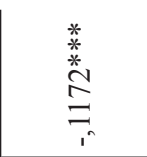 \\
\hline & & & $\begin{array}{c}* \\
* \\
* \\
\infty \\
\infty \\
\infty \\
\end{array}$ & 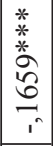 & 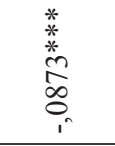 & $\begin{array}{l}* \\
\stackrel{*}{*} \\
\stackrel{*}{*} \\
\stackrel{\infty}{-}\end{array}$ & 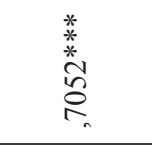 & 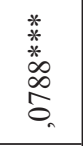 & 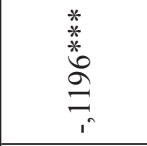 \\
\hline & & & 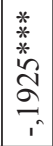 & 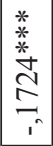 & $\begin{array}{l}* \\
\stackrel{*}{*} \\
\stackrel{*}{\sigma} \\
\stackrel{\sigma}{\sigma}\end{array}$ & $\begin{array}{l}* \\
* \\
* \\
* \\
+ \\
\infty \\
+\end{array}$ & $\begin{array}{l}* \\
* \\
* \\
0 \\
0 \\
0\end{array}$ & $\begin{array}{l}\stackrel{*}{*} \\
\stackrel{*}{*} \\
\stackrel{+}{+} \\
0\end{array}$ & 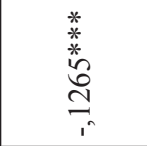 \\
\hline & & & 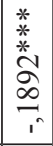 & \begin{tabular}{c}
$*$ \\
$*$ \\
$*$ \\
6 \\
6 \\
0 \\
\hdashline \\
\end{tabular} & \begin{tabular}{l}
$*$ \\
$*$ \\
$*$ \\
\multirow{*}{*}{} \\
$\infty$ \\
0 \\
0 \\
1
\end{tabular} & 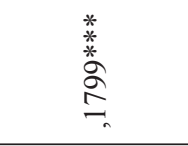 & $\begin{array}{l}* \\
* \\
\stackrel{*}{*} \\
\stackrel{+}{\leftarrow}\end{array}$ & 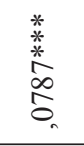 & \begin{tabular}{l}
$*$ \\
$*$ \\
$*$ \\
\multirow{*}{*}{} \\
$\stackrel{*}{\Xi}$
\end{tabular} \\
\hline & 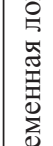 & $\nabla$ & 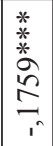 & 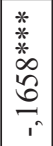 & 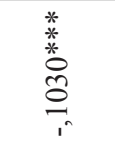 & 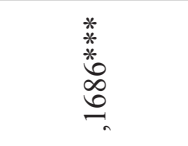 & \begin{tabular}{l}
$*$ \\
$*$ \\
$*$ \\
$\infty$ \\
\multirow{\sigma}{*}{}
\end{tabular} & $\begin{array}{l}\stackrel{*}{*} \\
\stackrel{*}{*} \\
\stackrel{\infty}{ \pm} \\
0\end{array}$ & 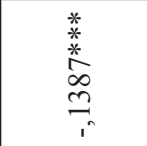 \\
\hline & 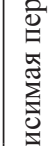 & $m$ & \begin{tabular}{l}
$*$ \\
$*$ \\
\multirow{2}{*}{} \\
$\stackrel{*}{2}$ \\
$\underset{1}{*}$
\end{tabular} & $\begin{array}{c}* \\
* \\
* \\
\sigma \\
\sigma \\
-1 \\
i^{\circ} \\
\end{array}$ & $\begin{array}{l}* \\
* \\
* \\
0 \\
0 \\
0 \\
i \\
1\end{array}$ & \begin{tabular}{l}
$*$ \\
$*$ \\
\multirow{2}{*}{} \\
$\stackrel{*}{\Sigma}$ \\
-
\end{tabular} & $\begin{array}{l}\stackrel{*}{*} \\
\stackrel{*}{ \pm} \\
\stackrel{*}{\odot}\end{array}$ & $\begin{array}{l}* \\
* \\
* \\
* \\
n \\
\infty \\
0\end{array}$ & 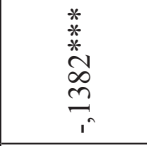 \\
\hline & लి & $\sim$ & $\begin{array}{l}* \\
* \\
* \\
\stackrel{*}{\Omega} \\
\underset{1}{*}\end{array}$ & 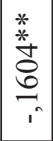 & 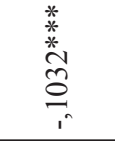 & 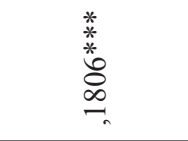 & \begin{tabular}{l}
$\frac{*}{*}$ \\
$*$ \\
\multirow{*}{*}{} \\
$\stackrel{0}{\infty}$ \\
$\stackrel{\infty}{\circ}$
\end{tabular} & $\begin{array}{l}* \\
\stackrel{*}{*} \\
\stackrel{*}{*} \\
\stackrel{0}{0}\end{array}$ & \\
\hline & & - & 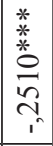 & 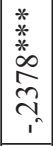 & $\begin{array}{l}* \\
* \\
* \\
* \\
n \\
\infty \\
0 \\
0\end{array}$ & 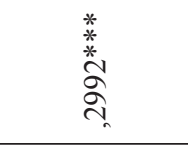 & 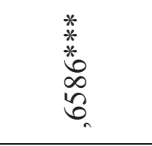 & & \\
\hline & & & 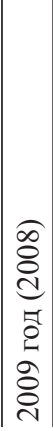 & 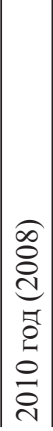 & 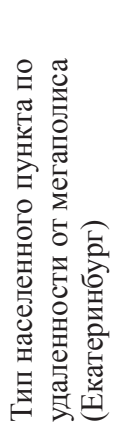 & 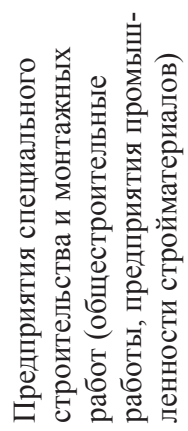 & 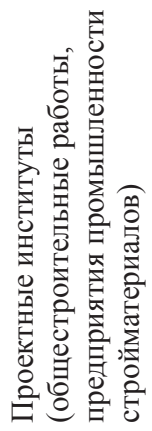 & 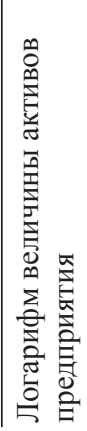 & 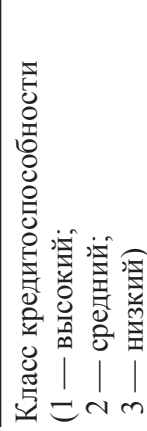 \\
\hline
\end{tabular}




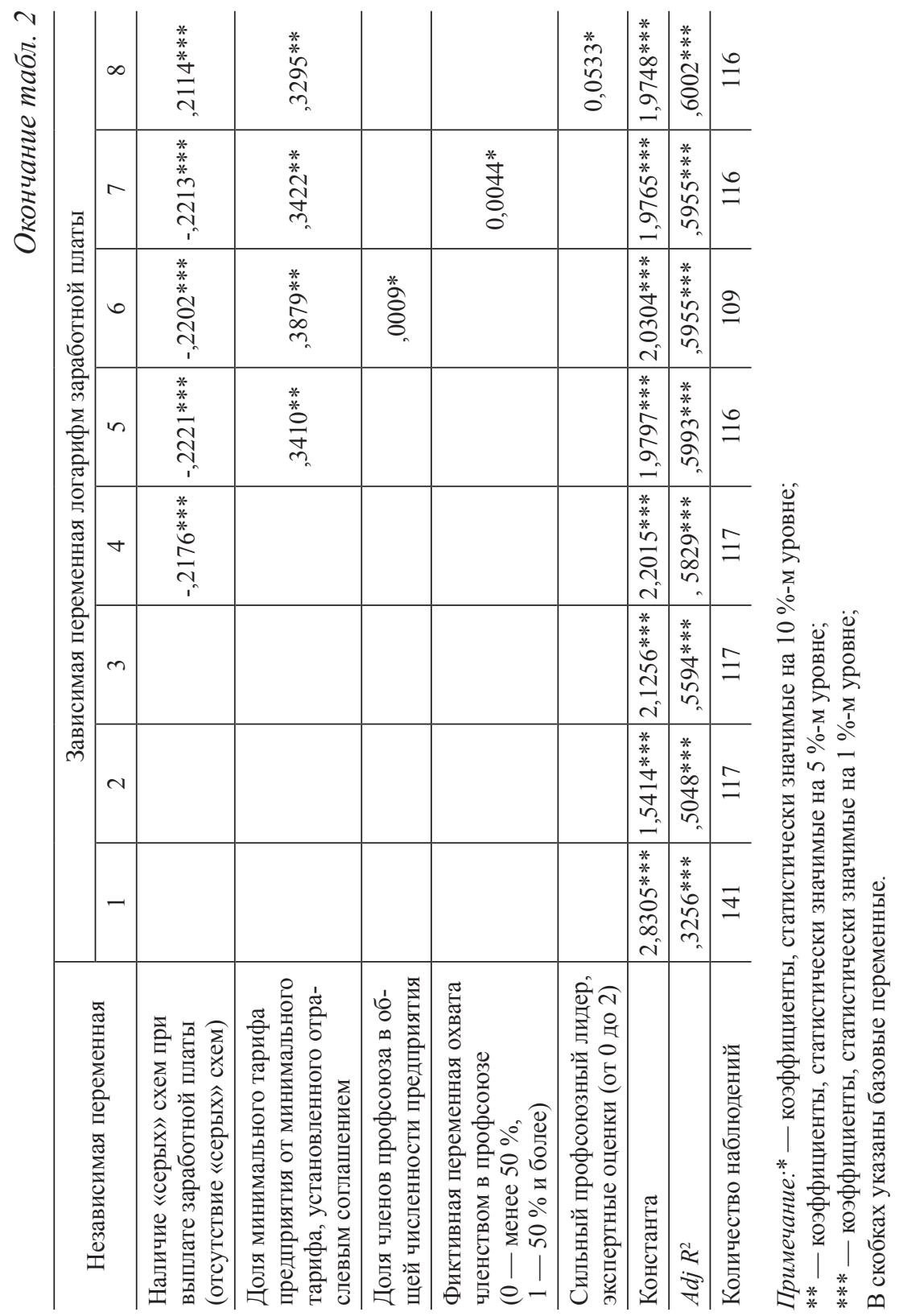


платы ниже, чем в организациях, не практикующих выплаты заработной платы «в конвертах»;

е) в качестве фактора, отражающего влияние на среднюю заработную плату степени юнионизации, статистически значим показатель доли минимального тарифа к тарифу, установленному отраслевым соглашением. Обращает на себя внимание тот факт, что от доли охвата членством в профсоюзе и от лидерских качеств руководителя первичной профсоюзной организации средняя заработная плата меняется не существенно, что свидетельствует о слабом влиянии профсоюзов на политику зарплатообразования и занятости работников.

Нами была предпринята попытка выявить зависимость между степенью юнионизации работников и их численностью, но пока не удалось найти значимых переменных: единственный показатель, наиболее сопряженный с численностью, - величина активов предприятия, рассматривается нами как эндогенный. Кроме того, отрасль строительной индустрии отличается ярко выраженной сезонностью, что, по нашему мнению, приводит к смещенным оценкам в результатах; наблюдается тенденция «сбрасывания» организациями непрофильных активов и вывода некоторых видов деятельности на аутсорсинг. Не располагая достаточными данными о причинах изменения численности, сложно оценить детерминанты.

Для определения эмпирических профилей поведения предприятий в зависимости от степени активности профсоюзов в переговорном процессе по вопросам занятости и оплаты труда в посткризисный период, нами был проведен кластерный анализ в рамках которого допускалось, что каждое предприятие дифференцирует способы регулирования численности работников и размеры среднемесячной заработной платы, изменяя их в одном направлении, либо увеличивая или снижая их одновременно, либо сохраняя численность работников, изменяя только заработную плату, либо изменяя их в разных направлениях, сокращая численность при повышении заработной платы и наоборот. Таким образом, в качестве переменных, определяющих разделение на кластеры, были использованы показатели изменения среднемесячной заработной 
платы и численности работников к предшествующему периоду в процентном выражении. Расчеты показали, что можно выделить четыре кластера:

- в первый кластер попали предприятия с низкой степенью активности профсоюзов в переговорном процессе с численностью работников от 200 до 1000, на которых с 2007 по 2010 гг. численность и заработная плата снижалась, и лишь в 2011 г. произошел их рост;

- во второй кластер вошло лишь одно предприятие, продемонстрировавшее на протяжении всего анализируемого периода рост заработной платы и численности персонала. Профсоюзной организации на предприятии нет, численность работников - более 600 человек;

- третий кластер составили предприятия, на которых за период 2007-2010 гг. происходило снижение заработной платы, в 2011 г. снижение прекратилось, численность работников показывала рост за весь период анализа, около 40 \% этих предприятий имеют профсоюз, а численность работников составляет от 100 до 500 чел.;

- наиболее представительным является четвертый кластер, основную массу (более 90 \%) которого составляют предприятия с высокой степенью активности профсоюзов в переговорном процессе.

Таким образом, установленные нами модели поведения предприятий с разной степенью активности профсоюзов в переговорном процессе по вопросам занятости и оплаты труда отражают различные реакции работодателей и работников на изменение институциональной среды, регионального и локального рынков труда. Предприятия с более высоким уровнем оплаты труда и меньшей степенью юнионизации работников (при прочих равных условиях) демонстрируют большую гибкость (эластичность занятости по объему выпуска и по заработной плате по сравнению с эластичностью заработной платы по производительности труда). Полученные результаты проведенного исследования, по нашему мнению, позволяют разработать рекомендации для проведения 
государственной политики, способствующей повышению эффективности трудового посредничества и уменьшения трансакционных издержек на рынке труда.

\section{Список литературы}

1. Flanders A. The tradition of voluntarism / A. Flanders. British Journal of Industrial Relations. 1974. № 12 (3). P. 352-370.

2. Edwards P. Great Britain: Still Muddling Through / P. Edwards, M. Hall, R. Hyman, P. Marginson, K. Sisson, J. Waddington, D. Winchester ; eds.: A. Ferner, R. Hyman : Industrial Relations in the New Europe. Oxford, Blackwell. 1992. P. 1-68.

3. Zagelmeyer $S$. The Development of Governance Structures in Britain and Germany: A Comparative Inquiry / S. Zagelmeyer // Industrielle Beziehungen. 2004. № 11. 1+2. P. 61-77.

4. Streeck W. German Capitalism: Does it Exist? Can it Survive? / W. Streeck Political economy of modern capitalism: mapping convergence and diversity ; ed. by Colin Crouch and Wolfgang Streek. London: Sage, 1997. P. 33-54.

5. Jacobi $O$. Renewal of the collective bargaining system? / O. Jacobi. The changing contours of German industrial relations ; ed. W. Mueller-Jentsch, H. Weitbrecht. Reiner Hampp Verlag Muenchen und Mering, 2003. P. 15-39.

6. Рощин C. Экономика труда: экономическая теория труда / С. Рощин, Т. Разумова. М. : ИНФРА-М, 2000. С. 289-306.

7. Эренберг Р. Дж. Современная экономика труда. Теория и государственная политика / Р. Дж. Эренберг, Р. С. Смит. М. : Изд-во МГУ, 1996. C. $499-520$.

8. Hicks J. R. The Theory of Wages / J. R. Hicks. 2d ed. New York : St. Martin's Press, 1966.

9. Уильямсон О.И. Экономические институты капитализма / О. И. Уильямсон. СПб. : Лениздат ; CEV Press, 1996. С. 384-420.

10. Olson M. The logic of collective action / M. Olson. Cambridge, MA, Harvard University Press, 1965. 275 p.

11. Олимпиева И. Б. Российские профсоюзы в системе регулирования социально-трудовых отношений: особенности, проблемы и перспективы исследования М. : МОНФ; Центр независимых социологических исследований, 2010. 150 с.

12. Козина И. М. Корпорации, трудовые отношения и профсоюзы вариант России / И. М. Козина // Мир России: Социология, этнология. 2009. T. XVIII. № 1. С. 144-163. 


\section{$\S 4$. Стратегическое партнерство государства и бизнеса в России и зарубежом}

В современных научных исследованиях, как правило, авторы стремятся объяснить изменения, происходящие в жизненно важных сферах. Экономика, несомненно, такая сфера. В ней в последние десятилетия происходят качественно новые процессы. К таковым можно отнести взаимодействие государства, общества и бизнеса - высший тип партнерства. За рубежом он получил название Public-Private Partnership (PРP). В России принят термин «государственно-частное партнерство» (ГЧП).

Действительно, союз государства и бизнеса - явление чрезвычайно перспективное. Он мог возникнуть только в определенных условиях: когда государству для решения определенных задач потребовался союзник и когда бизнес созрел для понимания, что дальнейшее развитие экономики и общества сопряжено с большими затруднениями. В этой ситуации необходима надежная опора, которой может стать государство.

Союз государства и бизнеса имеет ряд преимуществ перед индивидуальным бизнесом. Многие уже отмечены исследователями. К ним относятся большие возможности решать стратегические задачи.

ГЧП — сложная организационная конструкция. Она выходит за рамки экономики, оказывает влияние на другие сферы жизни общества - политику, науку, культуру и др.

Именно как сложное явление характеризует партнерство государства и бизнеса В. Г. Варнавский. В современном понимании хозяйственное партнерство государства и частного сектора - это «институциональный и организационный альянс между государством и частным бизнесом в целях реализации масштабных, национальных и международных, общественно значимых проектов 
в широком спектре сфер деятельности - от развития стратегически важных отраслей промышленности и НИОКР до обеспечения общественных услуг» [1]. Здесь обозначена цель и намечены пути ее реализации.

Соглашаясь с этим определением, мы полагаем, что автор не отметил влияние союза на жизненно важные сферы, указанные выше.

Отмечая положительное влияние создаваемого альянса, нельзя упускать и возможные затруднения на этом пути. Для исследования необходим специальный анализ.

Мы сгруппировали их следующим образом:

- организационные (разработка механизмов взаимодействия);

- экономические, в том числе финансовые (инвестирование, распределение доходов).

Серьезную отдачу от ГЧП можно ожидать, когда партнеры тщательно продумают все возможные плюсы и минусы союза.

Альянс государства и бизнеса уже действует в таких развитых странах, как Англия (тэтчеризм), США (рейганомика), Япония. С определенной спецификой работает в Турции, некоторых странах Латинской Америки.

Идеи о взаимодействии государства и бизнеса стали именовать «неокорпоративизмом». Они присутствуют в моделях капитализма. В настоящее время наиболее распространены американская модель, европейская модель и модель ГЧП стран третьего мира.

Для американской модели характерно сочетание неолиберальных (неоклассических) идей с неокорпоративизмом. В соответствии с концепцией неолибералов в модель заложены следующие принципы:

- свобода рынка;

- минимизация роли государства;

- ограниченная перераспределительная политика;

- низкие социальные издержки бизнеса;

- взаимная автономия государства и бизнеса;

- ограничение влияния бизнеса на процессы выработки политико-административных решений. 
И вместе с тем ряд принципов государство допускает в экономику ограниченно. Это:

- конкурентный подход к взаимодействию государства и бизнеса;

- свобода самореализации бизнеса в ГЧП;

- солидарная ответственность партнеров за социально-экономическое развитие общества.

Европейскую модель отличает консенсусный подход в отношениях государства и бизнеса. Теоретической базой этой модели является плюрализм Ф. Шмиттера и Г. Лембуха. Соответственно предусматриваются активные действия обоих партнеров. Но направляющая роль во взаимоотношениях отводится государству. Ответственность за социально-экономическое развитие ложится на обоих партнеров, но в большей степени на государство. Свои особенности реализации этой модели существуют в Скандинавии, Германии (германский корпоративизм) [2].

Страны третьего мира представляют свою модель взаимоотношений бизнеса и государства:

- ограничение капитализма и нацеленность на извлечение ренты в странах третьего мира;

- сращивание политической и экономической власти как основа для извлечения ренты;

- взаимное усиление политической и экономической власти;

- захват бизнеса (business capture), захват государства (state capture) и системы обменов;

- феномен капитализма для своих (crony capitalism);

- олигархический и бюрократический капитализм;

- коррупция как элемент взаимодействия государства и бизнеса в странах третьего мира;

- авторитарный корпоративизм как принцип взаимодействия государства и бизнеса;

- корпоративизм как механизм контроля государства над бизнесом. 
Ни одна модель не может быть представлена в чистом виде.

Особый интерес вызывает турецкая модель ГЧП. Она отличается многообразием форм взаимодействия.

После создания республики Турция в 1923 г. выбрала свой путь модернизации, как оказалось, оптимальный для мусульманской страны, сочетающий в себе преимущества американской и европейской моделей ГЧП.

Из многообразия форм государственно-частного партнерства, характерных для Турции, можно вычленить следующие:

- контрактные отношения;

- арендные отношения;

- аффермажные соглашения (заключается для эксплуатации объектов, при этом правовую ответственность за предоставление услуг несет не государство, а частная фирма, которая получает и отвечает за все риски, связанные с эксплуатацией);

- финансовая аренда (лизинг);

- государственно-частные предприятия;

- соглашение о разделе продукции (обычно соглашение о разделе продукции является договором, заключенным между зарубежной добывающей компанией и государственным предприятием (государственной стороной), уполномочивающей подрядчика провести поисково-разведочные работы и эксплуатацию в пределах определенной области в соответствии с условиями соглашения) [3];

- концессионные соглашения.

- финансово-промышленные группы;

- сорегулирование бизнеса и власти (долгосрочные публичные договоры о сотрудничестве; участие в целевых комплексных программах; выполнение заказов для государственных и муниципальных нужд; совместные государственно-частные проекты; государственная поддержка малого и среднего бизнеса; дерегулирование, т. е. передача отдельных функций государственных органов саморегулируемым и иным негосударственным организациям); 
- аутсорсинг (передача субъектам предпринимательской деятельности прав на оказание различного рода публичных услуг: государственных, социальных, негосударственных социальных и др.);

- совместное правотворчество, т. е. активное участие представителей бизнеса в правотворчестве субъектов права законодательной инициативы (проведение экспертизы по заказу соответствующего государственного органа независимыми саморегулируемыми организациями, центрами, институтами и т. п. проектов федеральных законов, нормативных актов Правительства Российской Федерации, органов государственной власти субъектов Федерации и муниципальных нормативных актов);

- информационное взаимодействие власти и бизнеса (консультации, семинары, круглые столы и т. п.)

Пять основных шагов, обусловившие рост экономики Турции: 1. Снижены налоги:

- применение сниженных ставок по налогу на прибыль предприятий в Турции на доходы, полученные от инвестиций в специальных отраслях и отдельных регионах;

- отмена подоходного налога с заработной платы;

- поддержка в части страховых премий работодателей по социальному страхованию;

- освобождение от предварительного налога для отдельных физических и юридических лиц, действующих в особых зонах - зонах технологического развития;

- освобождение от предварительного налога для персонала, задействованного в НИОКР, на территории зон технологического развития;

- отмена НДС для этих предприятий.

2. Ликвидированы таможенные барьеры для импорта технологий и оборудования. До 100 \% освобождение от таможенных пошлин обычно предоставляется, если инвестиции обеспечены сертификатом стимулирования инвестиций. 
Импорт машин и оборудования и сырья, полуфабрикатов и расходных материалов может освобождаться от таможенных пошлин и сборов с капитала, также как и импорт использованного оборудования, бывших в употреблении машин и оборудования на определенных условиях.

Созданы тепличные условия для притока иностранного капитала.

В Турции и в других государствах, ориентированных на устойчивое развитие туризма, принимались меры по привлечению иностранных и местных инвесторов. Среди наиболее популярных выгодные условия аренды земельных участков, упрощенные процедуры вхождения инвесторов в особой экономической зоне (ОЭ3), административная поддержка, налоговые льготы, долгосрочные кредиты под низкую процентную ставку, компенсация расходов при ввозе оборудования из-за рубежа, возможность найма иностранного персонала и пр.

Для привлечения капиталов новая власть уравняла в правах отечественных и зарубежных инвесторов, уменьшив количество необходимых разрешительных процедур для последних.

С целью привлечения зарубежного капитала пришлось внести изменения в фискальную политику. Импорт технологий и поточных линий в Турции был освобожден от НДС и таможенной пошлины. В итоге по темпам роста экспорта электроники Турция теперь стоит на втором месте в мире после Китая. К примеру, турецкая компания Vestel Group контролирует более 20 \% европейского рынка телевизоров.

Еще большим стимулом для инвесторов стало снижение в 2006 г. основной ставки налога на прибыль с 30 до 20 \%. Это на 2,5 \% меньше среднеевропейского показателя и на 4 \% - азиатского. Как результат, крупный капитал хлынул в страну. Если в 2003 г. объем прямых иностранных инвестиций составлял 1,7 млрд долл., то в 2007-м он перевалил за 22 млрд долл. Число иностранных компаний за аналогичный период увеличилось втрое, достигнув 18 тыс. [4]. 
Система налогообложения как для иностранцев, так и для резидентов, ведущих свой бизнес в Турции, при наличии зарегистрированной в Турции компании, ничем не отличается. Согласно закону о прямых иностранных инвестициях в Турцию компании, образованные на территории Турции с участием иностранного капитала имеют те же права и обязанности, которыми обладают компании, образованные только с участием турецкого капитала. Если же говорить о подоходном налоге, то для иностранцев даже предусмотрены льготы по его уплате.

В зависимости от размера капиталовложений и количества рабочих мест, инвестор получает льготы. Государство на несколько лет частично или полностью освобождает его от налогов, продает электричество и воду со скидкой 20-50 \%, платит взносы в фонд соцстрахования. Похожие льготы также получают инвесторы, которые работают в экономически отсталых регионах или вкладывают средства в экспортноориентированные отрасли.

Основная часть инвестиций поступает в Турцию из ЕС и часто сопровождается передачей технологий и ноу-хау. Инвестиции из стран зоны Персидского залива также растут, однако передачи ценного опыта при их осуществлении не происходит. Прямые иностранные инвестиции из ЕС составляли 80 \% совокупного ввоза таких инвестиций в Турцию в 2002 г., 60 \% — в 2005 г. и $79 \%$ в 2009 г; капиталовложения такого типа из стран зоны Персидского залива соответственно 1,2 и 3 \%. Определенная часть иностранных инвестиций, поступающих в Турцию, связана с наличием у Турции Таможенного союза с ЕС и перспективой вступления в ЕС [5].

3. Дотации на НИОКР активно содействуют научно-техническому прогрессу. В соответствии с законом о налоге на прибыль, организации, которые проводят работы по НИОКР, могут рассчитывать на дотации, равные 100 \% затрат на НИОКР.

4. Сформированы промышленные зоны, где производители получают фискальные льготы. Турецкие зоны свободной торговли (3СТ) - это районы, определенные Советом министров в рамках политических границ Турции, но вне таможенных границ, где все виды производства, коммерческой деятельности и конкретных 
виды услуг поощряются посредством определенных налоговых освобождений и мер. В этих зонах предусмотрено:

- освобождение от предварительного налога для управляющей компании;

- освобождение от предварительного налога для отдельных физических и юридических лиц, действующих в этих зонах.

5. Государственная поддержка малого и среднего бизнеса осуществляется через организацию KOSGEB (Управление поддержки и развития малых и средних предприятий), которая предоставляет разнообразные меры стимулирования новых предприятий и предпринимателей. Среди них:

- консалтинг и подготовка кадров предприятий малого и среднего бизнеса в Турции;

- поддержка прав интеллектуальной собственности в промышленности (для получения патентов, удостоверений промышленного образца и пр.);

- поддержка информационных технологий (для компьютерного программного обеспечения, поддержка начала электронного бизнеса) предприятий малого и среднего бизнеса в Турции;

- поддержка развития качества на предприятиях малого и среднего бизнеса в Турции;

- поддержка маркетинговых исследований и продвижение экспорта предприятий малого и среднего бизнеса в Турции;

- поддержка развития международного сотрудничества предприятий малого и среднего бизнеса в Турции.

KOSGEB является проводником государственной политики.

Ставка на малый и средний бизнес, который уже превышает 55 \% в структуре экономики, - это важная черта экономики Турции. В стране создано и работает свыше 3,5 миллиона предприятий малого и среднего бизнеса. И здесь очень велика роль государства, которое имеет механизмы поддержки этого сектора, в том числе стимулируя его экспортную направленность. В частности, при поддержке KOSGEB субсидированы кредиты более чем 
200 тысяч предприятий и предоставлено кредитов на сумму свыше 7 млрд долл. Чтобы получать поддержку KOSGEB, достаточно работать на территории Турции, при этом не имеет значения, кто входит в этот бизнес - резиденты страны или иностранные акционеры. Доступ к поддержке от государства максимально упрощен: все процедуры проходят в режиме on-line [6].

На территории заброшенных городских пустырей созданы профильные промышленные зоны. Например, зона кожевенных предприятий под Стамбулом - около 300 фирм, занимающихся всем - от выделки кожи до пошива одежды и обуви. Созданы объединения производителей ткацкой и пищевой промышленности. Для льготного кредитования этих предприятий был образован Народный банк. По всей стране открыто около 1 тыс. офисов, директора которых имеют право самостоятельно выдавать кредит до 35 тыс. долл. на клиента.

В Южной Анталье в Турции по такой схеме было запущено в эксплуатацию свыше 20 отелей. Государство за свой счет построило автомагистраль от Антальи до курортной зоны и асфальтированные подъезды к туробъектам, создало системы телекоммуникации, энергоснабжения, водоснабжения, водоотведения, мусоропереработки. Как сервисный центр новой туристической зоны обустраивался поселок Кемер: строилось жилье для сотрудников отелей, учебный центр, медицинская клиника. Был построен порт. После того, как государство выполнило свои планы по развитию социальной и инженерной инфраструктуру, к проекту присоединились частные инвесторы, 80 \% из которых составили турецкие компании.

Государство также оказывает серьезную поддержку малому бизнесу в расходах на энергетику.

Бизнес отвечает государству такими же социально ответственными действиями.

За короткий срок Турция из рассыпающегося на куски европейского аутсайдера превратилась в 15-ю экономику мира. Этому способствовала особая государственная политика: тепличные 
условия для инвесторов, протекция для экспортеров и комфортная зона для мелкого бизнеса.

Лондонский еженедельник Economist в специальном докладе, посвященном анализу современной ситуации в Турции, обратил внимание «на необычно высокую активность» в ее национальном хозяйстве и отметил, что «темпы развития страны будут, по всей вероятности, более значительными, чем почти в любой европейской стране». Прирост ВВП в 2011 г. составил 8,2 \%, а в IV квартале того же года - 9,2 \%, т. е. Турция оказалась на 3-м месте в мире после Китая и Сингапура, без учета некоторых небольших стран, не играющих заметной роли в мировом хозяйстве. Некоторые сектора национальной экономики показали еще более высокие результаты. Например, в туристическом секторе подъем 2012 г. достиг 11 \%. Благоприятные тенденции в сфере занятости, в частности в 2012 г. имело место сокращение безработицы с 9,4 до 9,2 \%, способствовали росту располагаемых доходов населения, что обеспечило повышение покупательной способности. Потребление в секторе домохозяйств в 2012 г. выросло на 6,6 \%, его динамика оставалась весьма активной и в 2013 г. При такой конъюнктуре степень использования производственных мощностей была близкой к потенциально возможной [7]. Возможные направления воздействия государства на собственников.

Новое правительство, возглавляемое министром экономики Али Бабаджаном и министром финансов Кемалем Унакитаном оба получили образование в США, - использовало свое большинство в парламенте для проведения этих и других реформ.

Результаты экстренных преобразований появились довольно быстро. Если в 2001 г. ВВП Турции упал на $10 \%$, то уже через три года страна вышла в плюс, достигнув рекордных 8,9\% [8]. В 2001 г. страну поразила гиперинфляция. Чтобы остановить ее лавину, турецкое правительство в срочном порядке подготовило антикризисную программу. Ее суть свелась к четырем тезисам:

- объединение государственных банков и их освобождение от политического влияния;

- масштабная приватизация крупнейших госпредприятий; 
- реструктуризация частных банков и ужесточение условий выдачи ими кредитов;

- повышение тарифов в энергетической сфере.

За последующие десять лет турецкая экономика стала одной из 15 мощнейших экономик в мире и шестой в Европе. Инфляция в 2010 г. снизилась до рекордно низкого за последние 40 лет уровня - 6,4 \%, а ВВП с 2002-го увеличился втрое, достигнув 700 млрд долл. [10].

Нет в Турции привычной для многих бизнесменов бюрократии. Чиновников отстранили от регулирования предпринимательской деятельности. Всем занимается Координационный совет по улучшению инвестиционной среды, учрежденный совместно государственным и частным сектором, и Агентство по продвижению инвестиций, которое с 2007 г. помогает инвесторам регистрировать свои компании в Турции.

Достигнутых высоких результатов в своем экономическом развитии за последние годы Турецкая Республика во многом добилась благодаря грамотному осуществлению государственной политики. Очень взвешенное, продуманное отношение государства к бизнесу, в том числе к малому и среднему, привело к тому, что конкурентоспособность производимой в стране продукции и создание конкурентной среды были основными критериями в сфере экономики. Результатом явилось то место, которое занимает Турция в двадцатке ведущих экономик мира.

Для России государственно-частное партнерство - относительно новая форма средне- и долгосрочного взаимодействия государства и бизнеса для решения общественно значимых задач на взаимовыгодных условиях. Даже в Великобритании, считающейся родоначальницей этой формы реализации инвестиционных проектов, первые шаги по формализации ГЧП были приняты в не столь уж далеком 1981 г. В нашей стране это понятие в узком смысле (если не ограничиваться понятием «концессия») впервые появилось в законодательном акте лишь в 2006 г. в Санкт-Петербурге.

Традиционными сферами государственно-частного партнерства во всех странах являлись объекты социальной и транспортной 
инфраструктуры, а движущей силой процесса была тенденция к сокращению участия государства в экономике. При этом нельзя считать, что любое взаимодействие государства и частного капитала — это ГЧП. Критерием может являться выполнение бизнесом функций, которые традиционно выполняло государство. Развитие и поддержание инфраструктуры (производственной, транспортной, социальной) - наиболее типичный пример.

В мире сейчас нет единого представления о том, в какой законодательной форме должно быть оформлено государственно-частное партнерство. В некоторых развитых странах - признанных лидерах по степени развития ГЧП — единого закона нет, а основные принципы его заложены в различные законодательные акты и нормы гражданского права. Например, во Франции, Англии, Японии, Австралии. В других государствах приняты отдельные законы о ГЧП. Такая ситуация сложилась в Германии, Бразилии, Греции, Египте, Анголе и ряде стран Восточной Европы.

Исследователи проблемы считают, что причиной сложившейся ситуации является процесс развития ГЧП. Там, где он шел естественным образом («снизу»), соответствующие правки постепенно вносились в уже действующие законы. Страны, в которых приняты отдельные законы о ГЧП, входят в группу стран с догоняющей экономикой (исключение из перечисленных - Германия), поэтому развитие государственно-частного партнерства происходило в них «сверху». Другими словами в этой группе стран ГЧП требует от государства активного участия и продвижения. Россия, как и страны СНГ, относится к группировке стран с догоняющей экономикой.

В некоторых странах бывшего СССР приняты законы о ГЧП (на Украине, Молдове, Кыргызстане). В других существуют отдельные акты, регулирующие различные формы ГЧП.

В России также действуют региональные акты и Федеральные законы от 21.07.2005 г. № 115-Ф3 «О концессионных соглашениях» и от 21.07.2005 г. № 94-Ф3 «О размещении заказов на поставки товаров, выполнение работ, оказание услуг для государственных и муниципальных нужд», которые также оговаривают варианты 58 
реализации проектов ГЧП. В какой-то степени регулирует ГЧП и Федеральный закон от 22.07.05 г. № 116-Ф3 «Об особых экономических зонах в РФ» (поскольку предоставление бизнесу льгот на определенной территории - тоже вариант ГЧП в широком смысле). Законодательство о ГЧП принято в 69 субъектах России (табл. 3).

Вместе с тем нельзя не отметить, что большая часть законодательных актов носит декларативный характер.

Таблиия 3

\section{Типология ГЧП в зависимости от объема прав и обязанностей частного партнера}

\begin{tabular}{|c|c|c|}
\hline $\begin{array}{l}\text { Сокра- } \\
\text { щение }\end{array}$ & Расшифровка & Описание \\
\hline BOT & $\begin{array}{l}\text { Build, Operate, Transfer } \\
\text { (Построй — Управляй - } \\
\text { Передай) }\end{array}$ & $\begin{array}{l}\text { Концессионный механизм: } \\
\text { строительство, право пользования (без } \\
\text { права собственности) в течение срока } \\
\text { соглашения и передача государству }\end{array}$ \\
\hline BOOT & $\begin{array}{l}\text { Build, Own, } \\
\text { Operate, Transfer } \\
\text { (Построй - Владей - } \\
\text { Управляй - Передай) } \\
\text { (подразумевается право } \\
\text { собственности, но не } \\
\text { только владения) }\end{array}$ & $\begin{array}{l}\text { Аналогично п. 1, но право собственности } \\
\text { на время действия контракта } \\
\text { принадлежит частному партнеру }\end{array}$ \\
\hline ВТO & $\begin{array}{l}\text { Build, Transfer, Operate } \\
\text { (Построй — Передай - } \\
\text { Управляй) }\end{array}$ & $\begin{array}{l}\text { Аналогично п. 1, только объект } \\
\text { передается государству сразу после } \\
\text { строительства. Частный партнер } \\
\text { обслуживает объект в течение срока } \\
\text { действия соглашения, а публичный } \\
\text { возмещает затраты регулярными } \\
\text { платежами (контракт жизненного цикла) }\end{array}$ \\
\hline $\mathrm{BOO}$ & Build, Own, Operate & $\begin{array}{l}\text { Аналогично п. 2, но по истечении } \\
\text { срока соглашения объект остается } \\
\text { в собственности частного партнера }\end{array}$ \\
\hline BOMT & $\begin{array}{l}\text { Build, Operate, } \\
\text { Maintain, Transfer } \\
\text { (Построй — Управляй - } \\
\text { Поддерживай —- Передай) }\end{array}$ & $\begin{array}{l}\text { Акцент на поддержке жизнеспособности } \\
\text { и обслуживании объекта. Право } \\
\text { собственности остается у публичного } \\
\text { партнера }\end{array}$ \\
\hline
\end{tabular}




\begin{tabular}{c|l|l}
\hline $\begin{array}{c}\text { Сокра- } \\
\text { щение }\end{array}$ & \multicolumn{1}{|c|}{ Расшифровка } & \multicolumn{1}{c}{ Описание } \\
\hline DBOOT & $\begin{array}{l}\text { Design, Build, Own, } \\
\text { Operate, Transfer } \\
\text { (Спроектируй — } \\
\text { Построй — Владей — } \\
\text { Управляй — Передай) }\end{array}$ & $\begin{array}{l}\text { Аналогично п. 2, но в обязанности } \\
\text { частного партнера входит } \\
\text { и проектирование объекта соглашения }\end{array}$ \\
\hline DBFO & $\begin{array}{l}\text { Design, Build, Finance, } \\
\text { Operate (Спроектируй — } \\
\text { Построй — Владей - } \\
\text { Управляй — Передай) }\end{array}$ & $\begin{array}{l}\text { Акцент на обязанности частного } \\
\text { партнера финансировать строительство } \\
\text { и мероприятия по обслуживанию. } \\
\text { Публичный партнер возмещает издержки } \\
\text { регулярными платежами }\end{array}$ \\
\hline
\end{tabular}

Сдерживает развитие ГЧП также отсутствие механизмов эффективного финансирования (даже при наличии средств). Общая ситуация в стране не способствует реализации долгосрочных проектов, не имеющих политической составляющей. Среди других факторов сдерживания можно отметить высокую стоимость заемных денег, нежелание банков кредитовать на длительные сроки, опасения предпринимателей браться за сложные, долгосрочные проекты. Многие из них сомневаются в сохранении стабильности в краткосрочной перспективе. Говорить о десятках лет не приходится, а именно на такой период обычно рассчитаны проекты ГЧП. Кроме того, 30-40 лет — это период глобального технологического цикла развития, в идеале совпадающего с горизонтами стратегического инвестирования.

Позволить себе участие в ГЧП сейчас могут по большей части крупные инвестиционные фонды, связанные с государством (в том числе неформально), финансировать реализацию проекта также под силу лишь государственным или квазигосударственным банкам. Большую часть крупных ГЧП-проектов можно признать в целом успешными: даже если возникают какие-то проблемы, то их всегда можно урегулировать, так как проектов немного и к ним обычно проявляется повышенное внимание властей. Однако иногда ожидания частных партнеров от реализации совместных с государством проектов не оправдываются. Так произошло, к примеру, с Олимпиадой в Сочи. Проблема в том, что бизнес, 60 
призванный властью участвовать в строительстве инфраструктуры олимпийских игр, переоценил преференции, которые ему это участие даст. Проекты готовились без должной оценки рисков: сложные природные условия, бюрократические издержки привели к значительному росту стоимости возведения объектов, которые к тому же с высокой долей вероятности не смогли себя окупить.

Что касается регионального уровня развития ГЧП, то картина не утешительна (см. табл. 4)

Таблица 4

\section{Рейтинг некоторых регионов РФ по уровню развития ГЧП на начало 2013 г.}

\begin{tabular}{c|l|c|c|l|c}
\hline № & \multicolumn{1}{|c|}{$\begin{array}{c}\text { Название } \\
\text { субъекта РФ }\end{array}$} & $\begin{array}{c}\text { Значение } \\
\text { рейтинга }\end{array}$ & № & \multicolumn{1}{|c}{$\begin{array}{c}\text { Название } \\
\text { субъекта РФ }\end{array}$} & $\begin{array}{c}\text { Значение } \\
\text { рейтинга }\end{array}$ \\
\hline 1 & Санкт-Петербург & 7,8 & 16 & Кировская обл. & 5,3 \\
\hline 2 & Татарстан & 6,6 & 17 & Ульяновская обл. & 5,3 \\
\hline 3 & Воронежская обл. & 6,5 & 18 & Ленинградская обл. & 5,0 \\
\hline 4 & Ярославская обл. & 6,3 & 19 & Карелия & 4,9 \\
\hline 5 & Тульская обл. & 6,1 & 20 & Липецкая обл. & 4,9 \\
\hline 6 & Белгородская обл. & 5,9 & 21 & Московская обл. & 4,9 \\
\hline 7 & Нижегородская обл. & 5,7 & 22 & Рязанская обл. & 4,7 \\
\hline 8 & Вологодская обл. & 5,6 & 23 & Омская обл. & 4,7 \\
\hline 9 & Калужская обл. & 5,6 & 24 & ХМАО & 4,7 \\
\hline 10 & Новосибирская обл. & 5,5 & 25 & Самарская обл. & 4,6 \\
\hline 11 & Ростовская обл. & 5,5 & \multicolumn{3}{|c}{..} \\
\hline 12 & Свердловская обл. & 5,5 & 80 & Карачаево-Черкесия & 0,0 \\
\hline 13 & Москва & 5,5 & 81 & Приморский край & 0,0 \\
\hline 14 & Красноярский край & 5,4 & 82 & Сахалинская обл. & 0,0 \\
\hline 15 & Краснодарский край & 5,4 & 83 & Чукотский АО & 0,0 \\
\cline { 2 - 5 }
\end{tabular}

Оценка складывалась из трех параметров:

1. Нормативно-правовая база в регионе, в том числе специальные структурные подразделения органов власти, ответственные за ГЧП, предусмотренные в бюджете расходы на ГЧП. 
2. Опыт реализации ГЧП (оцениваются количество проектов, их уровень и стадии реализации).

3. Кредитный рейтинг региона (количество присвоенных рейтинговых оценок, а также значение оценок).

К тому же ГЧП развивается там, где есть недостаток бюджетных средств [9]. Таким образом, системный подход к проблеме ГЧП должен предусматривать комплексное решение следующих основных задач:

1. Разработка концепции и стратегии введения ГЧП, которые должны в частности включать:

- цели, задачи и принципы создания ГЧП;

- этапы их развертывания;

- организационную структуру и систему управления, предусматривающую в первую очередь функции ее отдельных звеньев, правило «одной двери» и т. п.;

- механизм и инструменты;

- перечень законодательных актов федерального уровня в пакете, которые необходимо принять;

- федеральный орган государственной власти, ответственный за подготовку этого пакета законов и сроки исполнения.

2. Создание необходимой институциональной правовой, экономической, организационной среды:

- формирование достаточно полной и замкнутой законодательной базы по концессиям, включающей нормативные акты и подзаконные документы;

- формирование в стране других элементов институциональной среды: органов исполнительной власти, в ведении которых находятся вопросы ГЧП (в первую очередь концессий), финансово-экономических институтов, обеспечивающих инвестирование и гарантирование частных инвестиций (например, Агентство по гарантированию инвестиций), независимых организаций, осуществляющих экспертизу проектов и консалтинг, управляющих компаний, ассоциаций, объединений, фондов и т. п. 
3. Создание специального федерального органа (например, Федерального агентства по ГЧП или по концессиям), который должен реализовывать политику ГЧП в России и отвечать перед президентом, правительством и обществом за весь комплекс вопросов ГЧП. Он должен быть достаточно самостоятельной и полномочной структурой, иметь целью изучение всего спектра проблем ГЧП юридических, организационных, финансовых, экономических и подготовку методической, нормативной, правовой, инструментальной базы для развертывания и развития ГЧП в России.

4. Подготовка специалистов в области концессий, создание благоприятного общественного мнения для передачи частному сектору функций владения и пользования объектами государственной и муниципальной собственности, обеспечение доверия общественности к этому новому для современной России типу хозяйственных отношений, а также обеспечение прозрачности деятельности бизнеса. Введение ГЧП, и прежде всего концессий, по своим масштабам, глубине и степени проникновения в систему сложившихся хозяйственных отношений вполне может сравниться с приватизационными процессами, поскольку объектом партнерства в России уже в ближайшее время могут стать предприятия отраслей социально-производственной инфраструктуры. И от того, насколько полной, непротиворечивой, качественной будет законодательная база, институциональная среда, экономическая и организационная проработка всех аспектов этой проблемы, во многом зависит успех или неудача реализации этого намечающегося крупного социально-политического и экономического преобразования хозяйственных отношений в России [10].

\section{Список литературы}

1. Варнавский В.Г. Приватизационные процессы в инфраструктуре: успехи и ошибки реформ / В. Г. Варнавский // Мировая экономика и международные отношения. 2005. № 8. С. 109-113 (рецензия на кн. Reforming Infrastracture: Privatization, Regulation, and Competition. Washington D. C., 2004. P. 110).

2. Герземанн $O$. Ковбойский капитализм: Европейские мифы и американская реальность / О. Герземанн. М., 2006. 270 с. 
3. Википедия. URL: http://ru.wikipedia.org/wiki/

4. Ведущий российский портал руководства франшиз. URL: http:// www.openbusiness.ru

5. Ereport.ru. URL: http://www.webeconomy.ru

6. АО «Фонд развития предпринимательства» / «ДАМИ» : офиц. сайт. URL: http://www.damu.kz/9934

7. Національна академія управління. URL: http://www.nam.kiev.ua

8. Project Syndicate. The wordl's opinion page. URL: www. project-sindicate

9. Гагарин П. Государственно-частное партнерство: проблемы и перспективы развития / П. Гагарин // Финансовая газета. № 14. 11.04.2013.

10. Варнавский В. Г. Государственно-частное партнерство в России: проблемы становления / В. Г. Варнавский // Отечественные записки. 2004. № 6. URL: http://www.strana-oz.ru 


\section{Глава 2 \\ ГЛОБАЛИЗАЦИЯ РОССИЙСКОЙ ЭКОНОМИКИ КАК ДЕТЕРМИНАНТА ЭКОНОМИЧЕСКОГО ПОВЕДЕНИЯ РОССИЙСКИХ ПРЕДПРИЯТИЙ}

\section{§ 1. «Геополитический кризис»: барьеры и возможности для предприятий малого бизнеса}

В условиях высокой неопределенности внешней среды, связанной с текущим «геополитическим кризисом», компании неизбежно сталкиваются с проблемой создания наиболее эффективной стратегии развития, ориентированной на формирование условий устойчивого роста, направленной на снижение влияния негативных факторов и максимизацию эффекта от использования возможностей.

Эмпирическая оценка изменений стратегических и операционных действий компаний в условиях кризисов 2008 и 2014-2015 гг. дает возможность выявить специфические черты текущего кризиса и предложить институциональные, организационные, финансовые и иные актуальные формы поддержки предприятий малого бизнеса (МБ) в сложившихся условиях на основании анализа мнений самих предпринимателей.

Специфические условия развития кризисной ситуации 2014-2015 гг. в России определяются влиянием геополитических факторов, что меняет привычное представление о барьерах и возможностях развития сферы МБ в период турбулентности.

Классическая типология кризисов включает:

- экономические кризисы: отражают острые противоречия в экономическом состоянии социально-экономической системы; 
- социильные кризисы: отражают противоречия в интересах различных социальных групп;

- политические кризисы: характеризуются противоречиями в политическом устройстве социально-экономической системы, затрагивающими интересы различных социальных групп;

- психологические кризисы: это кризисы социально-психологического климата, которые наиболее ярко проявляются в периоды радикальных перемен в обществе в условиях нестабильности (примером психологического кризиса может являться кризис доверия. Это утрата доверия к финансовым и политическим структурам государства, к власти);

- организационные кризисы: проявляются как обострение отношений, связанных со структурным построением, разделением и интеграцией деятельности, распределением функций, регламентацией деятельности подразделений, административных единиц, дочерних фирм, филиалов;

- экологические кризисы: это кризисы взаимоотношений человека с природой, вызванные небрежным отношением к требованиям закона природного равновесия [1].

Глобальные угрозы, способствующие возникновению кризисов, по мнению экспертов «Всемирного экономического форума», могут быть сегментированы на пять категорий: экономические, экологические, геополитические, социальные, технологические.

В современных условиях геополитика активно влияет на экономику, поскольку экономические инструменты все чаще применяются для решения геополитических задач [2]. Геополитические процессы генерируют территориальные, этнические, национальные, религиозные, демографические изменения и трансформируют картину мира.

В современной системе международных отношений основное напряжение геополитической борьбы сместилось в сферу экономики. Наднациональные образования, отдельные государства и ТНК постоянно находятся в тесном взаимодействии и используют 66 
широкий арсенал экономических, технологических, политических и также военных мер для завоевания и удержания наиболее выгодных секторов в мировой экономике. С одной стороны, государства пытаются расширить геополитическое влияние через политику экономической интеграции, создавая торговые союзы и используя трансграничные инвестиции. С другой стороны, они используют такие инструменты, как протекционизм или экономические санкции в качестве средства принуждения. Подобные действия угрожают принципу глобального экономического сотрудничества.

«Геополитический кризис» отражает противоречия в экономических, политических, географических, военно-стратегических интересах различных участников геополитики; сопровождается обострением таких явлений, которые дестабилизируют геополитическую ситуацию в мире и, как следствие, ростом геополитической напряженности в мире. Основным фактором геополитического кризиса является обострение геополитических угроз в мире. Среди причин геополитического кризиса можно также выделить: расстройство международной финансовой системы; усиление корпоративного бизнеса при ослаблении государственного регулирования; цикличность экономического развития; «перегрев» кредитного рынка; политические действия (различные запреты, войны); геополитические конфликты и, как следствие, неустойчивость мирового экономического роста.

«Геополитический кризис» является общим, системным, глубоким, охватывает различные области жизни и имеет разрушительные последствия, такие как спад в мировой экономике; социально-экономическая напряженность; сокращение производства; безработица; падение уровня жизни; геополитическая напряженность; нарушения в денежно-кредитной и валютно-финансовой сферах.

Описанные выше тенденции можно наблюдать сейчас в российской экономике. Кризисные события прошлых лет, исторические особенности развития страны и геополитическая ситуация, сложившаяся в мире в 2014 г., привели к тому, что сейчас в экономике России происходит наложение сразу нескольких негативных 
процессов [3]. Один из этих процессов связан с ростом геополитической напряженности в мире, введением санкции в отношении России, бремя которых проявляется в данном случае не только в том, что российские компании оказались отрезаны от мировых капиталов, но и в том, что это сопровождается ростом недоверия к российской экономике, ростом неопределенности условий ведения бизнеса на территории РФ. Это замедляет и откладывает многие проекты, снижает рост инвестиционной активности и заставляет иностранные компании пересматривать свою деятельность на территории государства.

В условиях «геополитического кризиса» компаниям все чаще приходится сталкиваться с непредвиденными рисками вследствие постоянно изменяющейся политической обстановки, введения санкций, различных эмбарго и других, непрогнозируемых заранее рисков. Как следствие риски, которые несет в себе подобная кризисная ситуация характеризуются большим многообразием, различаются по месту и времени их возникновения, продолжительности и степени воздействия, совокупностью внешних и внутренних факторов, влияющих на уровень и меру чувствительности к ним.

Среди основных рисков можно выделить следующие:

- политические риски, возникающие как результат изменения государственной политики (риски неблагоприятных социально-политических изменений в стране, безработица, терроризм). В этом аспекте можно выделить социально-экономические риски - риски неблагоприятного социального климата организации, банкротства, проведения политики ценообразования, невыгодного поглощения одного предприятия другим и т. д.;

- экономические риски связаны с потерей прогнозируемого результата вследствие инфляции, изменения конвертируемости национальной валюты и т. д. (изменение государственного регулирования в сфере налогообложения, экспортаимпорта, внешнеэкономической деятельности; риски потери доходности организации, снижения цен на реализацию 
продукции; риски потери активов организации, снижения ликвидности и финансовой устойчивости организации);

- производственные риски обоснованы государственным регулированием развития конкретных отраслей, предприятий или регионов (протекционистские меры, утрата производственных мощностей вследствие изменения потребностей рынка сбыта или снижения качества производимого товара);

- маркетинговые риски обусловлены изменением рынков сбыта продукции, коммуникационными рисками, появлением новых конкурентов или появлением товаров-субститутов и проч.

Кризисы не только создают барьеры, но обозначают возможности для компаний: новые подходы к деятельности. Кризисные ситуации могут стать толчком для изменений в целях и миссии, облике и масштабах компании, реорганизации; пересмотра отношения к доминирующим представлениям о рынке и существующим способам ведения бизнеса. Риски потери прогнозируемого результата, снижения доходности организации побуждают компании к пересмотру и оптимизации затрат, потоков денежных средств от деятельности. Результатом изменения государственной политики могут быть новые возможности для компании в контексте получения поддержки со стороны государства: государственные гарантии по кредитам, субсидирование, государственные заказы и т. п.; ограничения по импорту продовольствия дают шанс увеличения собственного эффективного производства качественной продукции; возникаю возможности взаимодействия с государством по каким-либо взаимовыгодным процессам.

В условиях социально-экономической напряженности в обществе компания может проявить себя в рамках КСО: завоевать доверие общественности, с помощью акцентирования внимания на заботе компании о благополучии местных поставщиков и агентов, за счет спонсорства местных мероприятий и т. п. 
Риски потери рынков сбыта продукции заставляют компании искать новые каналы распределения, пересматривать ценовую политику компании, искать новые идеи для рекламы, согласно меняющимся предпочтениям потребителей, проводить акции и другие стимулирующие продажи мероприятия.

В результате корректировки своей стратегической деятельности компании могут открыть для себя новые пути действий:

- использование совершенно новых продуктов или новой версии существующего товара (ускорить цикл замены товара);

- применение новых способов использования и продвижения существующих товаров (поиск перспективных направлений применения);

- поиск новых рынков (вход в рыночный сегмент, который не рассматривался как выгодный или игнорировался);

- использование нетрадиционных, новых способов ведения конкурентной борьбы.

Кроме того, всегда есть вариант ликвидация или замораживания бизнеса и инвестирования вырученных денег в более выгодные проекты.

Как было отмечено выше, в 2015 г. Россия оказалась в трудном кризисном положении. История экономики и политики Российской Федерации начинается после событий 1990-1992 гг., когда произошел распад СССР и были осуществлены реформы, создавшие основы рыночной экономики. С тех пор произошло много событий и изменений во всех сферах деятельности государства. Можно выделить три этапа развития экономики России (рис. 2).

После кризисных явлений первого этапа развития экономики России восстановительный рост опирался на силы новой экономики и на ренту от повышения цен на нефть и газ. Однако темпы роста производительности стали снижаться еще накануне 2008 г., и мировой кризис 2008-2009 гг. обозначил конец второго этапа развития российской экономики и начало «нового этапа». 


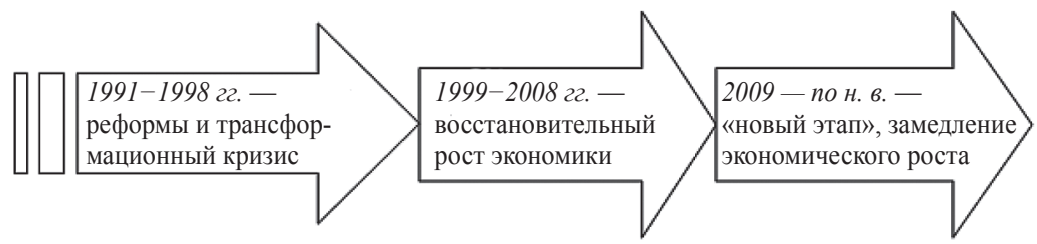

Рис. 2. Этапы развития экономики России с 1991 г. по настоящее время (составлено автором по: Н. В. Акиндиновой, Е. Г. Ясину [4, с. 35])

Особенность кризиса 2008-2009 гг. заключалась в его общемировом характере. В сентябре 2008 г. вслед за крахом крупнейших банков в США началось сжатие финансовых рынков по всему миру, отток капитала из большинства развивающихся экономик на фоне роста общей неопределенности и риска по всем экономикам мира. Кризисные явления в России стали следствием мирового глобального кризиса - сказался эффект переноса кризиса. Вместе с тем глобальный кризис для России оказался относительно краткосрочным отчасти в силу того, что цены на нефть - один из ключевых показателей для экономики России — в конце 2009 г. вернулись на «комфортный» уровень, правительством были реализованы антикризисные меры, в основе которых лежало использование накопленных ранее резервов [5]. Однако спад 2009 г. на 7,8 \% и последовавшее восстановление 2010-2011 гг. не привели к продолжению роста 2000-х гг. и далее снова началось снижение темпов роста экономики РФ [6].

В период 2011-2014 гг. происходило накопление политических и институциональных изменений, что выражалось в усилении влияния государства на экономику страны (увеличение налоговой нагрузки, рост влияния силовых структур, увеличение контроля за поведением экономических агентов и др.). Кроме того, в стране прошли парламентские и президентские выборы в 2011 и 2012 г,, соответственно исход проведения которых вызвал противоречия между разными группами общества и протестные движения в различных городах России. 
В итоге к началу 2014 г. в российской экономике накопились негативные тенденции, ставшие следствием неразрешенных в предыдущие годы проблем:

- недоверие бизнеса и низкая деловая активность;

- переход экономики к стагнации в условиях опережающего роста потребления и спада инвестиций;

- отток капитала;

- разрастание в экономике неэффективного государственного сектора, при ослаблении рыночных и правовых институтов [7].

Ситуацию обострил геополитический фактор. В феврале 2014 г. в качестве реакции на присоединение Крыма и ситуацию на востоке Украины Западные страны ввели санкции в отношении России (ограничительные политические и экономические меры).

В ответ на санкции Россия ограничила импорт отдельных видов сельскохозяйственной продукции, сырья и продовольствия из стран, которые ввели в отношении нее санкции. Введение эмбарго привело к росту цен на попавшие под контракции товары, к ухудшению потребительского ассортимента и породило дополнительные трансакционные издержки для российских предприятий.

По мнению Минэкономразвития РФ, российская экономика на современном этапе столкнулась одновременно с действием структурного, конъюнктурного и геополитического кризисов. Сложившаяся кризисная ситуация характеризовалась повышенной внешнеэкономической неопределенностью и геополитической напряженностью во всем мире. Главные угрозы экономики России - это остановка экономического роста, инфляция, отток капитала, нестабильные цены на нефть, в меньшей степени на данный период актуален риск неуправляемого падения курса рубля [8].

Кризисная ситуация влечет негативные социальные последствия: падение реальных доходов населения, рост безработицы, ухудшение условий кредитования, рост стоимости товаров и услуг 
и т. д. В свою очередь, мировые компании, ведущие бизнес в России, теряют прибыль из-за сокращения потребительской активности населения, а часть из них сообщила о выводе своего капитала из России.

Нестабильность внешней окружающей среды - критичный фактор для развития малого бизнеса, однако именно МП демонстрируют высокий уровень адаптивности к изменяющимся внешним условиям. На основании эмпирических исследований (Мониторинг «Малый бизнес: барьеры и возможности в условиях кризиса», стандартизированные интервью с директорами предприятий малого бизнеса; 1-й этап: август-ноябрь 2008 г., $N=78$; 2-й этап: апрель-май 2015 г., $N=76$, стратифицированная выборка; организатор - кафедра теории и практики менеджмента ВШЭМ, УрФУ) были изучены актуальные аспекты влияния кризиса 2008 и 2015 гг. на функционирование малого бизнеса, стратегические преференции компаний в условиях нестабильности (табл. 5).

По результатам 1-го этапа мониторинга очевидна высокая степень зависимости предприятий МБ от кризисного влияния.

Прежде всего были затронуты предприятия, взаимодействующие с компаниями банковской, строительной и производственной сфер и функционирующие непосредственно в этих областях (группа составляет около $45 \%$ ).

Средняя оценка влияния кризиса в данных компаниях составила 3,2 по 5-балльной шкале (где 1 - кризис практически не повлиял, 2 - повлиял, но незначительно, 3 - оказал существенное влияние, 4 - компания вынуждена полностью пересмотреть свою стратегию, 5 - фирма находится на грани банкротства). Средняя по всему массиву (2,8 балла) оценка акцентирует значимое влияние кризиса на деятельность предприятий МБ, но не обозначает генеральной смены стратегий ведения бизнеса или банкротства компаний. Модальное значение 3. 
Таблицуа 5

Мониторинг «Малый бизнес: барьеры и возможности в условиях кризиса». Структура выборочной совокупности ${ }^{1}$

\begin{tabular}{|c|c|c|c|c|}
\hline Отрасль & $\mid \begin{array}{c}\text { Доля малых } \\
\text { предприятий } \\
2007 \text { г., \% уд. } \\
\text { распр. ВВП, МБ }\end{array}$ & \begin{tabular}{|c|} 
Доля малых \\
предприятий \\
2012 г., \% уд. \\
распр. ВВП МБ
\end{tabular} & $\begin{array}{l}\text { Структура } \\
\text { выборки, } \\
2008 \text { г., } \\
\text { абс. числа }\end{array}$ & $\begin{array}{c}\text { Структура } \\
\text { выборки } \\
2014 \text { г. абс. } \\
\text { числа }\end{array}$ \\
\hline $\begin{array}{l}\text { Сельское и лесное } \\
\text { хозяйство, } \\
\text { рыболовство }\end{array}$ & 2 & 3 & 1 & 2 \\
\hline $\begin{array}{l}\text { Добыча полезных } \\
\text { ископаемых }\end{array}$ & 0 & 2 & 0 & 2 \\
\hline $\begin{array}{l}\text { Обрабатывающая } \\
\text { промышленность }\end{array}$ & 2 & 2 & 1 & 1 \\
\hline $\begin{array}{l}\text { Производство } \\
\text { и распределение } \\
\text { электроэнергии, } \\
\text { газа и воды, прочие } \\
\text { коммунальные услуги }\end{array}$ & 0 & 4 & 0 & 3 \\
\hline Строительство & 15 & 12 & 11 & 7 \\
\hline Торговля & 24 & 28 & 19 & 23 \\
\hline Транспорт и связь & 4 & 3 & 3 & 3 \\
\hline Финансы и услуги & 32 & 27 & 25 & 22 \\
\hline $\begin{array}{l}\text { Образование, } \\
\text { госуправление, } \\
\text { здравоохранение } \\
\text { и военная } \\
\text { безопасность }\end{array}$ & 21 & 19 & 16 & 15 \\
\hline Итого: & 100 & 100 & 76 & 78 \\
\hline
\end{tabular}

Общие негативные факторы, оказывающие влияние на деятельность малых предприятий в 2008 г. и актуальные для

${ }^{1}$ Расчет выборки на основании удельного распределение ВВП РФ по отраслям и размерам предприятий с учетом доли малого, среднего и крупного бизнеса. 
большинства российских компаний, отмечены 86 \% опрошенных топ-менеджеров:

1. Снижение ликвидности.

2. Неплатежи.

3. Низкая инвестиционная активность.

Основные факторы негативного влияния в 2008 г., оказавшие влияние на различные аспекты деятельности предприятий, задействованных в исследовании: снижение платежеспособного спроса на товары и услуги малых предприятий; сокращение банками программ кредитования малого бизнеса; снижение деловой активности предпринимателей в связи с неопределенной экономической ситуацией.

По результатам анализа материалов исследования, в том числе ответов на открытые вопросы, можно отметить, что кризисные явления в экономике в 2008 г. оказывали следующее влияние на планы стратегической деятельности субъектов малого предпринимательства:

1) была выявлена тенденция замораживания проектов, которые были направлены на развитие и расширение (приостанавливались покупка нового оборудования, вложения в инфраструктуру, наем и обучение персонала, освоение новых земельных участков, открытие новых торговых точек, совершенствование методов управления, организации производства и сбыта и т. п.);

2) предприятия старались сокращать инвестиционные и налоговые расходы;

3) пересматривались методы работы с контрагентами (например, предприятия отказывались от предоплаты на покупаемый товар и предъявляли более серьезные требования к покупателям, чтобы избежать возможности неплатежей за отгруженную продукцию);

4) поскольку доступ к кредитным услугам легального рынка кредитования был ограничен, происходило привлечение заемных средств с нелегальных кредитных рынков (от ростовщиков и криминальных кредитных касс). 
В результате интервью с руководителями предприятий в 2015 г. удалось выявить основные бизнес-риски, вызывающие беспокойство МБ в условиях «геополитического кризиса». В качестве общих для всех сфер бизнеса были названы (74\% опрошенных):

1. Нестабильная экономическая ситуация.

2. Неопределенность перспектив ведения бизнеса на территории РФ.

3. Взяточничество и коррупция.

4. Высокие или волатильные цены на энергоносители.

5. Сбои в цепочке поставок.

6. Киберугрозы, включая недостаточную защиту данных.

7. Высокие темпы технологического прогресса.

Сравнивая риски с обозначенными в период 2008 г., следует отметить, что предприниматели актуализируют не только факторы, связанные с экономическим развитием, но и факторы, характеризующие специфические условия функционирования бизнеса в стране и за рубежом. «Геополитический» кризис на 2-м этапе мониторинга актуализирует «глобальную среду» реализации бизнес-процессов.

Средняя оценка влияния кризиса в условиях 2014-2015 гг. составила 2,9 по 5-балльной шкале (где 1 - кризис практически не повлиял, 2 - повлиял, но незначительно, 3 - оказал существенное влияние, 4 - компания вынуждена полностью пересмотреть свою стратегию, 5 - фирма находится на грани банкротства). Средняя по всему массиву (2,2 балла) оценка акцентирует менее значимое влияние кризиса на деятельность предприятий МБ, нежели в условиях 2008 г. Модальное значение 2.

Среди факторов, влияющих непосредственно на малый бизнес, названы:

1. Нехватка квалифицированных кадров (около 2/3 респондентов).

2. Изменения в расходах и поведении потребителей (65 \%).

3. Отсутствие доверия к бизнесу (49\%).

4. Неопределенность конкурентной ситуации, появление на рынке новых игроков (44\%).

5. Проблемы платежеспособности юридических лиц (38%). 
К общим экономическим угрозам ведения бизнеса добавилась проблема роста неопределенности условий ведения бизнеса на территории РФ: в условиях «геополитического кризиса» компаниям все чаще приходится сталкиваться с непредвиденными рисками вследствие постоянно изменяющейся политической обстановки (40 \% топ-менеджеров), введения санкций (64 \% опрошенных), различных эмбарго и других, непрогнозируемых заранее рисков (около $30 \%$ ).

Руководители часто упоминали такие угрозы, как повышение финансового бремени (каждый пятый), социальная нестабильность (около трети), отсутствие доступа к капиталу (40 \%), неразвитость базовой инфраструктуры (15\%), высокая или частичная безработица (32\%).

Так же как в 2008 г., в текущий период компании проводят мероприятия по сокращению затрат, стимулированию продаж, оптимизации денежных потоков и ищут для себя пути увеличения доходов за счет диверсификации бизнеса. Диверсификация бизнеса остается источником сохранения бизнеса в кризисных условиях.

На основе опроса владельцев МБ деятельность их предприятий характеризуется в период геополитического кризиса 2014-2015 гг. (табл. 6):

Таблица 6

\section{Факторы, характеризующие деятельность компаний МБ} в условиях геополитического кризиса

\begin{tabular}{l|c}
\hline \multicolumn{1}{c|}{ Фактор } & $\begin{array}{c}\text { Процент к числу } \\
\text { опрошенных }\end{array}$ \\
\hline Увеличение расходов & 90 \\
\hline Сокращение объема заказов/спроса & 74 \\
\hline $\begin{array}{l}\text { Кризисные явления заставили углублять знания } \\
\text { о состоянии рынка, пересматривать планы } \\
\text { реализации стратегии }\end{array}$ & 24 \\
\hline $\begin{array}{l}\text { Произошло увеличение стоимости закупок } \\
\text { импортных товаров и комплектующих }\end{array}$ & 19 \\
\hline Увеличилось число долгов клиентов за услуги &
\end{tabular}


В результате реакции на данные тенденции в первом квартале 2015 г. удалось выявить основные тенденции изменений в стратегической деятельности предприятий МБ:

- компании все чаще прибегают к диверсификации бизнеса;

- компании стали ориентироваться на развитие высокоприбыльных сегментов бизнеса;

- начало кризиса подтолкнуло к увольнению сотрудников, оптимизации руководства, появились сотрудники-фрилансеры, компании отдают часть производства и услуг на аутсорсинг;

- сокращение спроса привело к появлению новых специальных предложений, скидок, акций, к разработке особых программ сотрудничества с постоянными клиентами;

- активно практикуется сокращение издержек, реализуется работа по снижению дебиторской задолженности; компании осуществляют поиск новых производителей, поставщиков с более выгодными ценами; сократилось участие в выставках и event-мероприятиях; сведены к минимуму затраты на развитие, «принцип сейчас - это сохранить то, что имеется, как деловые связи, так и коллектив»; компании заявляют, что стараются экономить расходы на нерентабельных подразделениях и фокусировать весь поток клиентов в один сервис; многие компании заявили, что стараются применять стратегию минимизации издержек, чтобы по возможности снизить цены в условиях кризиса и привлечь большее количество покупателей;

- компании ориентируются на увеличение мощностей по количеству клиентов и рост качества предоставляемых услуг путем использования маркетинговых исследований;

- многие компании временно прекратили производство нового ассортимента, сосредоточились на уже известном и разработанном;

- для многих компаний стало актуально замещение различных товаров (комплектующих) на отечественные аналоги; 
- многие компании заявили, что прибегли к использованию на прилавках товаров «эконом» (китайский ассортимент);

- изменились подходы к рекламе, предпочтение отдается к более экономичным видам рекламы, рекламу делают с учетом кризиса («есть баннер, на котором написано, что в нашем магазине можно приобрести продукцию российского производителя»).

Однако многие компании (17 \%) заявили, что общее направление развития компании осталось без изменений и кризис не оказал существенного влияния на их деятельность.

В условиях введения государством протекционистских мер большое значение для МБ играет поведение на российском рынке зарубежных компаний. Геополитическая напряженность и высокий уровень неопределенности сыграли большую роль в настроениях и ожиданиях руководителей крупнейших компаний, для половины компаний (54 \%) Россия остается ключевым рынком в регионе CEEMEA (Центральная и Восточная Европа, Ближний Восток и Африка). На фоне геополитической нестабильности и замедления роста экономик в 2015 г. большая часть СЕО со всего мира планируют реализовать инициативы по сокращению затрат. В то же время в предстоящие 12 месяцев планируют провести различных слияния и объединения как на национальном, так и международном уровнях. О создании нового стратегического альянса или совместного предприятия заявили 51 \% СЕО во всем мире, о слиянии или поглощении на национальном уровне - $29 \%$, на международном уровне - $27 \%$. Активно передавать на аутсорсинг бизнес-процессы или функции планируют 31 \% опрошенных руководителей в мире. Важно заметить, что продажу контрольного пакета акций компании или уход с важного рынка планируют 18 \% СЕО из Западной Европы и 23 \% СЕО из США [9]. В связи с данными тенденциями российским предприятия МБ открывается возможность освоения ниш, освободившихся за счет сворачивания бизнеса зарубежных компаний и компаний-конкурентов. 
Таким образом, в результате геополитического кризиса положение МБ ухудшилось, что связано:

1) с финансовыми проблемами (сокращение оборотных средств, снижение доступа к банковским кредитным услугам, государственной финансовой поддержке);

2) рисками снижения ликвидности;

3) рисками неплатежей контрагентов;

4) снижением платежеспособного спроса и как следствие снижение оборачиваемости капитала, нормы прибыли и рентабельности.

Опрашиваемые отмечают, что при невмешательстве государства в решение проблем малого бизнеса очень высока вероятность существенного сокращения малых предприятий, увеличения безработицы, ухода в «тень» оборотных средств, сокращением доходной части региональных и местных бюджетов. Пока предприниматели не видят перспективных и актуальных форм поддержки и прогнозируют возможное «свертывание» данного сектора в условиях «геополитического кризиса». Такие масштабные оценки тенденции кризиса не отмечались в период 2008 г. С другой стороны, текущая ситуация не провоцирует активное реагирование компаний. Если в 2008 г. более 80 \% опрошенных отмечали, что бизнес претерпевает существенные изменения и в ближайшей перспективе может быть «свернут», то при оценке текущего «геополитического» кризиса предприниматели видят перспективы для развития в политике импортозамещения, переструктурировании рынка за счет «ухода» импортоориентированных компаний и зарубежных игроков.

Можно выделить специфические стратегические тренды. Так, в период 2008 г. стратегии диверсификации, развития бизнеса, усиления клиентоориентированных программ рассматривались как актуальные только компаниями, имевшими опыт «выживания» в кризисе 1998 г. и находившимися на стадии зрелости. В ситуации текущего кризиса такие действия активно декларируются как актуальные и своевременные большинством участников опроса, независимо от стадии ЖЦ и антикризисного опыта. 
Патерналистские тенденции, характерные для российского бизнеса, в большей степени актуализировались также в период 2008 г. Тогда участники опроса декларировали необходимость введения мер поддержки на государственном (75 \%), региональном (около 50 \%) уровне. В текущем кризисе компании не ждут, «когда приедет барин», только 1 из 6 руководителей малого бизнеса видит в поддержке на государственном уровне панацею. Возможно, такое положение дел связано с тем, что компании видят как «разваливается» инфраструктура организаций, поддерживающих МБ (24 \%). Но этот факт может свидетельствовать и о том, что традиционный патернализм теряет значение, и МБ становится более самостоятельным, не ждет помощи и решает проблемы, исходя из собственных ресурсов и возможностей. В такой ситуации возможности, связанные со спецификой геополитического кризиса, могут способствовать развитию сферы предпринимательства.

В период 2008 г. большинство предпринимателей отмечали высокую уязвимость всего сектора малого бизнеса в условиях кризиса. В текущей ситуации предприниматели выделяют менее уязвимые к кризису предприятия (80\% респондентов) (табл. 7).

Таблииа 7

\section{Характеристика предприятий, менее чувствительных к кризису 2014-2015 гг.}

\begin{tabular}{l|c}
\hline \multicolumn{1}{c|}{ Характеристика предприятия МБ } & $\begin{array}{c}\text { Процент к числу } \\
\text { ответивших }\end{array}$ \\
\hline $\begin{array}{l}\text { Работающие без привлечения дополнительного } \\
\text { кредитования }\end{array}$ & 55 \\
\hline $\begin{array}{l}\text { Предлагающие продукцию и услуги по низким ценам или } \\
\text { готовые предоставить дополнительные скидки, бонусные } \\
\text { программы }\end{array}$ & 21 \\
\hline $\begin{array}{l}\text { Производящие (продающие) продукцию с неэластичным } \\
\text { спросом }\end{array}$ & 16 \\
\hline Ориентированные на импортозамещение & 12 \\
\hline $\begin{array}{l}\text { Имеющие наработанную и лояльную клиентскую базу, } \\
\text { стабильные заказы }\end{array}$ &
\end{tabular}


В ситуации кризиса 2008 г. каждый второй предприниматель отмечал бесперспективность создания МП, в текущем кризисе только $10 \%$ руководителей предприятий МБ считают нецелесообразным открывать собственный бизнес и около половины считают, что текущая ситуация дает «хорошие шансы», которые можно использовать, «если вы умеете работать и думать».

\section{Список литературы}

1. Авдошина 3. А. Антикризисное управление: сущность, диагностика, методики / 3. А. Авдошина // Планово-экономический отдел. 2012. № 7. C. 3-10.

2. Всемирный экономический форум назвал 2015-й годом геополитических рисков // РБК. [Электронный ресурc]. URL: http://rbcdaily.ru/ economy/562949993675518.

3. Я бы не назвал текущую ситуацию экономическим кризисом // Фонд Егора Гайдара. [Электронный ресурс]. URL: http://readings. gaidarfund.ru/articles/2232.

4. Акиндинова Н. В. Новый этап развития экономики в постсоветской России : докл. к XVI Апр. междунар. науч. конф. по проблемам развития экономики и общества. Москва, 7-10 апр. 2015 г. / Н. В. Акиндинова, Е. Г. Ясин ; Нац. исслед. ун-т «Высшая школа экономики». М. : Изд. дом Высшей школы экономики, 2015. 35 с.

5. Там же. С. 35.

6. Там же. С. 21.

7. Кудрин А. Новая модель роста для российской экономики / А. Кудрин, Е. Гурвич // Вопросы экономики. 2014. № 12. С. 4-36.

8. Алексей Ведев о современных проблемах и вызовах российской экономики // Минэкономразвития России. [Электронный ресурс]. URL: http://economy.gov.ru/wps/wcm/connect/economylib4/designelements.

9. Российский выпуск 18-го Ежегодного опроса руководителей крупнейших компаний мира 2015 год // PwC. [Электронный ресурc]. URL: www.pwc.ru/ceosurvey/18. 


\section{§ 2. Возможности использования \\ китайской экспансии для развития экономики \\ Свердловской области}

На фоне непрерывного роста экономики Китая и его курса на мировую экспансию объем китайских прямых иностранных инвестиций (ПИИ) за прошедшее десятилетие вырос практически с нулевой отметки до более чем 100 млрд долл. США. В отличие от мирового объема ПИИ, который ежегодно сокращался на 8 \% с 2011 по 2014 г., среднегодовой темп роста ПИИ из Китая достиг 16 \%. В 2014 г. китайские инвесторы вложили средства в 6128 зарубежных компаний из 156 стран и регионов, благодаря чему страна третий год подряд занимает третье место в мире по объему внешних ПИИ. Их совокупный объем составил 116 млрд долл. США, что обеспечило рост на 15,5 \% по сравнению с 2013 г. (рис. 3).

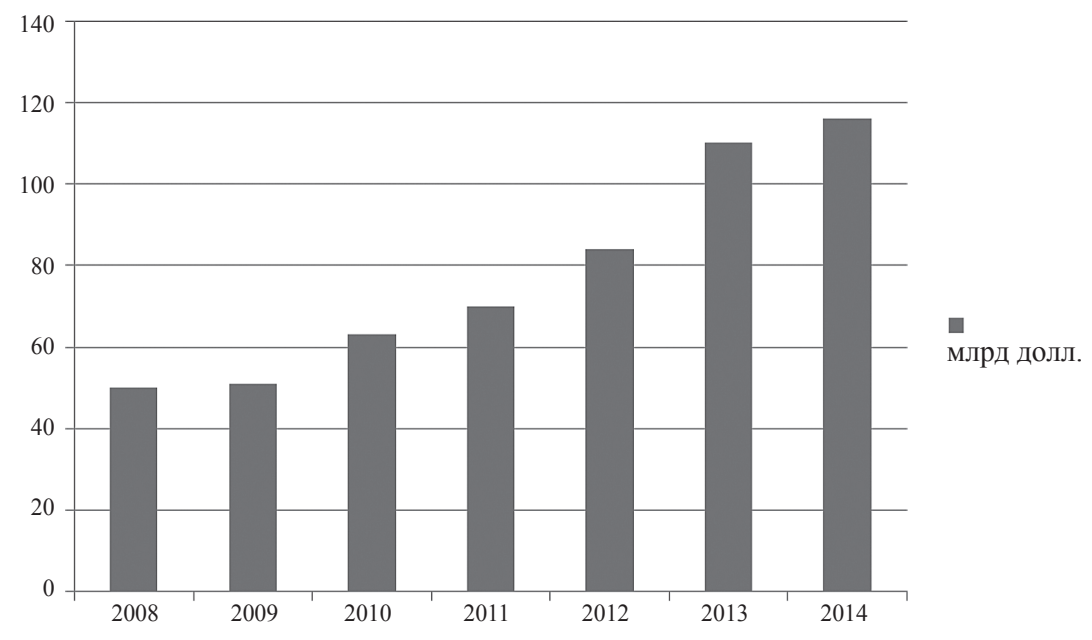

Рис. 3. Динамика китайских ПИИ в 2008-2014 гг., млрд долл. США

Источник: составлено авторами на основе данных отчета EY «Обзор китайских инвестиций на зарубежных рынках». 
Если рассматривать ПИИ Китая с 2012 по 2013 гг., вложенные в российскую экономику, то динамика инвестиций резко растущая (рис. 4).

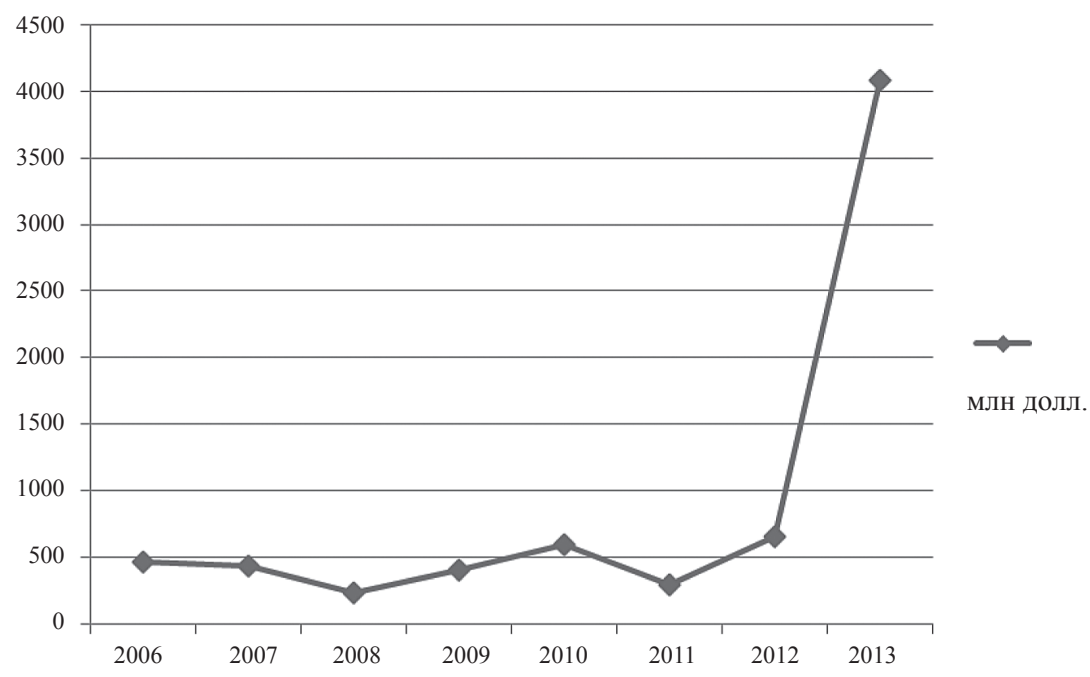

Рис. 4. Прямые иностранные инвестиции КНР в Россию, млн долл. США

Источник: составлено авторами на основе данных Министерства экономического развития РФ.

Необходимо отметить, что, по мнениям аналитиков ЕY, «по мере трансформации и укрепления национальной экономики, а также роста китайского бизнеса инвестиционный интерес перемещается с приобретения факторов производства, например ресурсов, в сторону передовых технологий и известных брендов. Китайские инвесторы меняют приоритеты с целью повышения конкурентоспособности на международной арене, а также в ответ на изменения в поведении местных потребителей. На фоне этой тенденции география китайских инвестиций существенно расширилась (рис. 5). Сегодня она уже включает развитые страны Европы и Америки и не ограничивается азиатскими, африканскими 
и латиноамериканскими странами, обладающими значительными природными ресурсами. Кроме того, китайские компании не преминули воспользоваться медленными темпами восстановления экономики развитых стран после финансового кризиса 2008 года, который отразился на стоимости их активов» [1].

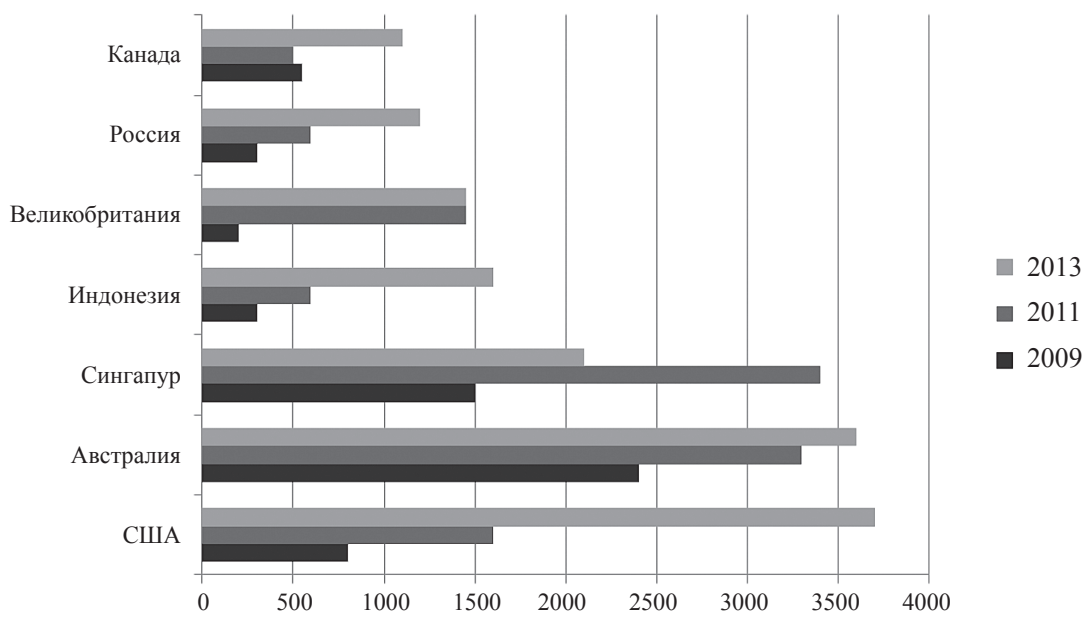

Рис. 5. Топ-7 направлений для китайских инвестиций, млн долл. США

Источник: составлено авторами на основе доклада отчета ЕY «Обзор китайских инвестиций на зарубежных рынках», данные приведены без учета Гонконга, Каймановых островов и Виргинских островов.

Однако главными направлениями инвестиционной деятельности КНР в России по-прежнему являются разработка полезных ископаемых, лесоперерабатывающее производство и энергетика. «Крупнейшими вложениями китайских компаний в российские активы стали: покупка Китайской национальной нефтегазовой корпорацией 20 \% акций в проекте “Ямал-СПГ” у компании “Новатэк”; покупка Китайской инвестиционной корпорацией 12,5\% акций "Уралкалия"; вложение Китайской международной инженерно-строительной компанией цветной металлургии (NFC) в совместный проект с корпорацией "Металлы Восточной Сибири" 
в Республике Бурятия; инвестиции Государственной электросетевой корпорации Китая в совместные проекты с российской ГК “Синтез”; приобретение Китайской инвестиционной корпорацией 5,4 \% акций Московской биржи; приобретение Строительным банком Китая $2 \%$ акций банка ВТБ» [2].

Проанализировав информацию о размере ПИИ Китая в Россию и основных российско-китайских соглашениях, можно прийти к выводу о том, что Китай и в дальнейшем будет активно инвестировать в Россию. Это может объясняться многими причинами и особенностями. Во-первых, стремление Китая сохранить свои ресурсы, хорошие темпы роста, позволяют компаниям не экономить на приобретении необходимых ресурсов в нашей стране. Во-вторых, хорошая государственная поддержка при размещении предприятий в зарубежных странах также подталкивает компанию к размещению производства за рубежом. В-третьих, в сложившейся геополитической ситуации Россия вынуждена теснее сотрудничать с КНР. Также необходимо отметить, что новая стратегия экономического развития Китая «Один пояс - один путь», принятая в начале 2015 г. [3], предполагает создание инфраструктуры и налаживание взаимосвязей с соседними странами, в которые китайские инвесторы планируют переносить производственные мощности и технологии.

Таким образом, на основе прогнозов аналитиков можно смело предположить дальнейшую активную интернационализацию китайских компаний на российский рынок. Экспансия китайских предприятий на протяжения долгого периода будет только расти, и это может помочь российской экономики выйти из кризиса и продолжить развитие за счет активных инвестиций. С этим фактом коррелируются задачи экономического развития, например Свердловской области (Стратегия-2020):

- улучшение позиций по объемам иностранных и отечественных инвестиций в экономике, вхождение в пятерку регионов-лидеров;

- вхождение в тройку лидеров по уровню развития транспортно-логистического комплекса. 
При этом приоритетами в развитии инфраструктурно-логистического комплекса являются: продолжение работ по модернизации и техническому перевооружению объектов транспорта; выполнение мероприятий по дальнейшему улучшению состояния эксплуатируемых автомобильных дорог и железнодорожных путей; достижение международных стандартов качества в оказании транспортных услуг населению и т. д. [4].

Правительство Свердловской области намерено развивать инфраструктуру не только за счет бюджетных средств, но и за счет крупного бизнеса. При этом со стороны Китая важным аргументом в желании вкладывать средства в инфраструктуру России, и в частности в инфраструктуру Свердловской области, является решение о строительстве «Нового шелкового пути» [5], который пройдет через территорию России и новая стратегия экономического развития Китая «Один пояс - один путь», принятая в начале 2015 г.

В связи с этим для экономики Свердловской области появляются возможности для привлечения прямых зарубежных инвестиций в секторы транспортной логистики и строительства со стороны китайских компаний.

Если мы будем иметь много интересных и реальных проектов, которые будут представлены китайским компаниям, возможно, мы сможем избежать прямой конкуренции на территории Свердловской области и привлечем более выгодные и «длинные» инвестиции в важные для нашего стратегического развития отрасли.

\section{Список литературы}

1. Обзор китайских инвестиций на зарубежных рынках.URL: http:// www.ey.com/RU/ru/Newsroom/News-releases/EY-news-china-outboundinvestment-report-rus

2. Основные итоги инвестиционного сотрудничества России и Китая. URL: http://www.ved.gov.ru/exportcountries/cn/cn_ru_relations/ cn_rus_projects/

3. Россия и Китай. Преодолевая границы. URL: http://www. rg.ru/2015/05/08/kitay.html 
4. Стратегия социально-экономического развития Свердловской области на период до 2020 года / ПСО 29.12.2010 г. URL: http://economy. midural.ru/sites/default/files/documents/aktual_strategy2020.pdf

5. Новый Шелковый путь пройдет через Россию/ Актуальные комментарии. 10.03.2015 г. URL: http://actualcomment.ru/novyy-shelkovyyput-proydet-cherez-rossiyu.html 


\section{Глава 3 \\ СТРАТЕГИИ РАЗВИТИЯ РОССИЙСКИХ ПРЕДПРИЯТИЙ В УСЛОВИЯХ КРИЗИСА}

\section{§ 1. Сессия организационного развития как платформа генерации прорывных идей в бизнесе ${ }^{1}$}

Определяясь для начала с терминологией, сессией организациионного развития мы могли бы считать судьбоносную для компании встречу ее ведущих руководителей, максимально заинтересованных в выходе этой компании на принципиально новый уровень своего функционирования. Целью такой встречи становится стратегическое планирование, связанное с реализацией некоего масштабного бизнес-проекта либо с внедрением инновационной технологии. Сессия организационного развития чем-то напоминает джазовую импровизацию: она представляет собой каскад нетривиальных идей и подходов, позволяющих с оптимизмом заглянуть в будущее бизнеса. И вполне очевидно, что во время таких обсуждений иррациональное неизбежно переплетается с рациональным. Принципиальное отсутствие каких-либо алгоритмов и ограничений сочетается с технологическим подходом и следованием пошаговым инструкциям. Творческий инсайт (озарение), который, казалось бы, никак нельзя запрограммировать заранее, становится возможным в результате применения подробной технологической карты.

${ }^{1}$ См.: Петров А. Ю., Петров Е. А. Генерация прорывных идей в бизнесе. M., 2015. 368 c. 
В какие же периоды своего развития бизнес особенно остро нуждается в прорывных идеях? Они необходимы буквально на каждом из этапов жизненного цикла компании, а именно: на этапе создания - для того чтобы заложить фундамент компании; на этапе бурного роста — для того чтобы найти наиболее прибыльную нишу; на этапе зрелости - для повышения эффективности бизнес-процессов; и, наконец, на этапе кризиса - для выведения компании из крутого пике на принципиально новый виток развития.

Переходя к возможным сценарным формам проведения сессий организационного развития, следует заметить, что в профессиональном сообществе фасилитаторов и бизнес-тренеров в настоящее время широко применяется следующая пошаговая модель: настраиваясь на групповую дискуссию, необходимо отдать предпочтение одному из двух возможных вариантов маршрута. С помощью фасилитатора группе предстоит совершить принципиальный выбор, определяющий философию и стилистику дальнейшего обсуждения бизнес-проблем: групповая дискуссия может пойти через «видение будущегг» при условии единого понимания идеального конечного результата. Другой, альтернативный маршрут может определяться движением через анализ дня сегодняшнего при условии единого понимания актуальных для компании сильных сторон и зон роста.

Таким образом, выделяются следующие четыре сценария сессии организационного развития:

1. «Форс-мажор». Принципиально не заглядывая в будущеее, выбираем маршрут через актуальный анализ сегодняшнего дня и далее $\rightarrow$ к принятию решения. Показания к применению: команда неожиданно сталкивается с чрезвычайно острой сиюминутной проблемой, между тем имеющиеся ресурсы для ее решения (люди, время, финансы) крайне ограничены. Стоящая проблема настолько остра, что не позволяет думать о будущем («Не до этого!»). Цель сессии: найти наиболее эффективное средство решения проблемы в кратчайшие сроки. Риски: принятие локальных тактических решений в ущерб общей стратегии. 
2. «Креатив без оглядки». Выбираем путь, отталкиваясь от видения будущего и далее $\rightarrow$ к принятию решения, принципиально игнорируя анализ сегодняшнего дня. Показания к применению: свобода и независимость от рутинных повседневных задач («Наконец-то, можно поразмышлять о будущем без оглядки на настоящее!»). Цель сессии: команде предстоит направить свое внимание и творческую энергию на принципиально новые стратегические горизонты развития проекта вместо фокусировки на тактических проблемах. Риски: принятые решения могут оказаться весьма далекими от реальности и несовместимыми с текущей ситуацией.

3. «Через анализ сегодняшнего дня из настоящего в будущее». Здесь мы сознательно усложняем и удлиняем наш маршрут: 1 ) анализируем состояние на сегодняшний день $\rightarrow 2$ ) смотрим в желательное для нас будущее $\rightarrow 3$ ) принимаем решение. Показания к применению: команда уже имеет согласованное видение будущего своей организации, а стратегические цели обсуждаемого на сессии проекта разделяются всеми участниками. Однако у присутствующих все же остается опасение, что реальные оперативные действия будут отклоняться от стратегических ориентиров («Наши желания не всегда совпадают с нашими реальными возможностями!»). Цель сессии: соотнести актуальные тактические действия с миссией самой организации и со стратегией проекта в целом, чтобы иметь возможность своевременно вносить необходимые коррективы при выполнении ближайших задач. Риски: при концентрации внимания на болевых точках сегодняшнего дня мы рискуем нерационально растратить свою энергию и творческий потенциал на сиюминутные мелочи. В итоге, добравшись-таки до стратегического планирования, мы окажемся творчески истощены и ограничены рамками сегодняшних проблемных ситуаций. Данное обстоятельство, в свою очередь, наложит значительные ограничения как на сам процесс, так и на результат масштабного стратегического планирования. Предлагаемый маршрут обусловлен так называемым «реактивным мышлением», что предполагает подстройку действий под имеющиеся ресурсы, или, как принято 
говорить, «жизнь по средствам». На данном маршруте мы смотрим в будущее сквозь фильтр сиюминутных неурядиц и досадных недоразумений, теша себя иллюзией: справимся с отдельными недостатками - и желаемая цель будет достигнута сама собой.

\section{4. «Через видение будущего от будущего к настоящему».} Рекомендуется нами в качестве наиболее оптимального маршрута для сессии организационного развития.

Выбираем следующую принципиальную последовательность шагов: 1) смотрим в желаемое для нас будущее $\rightarrow 2$ ) смотрим на настоящее и $\rightarrow 3$ ) принимаем решение. Показания к применению: команда пока еще не имеет согласованного видения будущего, и стратегические цели обсуждаемого на сессии проекта разделяются далеко не всеми участниками. Цель сессии: разработать согласованную программу стратегического развития организации. Основная установка данного маршрута - соотносить намеченные стратегические ориентиры не столько с очевидными тактическими условиями и задачами, сколько с поиском скрытых потенциальных возможностей («Если их пока еще не нашли, то это не потому что их нет, а потому, что их плохо искали!»). Мы будем заниматься стратегическим планированием, имея перед глазами образ желаемого конечного результата и стараясь отыскать в сегодняшних условиях пока что скрытые потенциальные возможности для его достижения. И такое поведение уже в корне отличается от пассивной установки «подстроиться под имеющиеся очевидные ресурсы» и «жить по средствам». Напротив, получая мощный позитивный заряд энергии из будущего, мы переносим его в день сегодняшний, расширяя тем самым круг наших возможностей. Данный маршрут вполне соотносится с так называемым «проактивным мышлением», иными словами, с поиском скрытых возможностей для получения идеального конечного результата. Риски: под влиянием нахлынувших эмоций участники способны усомниться в собственных силах, как только им станет очевидна реальная пропасть между желаемым образом будущего и актуальным состоянием проекта. И, как следствие, команда может неоправданно занизить 92 
как собственные притязания, так и планку перспективного развития всей организации.

Технологической основой проведения сессии выступают методы групповой фасилитащии, применяемые для управления процессами внутригрупповой динамики и повышения эффективности взаимодействия людей в команде.

Meтоды групповой фасилитащчи представляют собой комплекс творческих и логических приемов для совместного принятия решений, в обсуждение которых максимально вовлечен каждый из участников. Использование фасилитационных методов способно раскрыть творческий потенциал как отдельных сотрудников, так и коллектива единомышленников в целом. Формат фасилитационной сессии уже сам по себе предполагает открытый диалог между участниками управленческой команды, на основе которого как раз и принимаются системные стратегические решения. Именно в этом и заключается качественное отличие фасилитационной сессии от традиционных совещаний, когда некое деловое предложение, единолично высказанное кем-то из авторитетных участников, тут же ставится на групповое голосование.

Какие же возможности предоставляет группе формат фасилитационной сессии? Во-первых, он реально повышает качество принимаемых решений; во-вторых, формирует ответственность каждого из участников в последующей реализации задуманного; в-третьих, ускоряет переход новаторских идей в практическую плоскость, в-четвертых, делает более эффективным взаимодействие между участниками группы (причем как в рамках самой сессии, так и за их пределами); в-пятых, повышает личностную удовлетворенность каждого от самого процесса и от конечного результата совместной работы; и, наконец, в-шестых, способствует саморазвитию участников [1].

Динамика групповых процессов находится под контролем так называемого фасилитатора - эксперта в области групповых процессов, владеющего целым арсеналом эффективных методов, а потому способного структурировать работу творческой группы как особой социальной системы. 
Фасилитатор создает условия, позволяющие группе:

- настроиться на творческий лад;

- работать в позитивной атмосфере;

- сформулировать смысл, иели и задачи повседневной работы вне рамок сессии;

- опредметить насущные личностные потребности в отношении организации, превратив их в конкретные мотивы созидательной деятельности, выполняемой с удовольствием;

- перейти к сплоченному взаимодействию для достижения целей сессии;

- настроиться на то, чтобы сльшиать и фиксировать буквально каждую уникальную мысль, высказываемую любым из участников;

- получить возможность генерировать максимальное количество идей;

- принимать на основе обсуждаемых идей конкретные решения;

- переводить решения в план реализации;

- направлять энергию конфликта и критики на поиск оптимальных решений как внутри группы, так и вне еe.

Здесь следует обратить особое внимание на то, что фасилитатор вовсе не должен выступать узкоспециилизированным экспертом в той профессиональной области, к которой непосредственно относятся принимаемые группой решения. Более того, его влияние на само содержание групповых решений, насколько парадоксальным бы это ни казалось, должно стремиться к минимуму (полностью исключить влияние фасилитатора, к сожалению, невозможно, так как выбранный им формат работы сам по себе непроизвольно оказывает влияние на содержание групповых решений). Фасилитатор призван лишь конструировать формат, создавая так называемую «емкость сессии», которую участники имеют возможность самостоятельно наполнить мыслями, оценками и выводами. Не погружаясь с головой в процесс генерации идей и предложений, фасилитатор лишь стимулирует ведомую группу соблюдать определенные «рамки эффективности» (например, по взаимной 
договоренности - хотя и с подачи фасилитатора - все решения группы могут формулироваться ее участниками исключительно в терминах результата, а не процесса).

Стоит фасилитатору проявить хотя бы малейшую симпатию в отношении чьего-либо мнения, как тут же возникает риск того, что он осознанно или бессознательно перейдет от своей исходной роли наблюдателя к роли организационного консультанта. Это, в свою очередь, способно отрицательно повлиять на эффективность групповой работы в целом, так как фасилитатор из усилителя групповой динамики превращается в ее ограничителя (говоря научно, ингибитора). Вероятность такого перевоплощения уже на самых ранних стадиях должна отчетливо осознаваться фасилитатором, и ему следует делать все, чтобы избежать подобного развития событий. Что же касается самих участников группы, то они изначально должны быть уверены в том, что фасилитатор лоялен ко всем без исключения мнениям. Более того, как полагают некоторые ведущие западные бизнес-тренеры, кратковременные переходы фасилитатора в роль эксперта по обсуждаемому вопросу, которые иногда оказываются необходимыми, должны особо озвучиваться им самим [2].

Возникает вполне закономерный вопрос: может ли сам владелец бизнеса или кто-либо из лидирующих руководителей компании выступать в роли фасилитатора?

Скептики ответили бы на этот вопрос отрицательно. И на то есть весомые причины. В гипотетическом случае, когда сам руководитель играет роль ведущего сессии, вероятны два весьма неэффективных (как для дальнейшего развития бизнеса в целом, так и для достижения локальной целей фасилитационной встречи) сценария:

1) руководитель, играющий роль фасилитатора, полностью устраняется от создания идей в ходе сессии и обсуждения принимаемых решений, хотя потенциально способен внести важный, а подчас и решающий вклад в содержание результатов встречи; 
2) совмещая две роли - «беспристрастного» и «лояльного» ведущего и «одержимого» генератора идей одновременно, такой руководитель неизбежно теряет контроль за следованием маршруту сессии и выполнением участниками правил взаимодействия.

И тем не менее мы вполне допускаем успешное исполнение руководителем роли ведущего фасилитационной сессии. Однако, для того чтобы озвученные выше негативные сценарии не стали реальностью, настоятельно рекомендуем менеджеру-фасилитатору соблюдение следующих непременных условий:

1. Принять на себя установку отступить на второй план, передав инициативу своим подчиненным и предоставив им максимальную свободу в предложении идей по развитию бизнеса.

2. Открывая фасилитационную сессию, сообщить группе о том, что перевоплощаетесь в роль ведущего. Руководитель отвечает исключительно за формат и соблюдение правил групповой работы. Лишь в случае крайней необходимости и после специального предупреждения вы сможете открыто высказывать свое личное мнение, на краткий миг перейдя из роли фасилитатора в роль руководителя.

3. Высказывать свое собственное мнение лишь тогда, когда оно не было до вас высказано кем-либо из участников, и делая это в самую последнюю очередь, после того, как высказались все остальные.

4. Давать возможность высказать мнение всем без исключения участникам сессии безотносительно к вашему личностному отношению к отдельным персонам.

5. Если вы убеждены, что участники в любом случае будут воспринимать вас скорее как предвзятого и требовательного руководителя, нежели как лояльного модератора сессии (что неизбежно будет сковывать их творческую активность и блокировать искренность высказываний), лучше изначально отказаться от роли фасилитатора, передав ее комулибо другому. 
6. Озвучивая промежуточные и конечные итоги встречи, ориентироваться на складывающееся групповое мнение, а не ваши личные симпатии и предпочтения.

7. Касаясь фазы принятия окончательных организационных решений, переводящих найденные идеи в реальную плоскость, лучше было бы перенести ее на следующую встречу, уже тогда уступив роль ведущего профессиональному фасилитатору и перевоплотившись на данной стадии групповой работы в роль равноправного участника.

Теперь несколько слов о факторах, определяющих успех сессии организационного развития, позволяющие дать основные рекомендации фасилитатору:

1. Сформируйте понимание стратегических решений на всех уровнях компании, начиная с топ-менеджера и заканчивая рядовым сотрудником. После того как высшие руководители в ходе сессии сформулируют стратегию развития компании в неких абстрактных понятиях, очень важно провести аналогичную сессию с линейныли руководителями, для того чтобы развернуть абстракцию до уровня конкретики. В этом случае линейные руководители оказываются полноправными соавторами принимаемой стратегии, а результатом сессии становится программа конкретных действий, детализированная измеримыми показателями, сроками и ответственными исполнителями.

2. Непременно включите первое лицо компании как в сам процесс разработки сценария (на этапе подготовки), так и в состав непосредственных участников сессии (на этапе проведения). В этом случае еще в период подготовки фасилитатору удастся выяснить, какой же практический смысл топ-руководитель вкладывает в проведении сессии и какой именно результат желает от нее получить. Далее, сам факт присутствия на сессии первого лица компании существенно повышает статус задуманного мероприятия. А это, в свою очередь, дает понять остальным участникам, что решения, которые предстоит принять по окончании сессии, априори будут обладать практической ценностью и получат 
шанс увидеть свет. И напротив, если в глазах главы компании сессия организационного развития представляет собой лишь очередное формальное совещание, даже самые талантливые и креативные решения будут иметь весьма иллюзорную возможность для своей практической реализации.

\section{3. Сфокусируйте внимание всех без исключения участни-} ков на основной цели сессии. Выполнение данного условия означает, что по завершении каждого из промежуточных этапов сессии фасилитатору необходимо давать участникам обратную связь, показывая, насколько эффективно, с его точки зрения, группа работает для достижения запланированного конечного результата.

\section{4. Стимулируйте эмоциональное вовлечение участников} в процесс сессии. И здесь фасилитатору предстоит создать условия, при которых участники смогут открыто и искренне выражать свое эмоциональное отношение к принимаемым решениям. Действительно, в случае, когда у непосредственного исполнителя отсутствует эмоциональное согласие с тем или иным групповым решением, он, скорее всего, станет неосознанно препятствовать его практической реализации, и, напротив, на основе эмоционального согласия с решением у участника появляется «прочувствованная» готовность следовать ему на практике. Вместе с тем случаи открытого эмоционального несогласия с принимаемым решением свидетельствуют о том, что поставленная задача далеко не безразлична человеку. Подобное несогласие следует воспринимать как источник энергии, которую фасилитатору предстоит направить в конструктивное русло: нужно предоставить участникам, придерживающимся противоположных взглядов, максимально комфортную возможность предлагать альтернативные решения. В этом случае весьма велика вероятность, что какое-либо из таких решений окажется гораздо эффективнее ранее сформированного ${ }^{1}$.

\footnotetext{
${ }^{1} \mathrm{O}$ технологиях перевода эмоционального несогласия в конструктивное русло см.: Петров A. Ю., Петров Е. А. Генерация прорывных идей в бизнесе. Гл 3. 


\section{5. Стимулируйте максимальную творческую активность}

участников. Для этого мы предлагаем воспользоваться следующими возможными способами:

- Введите общий сюжетный контекст, красной нитью проходящий через все этапы сессии и логически связывающий их между собой. Таким контекстом, к примеру, могут выступать конкретные сюжетные условия деловой игры, а также исходное распределение ролей между участниками.

- Четко и доступно объясните участникам цели каждого из промежуточных этапов групповой работы, продемонстрировав их органическую связь с конечной целью сессии в целом и задав жесткие временные рамки для каждого из промежуточных обсуждений.

- Чередуйте формы групповой активности внутри этапов: в среднем один раз в 10 минут рекомендуется менять одну форму на другую.

6. Дайте участникам возможность посмотреть на задачу c различных точек зрения. Поставьте участников сессии на место их клиента, партнера или конкурента. Подобные смены ролей позволяют значительно расширить область поиска решений, а также сделать таковые более эффективными в практическом плане.

\section{7. Иницииуйте создание эффективной системы исполне-} ния принятых решений. Действительно, организационные изменения станут возможными лишь тогда, когда сам сценарий фасилитационной сессии будет изначально предполагать выработку программы исполнения принятых на сессии решений.

Так называемая система исполнения может быть реализована в виде четырех мини-сессий, следующих за первой (базовой) сессией организационного развития с интервалами в три месяца. На этих мероприятиях отслеживается динамика реализации стратегии, принятой изначально. Как показывает практика, при отсутствии подобных мини-сессий команде весьма сложно придерживаться стратегического решения на фоне ежедневной рутины. 
Руководители также должны быть готовы и к тому, что эффект от предложенных по итогам сессии организационных изменений проявится далеко не сразу. В качестве аналогии представим водопроводный кран, к которому присоединен длинный резиновый шланг. Если повернуть кран, вода потечет из шланга не сразу. Даже если значительно увеличить напор, мы не получим мгновенного результата. В результате у нас может сложиться впечатление, что манипуляции с вентилем не дают ни малейшей отдачи. Однако все сомнения через некоторое время исчезнут, как только из шланга хлынет долгожданный поток воды. Аналогичная реакция на происходящее может иметь место и у менеджеров на самом начальном этапе запуска организационных изменений, когда расходуются весьма значительные материальные и человеческие ресурсы, а отдача со стороны самой организационной системы наблюдается минимальная.

Сам процесс фасилитации изначально сталкивается с множеством препятствий, не позволяющих групповому потенциалу раскрыться в полной мере.

Выделенные Б. Бункером и Б. Албаном так называемые дилеммы фасилитащии [3] мы дополнили бы и другими возможными ответными конструктивными действиями со стороны фасилитатора.

Дилемма голоса - вероятность того, что ценный опыт коголибо из участников сессии может быть так и не усльшан. Как показывает наша практика тренерской работы, кто-то из участников в силу вполне естественного предположения, что его игнорируют, повторяет одну и ту же мысль раз за разом, настойчиво перебивая коллег. В этом случае фасилитатору следует вводить и непрерывно поддерживать правило открытости: каждый присутствующий свободно и без каких-либо опасений высказывает свое мнение по обсуждаемым вопросам. Фасилитатор при этом обеспечивает фиксацию буквально каждого мнения, озвученного участниками. Мнения фиксируются на большом листе крупными печатными буквами так, чтобы каждый участник мог видеть их в ходе дискуссии. 
Дилемма структуры. В том случае, когда групповая работа структурируется фасилитатором в минимальной степени, участникам группы процесс кажется хаотичным и вышедшим из-под контроля. И, напротив, в случае, когда групповая работа структурирована сверх меры, участники ощущают некоторую искусственность формата, более того, у них невольно возникает опасение по поводу манипуляции и контроля над их поведением со стороны фасилитатора. Именно поэтому фасилитатору рекомендуется чередовать между собой структурированные и малоструктурированные форматы групповой работы: четкие инструкции в начале каждого из этапов сочетаются с полной свободой действий группы в процессе работы по выполнению задания.

Дилемма эгоцентризма. Участники группы склонны воспринимать свою точку зрения как единственно правильную и потому не уделять должного внимания альтернативным мнениям. В конечном итоге эгоцентризм участников может существенно снизить качество групповых решений. В ответ на подобные опасения фасилитатор вводит и поддерживает следующие правила групповой работы:

- «Говорим по одному»: право голоса предоставляется тому, кто поднял руку, причем в порядке очереди, никоим образом не зависящей от реального должностного статуса участника. Когда кто-то говорит, все остальные слушают!

- Правило лаконичности: здесь вполне возможен так называемый режим «хокку» - при необходимости следует ограничить продолжсительность высказываний до минуты и жестко контролировать регламент, используя секундомер. Кроме того, фасилитатор оставляет за собой право по своему усмотрению прервать чей-либо монолог и передать слово другому. Участники не имеют права повторять мысли, уже высказанные коллегами. Докладчики, презентующие результаты работы своей группы на очередном этапе сессии, говорят только об итогах обсуждения, а не воспроизводят весь ход общения участников. 
- Правило конструктивности критики: обсуждается лишь сам метод решения, но ни в коем случае не личность его автора; высказав критическое замечание, оппонент обязательно озвучивает следом собственный вариант решения, что существенно снижает риск перехода дискуссии в плоскость межличностного конфликта.

",Я“ не равно „мы“", использование так называемых «я-высказываний»: следует исключить выражения типа «все так считают», «как правило, все», «существует распространенное мнение», «общая точка зрения» и т. п.; лучше использовать фразы типа «по моему мнению», «я предполагаю», «на мой взгляд» и т. п.

Дилемма целесообразности (была выделена нами на основе реального практического опыта проведения сессий организационного развития). Мы ответственно заявляем, что даже при успешном решении всех изложенных выше дилемм группа тем не менее может так и не достичь поставленной сессией цели, так как:

- не отслеживает продвижения к итоговой цели через промежуточные этапы;

- фокусируется на прошлом вместо планирования будущего;

- обсуждает то, на что не в состоянии повлиять;

- уделяет бо́льшее внимание потребностям локальных подразделений, нежели потребностям всей компании в целом.

В связи с этим фасилитатор вводит и поддерживает следующие правила групповой работы.

1) «Обсуждаем только то, что непосредственно относится к целям и задачам сессии».

2) «После каждого этапа групповой работы фиксируем полученный результат и его связь с конечной целью».

3) «Ищем возможности в будущем, а не причины в прошлом», иными словами, вместо поиска причин проблемы, участники говорят о том, что именно они хотят увидеть вместо нее в будущем.

4) «Обсуждаем только то, на что мы способны повлиять»: участники фокусируют внимание на зоне своего непосредственного контроля и ищут возможности ее расширения. 
5) «В процессе принятии решений исходим из потребностей и ценностей компании в целом, а не ее отдельных частей».

Итак, сессия организационного развития, в отличие от традиционных и ситуативных бизнес-тренингов, нацелена исключительно на стратегическую перспективу. Этим объясняется ее принципиально иной масштаб как с количественной, так и с качественной точек зрения. Фасилитационный формат максимально активизирует творческий потенциал участников команды, которая охотно идет на риск и берет на себя ответственность за будущее своей организации. Сессия организационного развития как наиболее прогрессивная форма аккумуляции креативных усилий сотрудников закладывает основу для потенциального прорыва и веру в успех бизнеса.

\section{Список литературы}

1. Schwarz R. The Skilled Facilitator Approach / R. Schwarz // The IAF Handbook of Group Facilitation ; ed. by S. Schuman. San Francisco: JosseyBass, 2005. P. 21-34.

2. Jenkins J. C. Operational Dimensions of the Profession of Facilitation / J. C. Jenkins // The IAF Handbook of Group Facilitation; ed. By S. Schuman. San Francisco: Jossey-Bass, 2005. P. 473-494.

3. Bunker B. B. Large Group Interventions: Engaging the Whole System for RapidChange / B. B. Bunker, B. T. Alban. SanFrancisco: Jossey-Bass, 1997. 272 p.

\section{§ 2. Сохранение лояльности клиентов в ресторанном бизнесе компании «Юниверфуд» \\ в контексте развивающегося кризиса потребительской активности 2014-2015 гг.}

В параграфе рассматриваются проблемы предприятия ресторанного бизнеса связанные с лояльностью клиентов. Эмпирической базой исследования стал анализ анкетирования потребителей прошедший в предпраздничный и постпраздничный новогодний период 2014-2015 г. в компании «Юниверфуд». Компания 
«Юниверфуд» основана в 2001 г, основным видом деятельности является ресторанный бизнес. География бизнеса распространена в 21 городе Российской Федерации, имеет разветвленную филиальную сеть присутствия в 52 торговых центрах, 140 точек продаж. Формат кафе и баров специально спроектирован под фудкорты в торгово-развлекательных центрах.

Основной проблемой компании, начиная с осени 2014 г., стали высокие арендные ставки в связи с колебанием курса валют. Большинство арендных договоров были оформлены в иностранной валюте. Около 30 \% арендодателей пошли на встречу компании и заморозили стоимость аренды, введя «внутренний курс» валюты. Несмотря на усилия, компании в переговорах по арендным ставкам пришлось идти на сокращение издержек, и были закрыты 30 низкорентабельные точек продаж в разных городах. В контексте этих событий компания решила акцентировать свои маркетинговые усилия на удержании клиентов путем повышения лояльности. Формат free flow позволяет существенно снизить издержки предприятия на рекламу и привлечение клиентов. На сегодняшний день для организации ресторана быстрого обслуживания наиболее перспективным направлением является формат free flow («свободное перемещение»). Отличительными характеристиками этого формата являются наличие открытой кухни, приготовление блюд на глазах у посетителей, принцип самообслуживания и широкий выбор предлагаемых блюд. Приготовление блюд в заведениях формата free flow превращено в захватывающее кулинарное шоу, театрализованное представление. Это спектакль, посвященный приготовлению и вкушению еды. Формат free flow отличает максимально демократичная система работы с потребителем. В традиционном free flow отсутствуют раздачи, вынуждающие гостя выстоять очередь и пройти всю ассортиментную линейку. Благодаря food stations (отдельным «островкам» с блюдами разных кухонь и стоимостью) даже при большом количестве посетителей удается избежать длинной очереди. Основные «островки» - это овощной, кофейный, пивной, линия горячих блюд и линия самообслуживания. Плюс в том, что заказ не надо 104 
ждать. Также чтобы избежать очередей и сделать процедуру заказа более удобной, в некоторых ресторанах предусмотрено несколько линий раздачи [1].

Основной задачей компании остается удержание клиентов высоким качеством обслуживания и блюд. Лояльность в большинстве случаев ассоциируют с повторной покупкой [2].

Потребитель следует схеме повторной покупки, потому что именно эта торговая марка хорошо удовлетворяет его потребности или потому что у него формируется личная приверженность марке. По мнению J. Liesse [3] и S. Schlueter [4], «приверженность марке также может быть следствием ее эмоционального влияния на потребителя или ее влияния на самооценку потребителя».

\section{Кейс 1: American Hot Pizza}

Исследование проводилось в виде анонимного анкетирования с пятью контрольными вопросами и необязательной обратной связью в виде контактной информации об анкетируемом. Всего в анкетировании приняло участие 57 человек без гендерного различия, возрастной категории и без актуализации платежеспособности. В результате исследования были выявлены детские ответы (про учебу, школу, игрушки, компьютерные игры). Заполнение ребенком анкеты говорит о семейном времяпровождении в заведении, предоставления детям самостоятельности, следовательно, предоставления права самостоятельного выбора в меню, поэтому следует усилить влияние в этом плане на детей через введение в меню детской карты или детского уголка для формирования будущих постоянных клиентов, которые в дальнейшем тоже приведут своих детей, тем самым формируя постоянную базу клиентов.

В результате анализа были получены следующие данные. Постоянными клиентами являются более 60 \% анкетируемых, 40 положительных ответов из 57. Из положительных отзывов о деятельности предприятия стоит отметить, что особенно нравится основная продукция (еда) - 48 ответов, это подавляющее большинство ответов. После этого следуют положительные отзывы об обслуживании и ассортименте - 36 из 57, что составляет более 50 \% клиентов, которые уделяют этому особе внимание. 
Это говорит о хорошей работе действующего персона, его подготовке и лояльном отношении к предприятию. Абсолютную удовлетворенность от предприятия ответом «Понравилось» показали все 17 человек. Понравилась атмосфера предприятии и в целом положительный образ - 14 ответов. Положительные отзывы о работе персонала оставили 4 человека, но это может говорить только об общей интегрированности персонал в корпоративную модель работы предприятия, потому что предыдущие положительные ответы были бы невозможны без положительной работы персонала. Общее количество ответов с отрицательными отзывами на вопрос «Что вам не понравилось?» составило 8, это чуть более $10 \%$ и носит рекомендательный характер к улучшению работы. Их можно структурировать следующим образом. Претензии к обслуживанию и времени - 4 ответа, внутреннему обустройству - 2 ответа, ассортименту - 2 ответа.

Структура новогодних пожеланий заведению показала следующие результаты: желают роста компании, расширения филиальной сети, географии присутствия и в целом позитивные пожелания 47 ответов. Из этих ответов стоит обратить на такое пожелание, как география присутствия, это говорит о желании людей иметь больше возможностей посещать заведения. Увеличение клиентской базы - 35 пожеланий. Нужно выделить особые пожелания клиентов, которые могут привести к усилению позиций компании и увеличению конкурентоспособности: добавьте еду в коробочках, порции побольше, заведите бонусную (скидочную) карту giftoman, снижение цены, скидки для студентов, основные просьбы направлены на ценовую политику предприятия, что можно трактовать как просьба о модернизации или внедрении дисконтной системы.

Контакты для обратной связи оставили 31 человек, это более $50 \%$ респондентов. Значит, они готовы получать информационную и рекламную продукцию компании, тем самым и предыдущими ответами клиенты показывают высокую лояльность к предприятию.

Из анкеты были выделены реализуемые желания клиентов, они носят низкобюджетный характер и при должной рекламной 106 
кампании и освещении в СМИ вызовут положительный резонанс и привлечение внимания к предприятию: мешок конфет, любой подарок, сыр пармезан, духи, мягкая игрушка, зверошапка, вкусный молочный коктейль, круг пиццы «Американ Хот», машина (игрушка).

\section{Кейс 2: Блинофф}

Исследование проводилось в виде анонимного анкетирования с пятью контрольными вопросами и необязательной обратной связью в виде контактной информации об анкетируемом. Всего в анкетировании приняло участие 53 человека без гендерного различия, возрастной категории и без актуализации платежеспособности. В результате исследования были выявлены характерные ответы студентов (про учебу, сессию и т. п.). Это говорит о том, что традиционная русская кухня пользуется популярностью у студенчества и указывает на демократическую ценовую политику, принятую на предприятии.

В результате анализа были получены следующие данные. Постоянными клиентами являются более 70 \% анкетируемых, 40 положительных ответов из 53. Из положительных отзывов о деятельности предприятия стоит отметить, что особенно нравится основная продукция (еда) - 28 ответов, это подавляющее большинство ответов. После этого следуют положительные отзывы об атмосфере предприятии и в целом положительном образе - 12 ответов. Абсолютную удовлетворенность от предприятия ответом «Понравилось» показали все 9 человек. Обслуживанию и ассортименту уделили внимание 5 человек. В целом положительные ответы говорят о том, что постоянных клиентов у предприятия составляет большинство, их привлекает основная продукция компании и созданная атмосфера доброжелательности, а также демократические цены. Это говорит о верной политике избранной для работы компании, но стоит обратить внимание на работу персонала, так как отзывов о персонале практически нет, а персонал, в свою очередь, является лицом и главным продажным активом. 
Общее количество ответов с отрицательными отзывами на вопрос «Что вам не понравилось?» составило 12, это около 20 \%, и основная претензия к продукции компании. Их можно структурировать следующим образом. Претензии к обслуживанию и времени - 1 ответ, это вполне может быть погрешность и настроение клиента. К внутреннему обустройству — 4 ответа, основная претензия к температурному режиму, очень жарко и душно. Основные претензии относятся к продукции и ассортименту - 6 ответов, на это стоит обратить пристальное внимание, так как это является основной частью доходов предприятия и может влиять на его конкурентоспособность.

Структура новогодних пожеланий заведению показала следующие результаты: желают роста компании, расширения филиальной сети, географии присутствия и в целом позитивные пожелания 25 ответов. Из этих ответов стоит обратить на такое пожелание, как география присутствия в микрорайоне Академический. Увеличение клиентской базы - 11 пожеланий. Нужно выделить особые пожелания клиентов, которые могут привести к усилению позиций компании и увеличению конкурентоспособности: основная просьба - установить кондиционер - 4 пожелания, расширение ассортимент (новые начинки для блинов), травяные чаи.

Контакты для обратной связи оставили 38 человек, это более $60 \%$ респондентов. Значит, они готовы получать информационную и рекламную продукцию компании, тем самым и предыдущими ответами клиенты показывают высокую лояльность к предприятию.

Из анкеты были выделены реализуемые желания клиентов, они носят низкобюджетный характер и при должной рекламной кампании и освещении в СМИ вызовут положительный резонанс и привлечение внимания к предприятию: попробовать блинчики со всеми начинками, путешествие, снегокат, бочку с блинами, новые туфли.

\section{Кейс 3: Parasole}

Исследование проводилось в виде анонимного анкетирования с пятью контрольными вопросами и необязательной обратной 108 
связью в виде контактной информации об анкетируемом. Всего в анкетировании приняло участие 67 человек без гендерного различия, возрастной категории и без актуализации платежеспособности. В результате исследования были выявлены ответы, относящиеся к категории потребителей экономически активного населения и входящие в бизнес-среду, это ответы, связанные с курсом иностранных валют, а также клиенты, входящие в категорию студентов.

В результате анализа были получены следующие данные. Постоянными клиентами являются около 70 \% анкетируемых, 46 положительных ответов из 67. Большое количество анкетируемых, из которых 21 ответ говорит о новым опыте в рестораном Parasole и интересе, проявляемом к итальянской кухне. Из положительных отзывов о деятельности предприятия стоит отметить, что особенно нравится основная продукция (еда) - 29 ответов, это подавляющее большинство ответов. После этого следуют положительные отзывы об обслуживании и ассортименте - 20 ответов. Особое внимание уделяют атмосфере, созданной на предприятии, и положительном образе - 19 ответов. Это говорит о верной концепции предприятия, хорошей работе действующего персона, его подготовке. Абсолютную удовлетворенность от предприятия ответом «Понравилось» показали все 6 человек. Положительные отзывы о работе персонала оставили 11 человек, вплоть до восторженных отзывов. Это говорит об отличной организации и подготовке персонала. Общее количество ответов с отрицательными отзывами на вопрос «Что вам не понравилось?» составило 15, это чуть более 20 \% и носит рекомендательный характер к улучшению работы. Их можно структурировать следующим образом. Претензии к обслуживанию и времени - 2 ответа, опять же подтверждается отличная организация и работа персонала; внутреннему обустройству - 7 ответов, большие претензии к громкой музыке, следует ввести стандарт звукового фона; к ассортименту - 6 ответов, просят увеличить ассортимент соусов и ввести в меню грибной суп. 
Структура новогодних пожеланий заведению показала следующие результаты: желают роста компании и в целом позитивные пожелания - 40 ответов. Увеличение клиентской базы - 14 пожеланий. Нужно выделить особые пожелания клиентов, которые могут привести к усилению позиций компании и увеличению конкурентоспособности: просьба об организации акций и увеличении ассорти итальянских колбас и сыров. Эти пожелания можно трактовать как запрос клиентов на программу лояльности. В целом по анализу анкет можно сказать, что у предприятия выделены четкие приоритеты, хорошо ориентированность на клиентов, верная ценовая политика и отличная организация работы персонала.

Контакты для обратной связи оставили 51 человек, это великолепный результат. Значит, они готовы получать информационную и рекламную продукцию компании, тем самым и предыдущими ответами клиенты показывают высокую лояльность к предприятию.

Из анкеты были выделены реализуемые желания клиентов, они носят низкобюджетный характер и при должной рекламной кампании и освещении в СМИ вызовут положительный резонанс и привлечение внимания к предприятию: мешок карамели, завести собаку, сертификат в салон красоты Владимира Мотчаного, ноутбук, бесплатный ужин в Parasole, уехать туда, где тепло (баня?!), вкусный итальянский десерт, наушники Beats.

\section{Кейс 4: Cherry Berry}

Исследование проводилось в виде анонимного анкетирования с пятью контрольными вопросами и необязательной обратной связью в виде контактной информации об анкетируемом. Всего в анкетировании приняло участие 53 человека без гендерного различия, возрастной категории и без актуализации платежеспособности. В результате исследования не были выявлены ответы, способные указать на особые характеристики отвечающих, это означает, что предприятия пользуется спросом у всех категорий платежеспособного населения.

В результате анализа были получены следующие данные. Постоянными клиентами являются около более 50 \% анкетируе- 
мых, 34 положительных ответа из 53. Из положительных отзывов о деятельности предприятия стоит отметить, что особенно нравится основная продукция (еда) - 42 ответа, это подавляющее большинство ответов. После этого следуют положительные отзывы об обслуживании и ассортименте - 29 ответов. Абсолютную удовлетворенность от предприятия ответом «Понравилось» показали все 11 человек, очень высокий показатель. Обратили внимание на атмосферу заведения 6 человек. Положительные отзывы о работе персонала оставили 3 человека. Клиенты предприятия являются постоянными, и их привлекает основная продукция и ценовая политика предприятия. Общее количество ответов с отрицательными отзывами на вопрос «Что вам не понравилось?» составило 6, и, скорее всего, не было бы ни одного, если бы не сломалось оборудование. Это говорит о хорошей работе персонала и созданной атмосфере. Их можно структурировать следующим образом. Претензии к обслуживанию и времени не было вообще; внутреннему обустройству - 5 ответов, это было вызвано поломкой оборудования; к ассортименту — 1 ответ, просят включить в ассортимент простое мороженое.

Структура новогодних пожеланий заведению показала следующие результаты: желают роста компании и в целом позитивные пожелания - 56 ответов, это говорит о высоком уровне удовлетворенности и лояльности клиентов к предприятию. Увеличение клиентской базы - 19 пожеланий. Нужно выделить особые пожелания клиентов, которые могут привести к усилению позиций компании и увеличению конкурентоспособности: увеличить ассортимент топингов, снизить цены, увеличить фруктовый ассортимент, ввести вафельные стаканчики и организовать акции.

Контакты для обратной связи оставили 38 человек, это более $50 \%$. Значит, они готовы получать информационную и рекламную продукцию компании, тем самым и предыдущими ответами клиенты показывают высокую лояльность к предприятию.

Из анкеты были выделены реализуемые желания клиентов, они носят низкобюджетный характер и при должной рекламной кампании и освещении в СМИ вызовут положительный резонанс 
и привлечение внимания к предприятию: путешествие, паровозик, куклу Эльзу, которая поет, часы, корзина вкуснятины, килограмм йогурта из Cherry Berry, йогурт с кедровыми орешками, шоколадка.

\section{Кейс 5: Juice-master}

Исследование проводилось в виде анонимного анкетирования с пятью контрольными вопросами и необязательной обратной связью в виде контактной информации об анкетируемом. Всего в анкетировании приняло участие 60 человек без гендерного различия, возрастной категории и без актуализации платежеспособности. В результате исследования не были выявлены ответы, способные указать на особые характеристики отвечающих, это означает, что предприятия пользуется спросом у все категорий платежеспособного населения.

В результате анализа были получены следующие данные. Постоянными клиентами являются около почти 80 \% анкетируемых, 51 положительных ответов из 60. Из положительных отзывов о деятельности предприятия стоит отметить, что особенно нравится основная продукция (еда) - 31 ответ и обслуживания и ассортимента - 34 ответа. Это говорит о высокой степени организации и верном выборе формата заведения. Абсолютную удовлетворенность от предприятия ответом «Понравилось» показали все 11 человек, очень высокий показатель. Обратили внимание на атмосферу заведения 12 человек. Положительные отзывы о работе персонала оставили 3 человека. Общее количество ответов с отрицательными отзывами на вопрос «Что вам не понравилось?» составило 3, 2 из них было к долгому ожиданию заказа, скорее всего, это связано с ажиотажным спросом и высокой нагрузкой в праздничный период. Это говорит о хорошей работе персонала и созданной атмосфере. Их можно структурировать следующим образом.

Структура новогодних пожеланий заведению показала следующие результаты: желают роста компании и в целом позитивные пожелания - 60 ответов, это 100 \%, и это говорит о высоком уровне удовлетворенности и лояльности клиентов к предприятию. Увеличение клиентской базы - 5 пожеланий. Особые пожеланий клиентов, которые могли бы привести к усилению позиций компании 
и увеличению конкурентоспособности не было. Это говорит о правильной клиентоориентированной политике предприятия.

Контакты для обратной связи оставили 49 человек, это более 50 \%. Значит, они готовы получать информационную и рекламную продукцию компании, тем самым и предыдущими ответами клиенты показывают высокую лояльность к предприятию.

Из анкеты были выделены реализуемые желания клиентов, они носят низкобюджетный характер и при должной рекламной кампании и освещении в СМИ вызовут положительный резонанс и привлечение внимания к предприятию: сок, мандарин, клюкву в сахарной пудре.

\section{Кейс 6: Das Колбаs}

Исследование проводилось в виде анонимного анкетирования с пятью контрольными вопросами и необязательной обратной связью в виде контактной информации об анкетируемом. Всего в анкетировании приняло участие 114 человек без гендерного различия, возрастной категории и без актуализации платежеспособности. В результате исследования были выявлены ответы, относящиеся к категории потребителей экономически активного населения и входящие в бизнес-среду и привыкшие к высокому уровню жизни, это ответы, связанные с курсом иностранных валют, дорогостоящих вещей и предметов роскоши.

В результате анализа были получены следующие данные. Постоянными клиентами являются около 70 \% анкетируемых, 77 положительных ответов из 114. Из положительных отзывов о деятельности предприятия в первую очередь стоит отметить, что особенно нравится основная продукция (еда) - 79 ответов, это подавляющее большинство ответов. После этого следуют положительные отзывы об обслуживании и ассортименте 65 ответов. Особое внимание уделяют атмосфере, созданной на предприятии, и положительном образе - 30 ответов. Это говорит о верной концепции предприятия, хорошей работе действующего персона, его подготовке. Стоит обратить внимание на положительные отзывы о работе персонала, неоднократно были указаны конкретное персоналии, считаем возможным поощрения этого персонала в связи 
результатами анкетирования, выявленным высокого уровня лояльности и для повышения корпоративного духа компании. Абсолютную удовлетворенность от предприятия ответом «Понравилось» показали все 18 человек. Положительные отзывы о работе персонала оставили 4 человека, вплоть до восторженных отзывов. Это говорит об отличной организации и подготовке персонала. Общее количество ответов с отрицательными отзывами на вопрос «Что вам не понравилось?» составило 51, что приближается к отметке в $50 \%$, и не всегда носит рекомендательный характер к улучшению работы. В этом случае есть большое поля для усиления корпоративной работы. Их можно структурировать следующим образом. Претензии к обслуживанию и времени - 7 ответов, опять же подтверждается отличная организация и работа персонала; внутреннему обустройству — 23 ответа, большие претензии к громкой музыке и ожиданию заказа: следует ввести стандарт звукового фона; к ассортименту - 21 ответ. Основная претензия к отсутствию темного пива и маленьким порциям, скорее всего, это связано с ажиотажным спросом в праздничное время, поэтому рекомендуется увеличивать складские запасы на время праздников, так как логистические и предприятия поставщики не всегда готовы пойти навстречу и осуществлять отгрузки в праздничные дни.

Структура новогодних пожеланий заведению показала следующие результаты: желают роста компании и увеличения географического присутствия в г. Екатеринбурге, в целом позитивные пожелания - 114 ответов. Увеличение клиентской базы 56 пожеланий. Нужно выделить особые пожелания клиентов, которые могут привести к усилению позиций компании и увеличению конкурентоспособности: быстрее готовить еду, Wi-Fi, увеличить ассортимент и запасы пива, открыть дополнительные рестораны на Сортировке и Уралмаше, разнообразить меню, добавить мягкие подушки на скамейки, ввести в продажу квас «Вятский». В целом по анализу анкет можно сказать, что у предприятия выделены четкие приоритеты, хорошо ориентированность на клиентов, верная ценовая политика и отличная организация работы персонала. 
Контакты для обратной связи оставили 76 человек. Значит, они готовы получать информационную и рекламную продукцию компании, тем самым и предыдущими ответами клиенты показывают высокую лояльность к предприятию.

Из анкеты были выделены реализуемые желания клиентов, они носят низкобюджетный характер и при должной рекламной кампании и освещении в СМИ вызовут положительный резонанс и привлечение внимания к предприятию: книги, шоколадку, клетку для хомячка, плюшевого осьминога, карту постоянного клиента, шапочку с бамбончиком, шашки.

\section{Кейс 7: Дюжина}

Исследование проводилось в виде анонимного анкетирования с пятью контрольными вопросами и необязательной обратной связью в виде контактной информации об анкетируемом. Всего в анкетировании приняло участие 109 человек без гендерного различия, возрастной категории и без актуализации платежеспособности. В результате исследования были выявлены ответы, относящиеся к категории потребителей экономически активного населения и входящие в бизнес-среду и привыкшие к высокому уровню жизни, это ответы, связанные с курсом иностранных валют, дорогостоящих вещей и предметов роскоши. Также имело место множество ответов с указанием на школьную и студенческую социальную принадлежность, а значит, семейное посещение ресторана.

В результате анализа были получены следующие данные. Постоянными клиентами являются около 90 \% анкетируемых, 93 положительных ответов из 109. Из положительных отзывов о деятельности предприятия в первую очередь стоит отметить, что особенно нравится основная продукция (еда) - 100 \% ответов, это самый лучший показатель по всей сети компании. После этого следуют положительные отзывы об обслуживании и ассортименте 64 ответа. Особое внимание уделяют атмосфере, созданной на предприятии и положительном образе, - 38 ответов. Это говорит о верной концепции предприятия, хорошей работе действующего персона, его подготовке. Абсолютную удовлетворенность 
от предприятия ответом «Понравилось» показали все 32 человека. Положительные отзывы о работе персонала оставили 12 человек, вплоть до восторженных отзывов. Стоит обратить внимание на положительные отзывы о работе персонала, неоднократно были указаны конкретные персоналии, считаем возможным поощрения этого персонала в связи результатами анкетирования, выявленным высоким уровнем лояльности, и для повышения корпоративного духа компании. Это говорит об отличной организации и подготовке персонала. Общее количество ответов с отрицательными отзывами на вопрос «Что вам не понравилось?» составило 51, что приближается к отметке в 50 \%, и не всегда носит рекомендательный характер к улучшению работы. В этом случае есть большое поле для усиления корпоративной работы. Их можно структурировать следующим образом. Претензии к обслуживанию и времени - 4 ответа, опять же подтверждается отличная организация и работа персонала; внутреннему обустройству — 24 ответа, большие претензии к температурному режиму и просьбой кондиционирования воздуха и отсутствию туалета; к ассортименту - 2 ответа, отсутствие светлого пива.

Структура новогодних пожеланий заведению показала следующие результаты: желают роста компании и уверенно сохранения своих позиций на занимаемом рынке в г. Екатеринбурге, в целом позитивные пожелания - 109 ответов, это говорит о хорошей клиентоориентированной работе. Увеличение клиентской базы более 50 \% пожеланий. Нужно выделить особые пожелания клиентов, которые могут привести к усилению позиций компании и увеличению конкурентоспособности: пожелание было связано с увеличением ассортимента.

Контакты для обратной связи оставили 54 человека. Значит, они готовы получать информационную и рекламную продукцию компании, тем самым и предыдущими ответами клиенты показывают высокую лояльность к предприятию.

Из анкеты были выделены реализуемые желания клиентов, они носят низкобюджетный характер и при должной рекламной кампании и освещении в СМИ вызовут положительный резонанс 116 
и привлечение внимания к предприятию: леденцы к чаю, поздравление Дедушки Мороза для детей-сирот, яблочные вареники, 6 кг вареников яблочных с медом, подарок робота-бэтмена, новые боксерские перчатки, мешок пельменей.

\section{Кейс 8: Гамак}

В результате анализа были получены следующие данные. Постоянными клиентами являются около 50 \% анкетируемых, 28 положительных ответов из 53. Из положительных отзывов о деятельности предприятия в первую очередь стоит отметить, что особенно нравится основная продукция (еда) - 19 ответов, что составляет ниже 50 \%. Отсюда можно сделать выводы, что основными интересами клиентов не является продукция предприятия. После этого следуют положительные отзывы об атмосфере, созданной на предприятии, - 18 ответов, это подтверждает предыдущие выводы о низкобюджетном потребителе и сдвиге вектора интересов от продукции к атмосфере и веселому времяпрепровождению. Положительные отзывы о работе персонала оставили 12 человек. Обслуживанию и ассортименту было уделено мало внимания - 5 положительных ответов.

Общее количество ответов с отрицательными отзывами на вопрос «Что вам не понравилось?» составило 12, что приближается к отметке в $20 \%$, и носит рекомендательный характер к улучшению работы. Их можно структурировать следующим образом. Претензии к обслуживанию и времени - 2 ответа, обращают внимание на курение; внутреннему обустройству - 7 ответа, большие претензии к температурному режиму и просьбой кондиционирования воздуха; к ассортименту - 4 ответа, отсутствию крепкого алкоголя.

Структура новогодних пожеланий заведению показала следующие результаты: желают роста компании и в целом позитивные пожелания - 35 ответов, увеличение клиентской базы - 2 пожелания, это говорит об контингенте потребителей. Нужно выделить особые пожелания клиентов, которые могут привести к усилению позиций компании и увеличению конкурентоспособности: 
внедрение системы кондиционирования, введение детского меню, акций по продвижению.

Контакты для обратной связи оставили 18 человек, это говорит о низкой лояльности к предприятию.

\section{Заключение}

Всего в анкетировании приняло участие 566 человек. Желают роста компании, расширения филиальной сети, географии присутствия и в целом позитивные пожелания. Из этих ответов стоит обратить на такое пожелание, как расширение география присутствия (в микрорайоне Академический), это говорит о желании людей иметь больше возможностей посещать заведения. Увеличение клиентской базы, это говорит об удовлетворенности клиентов и желании оставить о компании хорошие отзывы. Нужно выделить особые пожелания клиентов, которые могут привести к усилению позиций компании и увеличению конкурентоспособности: введении детского меню, просьба об организации акций и мероприятий, создании бонусной карты постоянного покупателя, снижении цены, скидки для студентов. Основные просьбы направлены на ценовую политику предприятия, что можно трактовать как просьбу о модернизации или внедрении дисконтной системы, запросе клиентов на программу лояльности.

\section{Список литературы}

1. Food-court. URL: http://www.food-court.ru/fast-food/restoranibistrogoobsl uzhivaniya/

2. Широченская И. П. Основные понятия и методы измерения лояльности / И. П. Широченская // Маркетинг в России и за рубежом. 2004. № 2. С. 36-45.

3. Liesse J. Brands in Trouble / J. Liesse // Advertising Age. 1992. Dec. 2. P. 16.

4. Schlueter S. Get to the Essence of a Brand Relationship / S. Schlueter // Marketing News. Jan. 20. P. 4. 


\section{Глава 4 \\ ОСОБЕННОСТИ РАЗВИТИЯ РЫНКОВ}

\section{§ 1. От легкой промышленности \\ к индустрии моды: направления \\ развития предприятий отрасли}

Индустрия моды, или фэшн-бизнес, термин не слишком распространенный в профессиональной среде, и специалисты по экономике, управлению и маркетингу, как правило, обходят стороной эту тему в своих трудах. Особенно заметен этот вакуум в российской исследовательской практике, где преобладают статьи в «глянце» беллетристического толка. Ниша научной литературы по индустрии моды представлена незначительным количеством российских авторов, таких как А. Н. Андреева, М.Н.Дымшиц, А. Лебсак-Клейманс. Проблема создания российской одежной индустрии актуальна для научных исследований, поскольку за этим лежит сложная интегрированная система межотраслевых связей.

Глобальная реальность такова, что модная индустрия - это огромная финансовая отрасль, в которой генерируются значительные денежные потоки, есть интересы инвесторов и финансово оформленный спрос потребителей и дистрибьюторов. Мировые бренды фэшн-индустрии с завидным постоянством входят в ТОП 100 самых дорогих брендов, а капиталоемкость отрасли с каждым десятилетием только возрастает. Тем не менее, несмотря на многочисленные дискуссии, в том числе и на самом высоком уровне, эта отрасль по-прежнему не является сферой реальных интересов нашего государства. 
Актуальность представленного исследования может быть дополнена текущими ситуационными факторами: экономической нестабильностью и последовавшая за этим девальвация рубля в конце прошлого 2014 г; геополитическим кризисом, и как следствие, санкции, наложенные на Россию со стороны Западных стран, взятый курс на импортозамещение; пересмотр взглядов на место и роль легпрома в целом и модной индустрии в частности.

Итак, целью представленной работы является определение роли и структуры индустрии моды в разрезе отраслей легкой промышленности, а также на примере компаний, работающих в Свердловской области, проиллюстрировать типичные проблемы, с которыми сталкиваются предприятия отрасли и возможные решения.

Задачами исследования являются:

1. Уточнить место и роль индустрии моды в российской классификации отраслей промышленности.

2. Дать определение ключевых понятий и термина индустрия моды, в том числе с точки зрения основных товарных категорий.

3. Определить основные сегменты, участвующие в создании фэшн-продукта.

4. Сформировать представление об объемах и структуре предложения и спроса на рынке фэшн-товаров.

5. Определить направления деятельности по повышению конкурентоспособности продукции и импортозамещение товаров с высокой добавленной стоимостью.

В советский период в нашей стране эта сфера относилась к так называемой легкой промышленности, а ее деятельность на уровне государства курировало объединенное министерство пищевой и легкой промышленности. И хотя технологически у этих отраслей имеются синергетические связи, тем не менее, переходя к современной трактовке модной индустрии, можно утверждать, что общих потребительских мотивов у этих отраслей не так и много.

Современное представление о легкой промышленности в России имеет хотя и сложную, но все-таки весьма ограниченную структуру, включающую всего две группы производств: текстильное 
и швейное производство, на которые приходится около 80 \% объема выпуска (рис. 6).

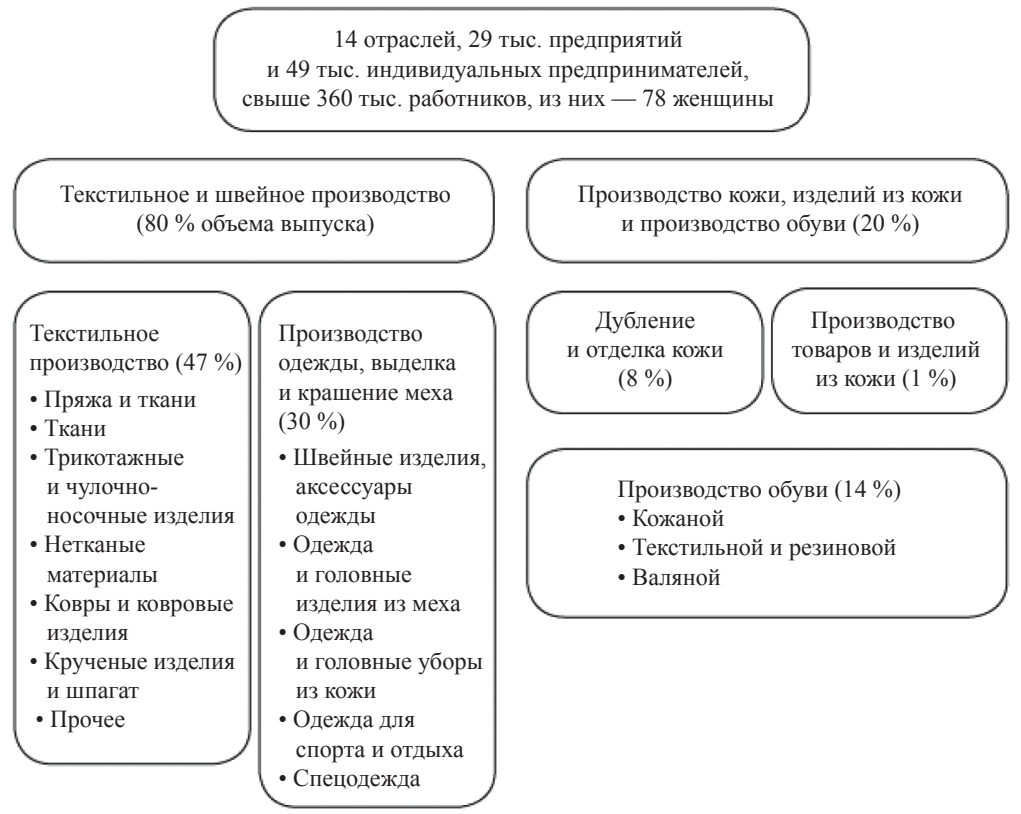

Рис. 6. Структура легкой промышленности России

Таким образом, исходя из определения структуры российской легкой промышленности, можно наблюдать очень слабую корреляцию с тем, что в мировой практике определяют терминами «фэшнбизнес», или «индустрия моды».

Сам термин «фэшн» в российской среде однозначно не определен. Наибольшее распространение он получил в упрощенной, обывательской трактовке, имеющей отношение к модным показам, свету софитов, манекенщицам и селебрити и все тому же «глянцу». Как метко заметила Татьяна Парфенова, модный дизайнер и владелица одноименного модного дома: «Для меня фэшн - это некая русская уловка обозначить узкую отрасль, в которой мои клиенты покупают одежду. А не мебель» [1]. 
Далее, не вдаваясь подробно в этимологию слова «фэшн», рассмотрим кратко ключевые понятия данной сферы и систему взаимосвязей, составляющих вертикально интегрированную производственно-сбытовую цепочку.

Фэшн-объект. В научной среде, рассматривая вопрос о сущности фэшн-объекта, т. е. объекта, подверженного трансформациям моды, разделяют трактовки в узком и широком смыслах. Узкое определение предполагает выделение в первую очередь сегмента «одежда» как «наиболее чистая и древняя форма выражения моды» [2]. Следом выделяют предметы, отражающие индивидуальность человека: обувь и аксессуары (ювелирные украшения, часы, сумки, ремни, очки). В эволюционном процессе развития сферы услуг и массового производства товаров для красоты к фэшн-объектам стали относить и парфюмерию как существенно влияющих на восприятие человека в обществе.

Ближе к 80-м гг. XX в. стала складываться широкая трактовка понятия фэшн-объект. Основной причиной этому стала существенная диверсификация товаров и услуг, на которые распространяется влияние моды, и как следствие, существенная трансформация, согласно ключевым тенденциям (экстерьеры и интерьеры жилых домов, автомобилестроение, гастрономия и продукты питания, массовая музыкальная культура и пр.). В целом, по меткому определению А. Дэниэлза в статье «Фэшн-мерчендайзинг», опубликованной в Harvard Buisness Review: «Мода (фэшн) имеет огромное значение в жизни многих людей просто потому, что является едва ли не всем» [3] (рис. 7).

Майк Исей (Mike Easey), британский маркетолог, в 2002 г. предложил классификацию фэшн-продуктов и фэшн-услуг, состоящую из трех базовых групп [4]:

- первая - одежда, рассматривается как базовый фэшн-продукт (сегменты: верхняя одежда, повседневная одежда, вечернее платье, белье и пр.);

- вторая - родственные фэшн-услуги (консультации по подбору гардероба, имиджмейкерство, парикмахерское искус- 
ство, визаж, ремонт и починка одежды, пластическая хирургия, искусственный загар и пр.);

- третья - родственные фэшн-продукты (обувь, аксессуары, косметика, шарфы, сумки, ремни и пр.).

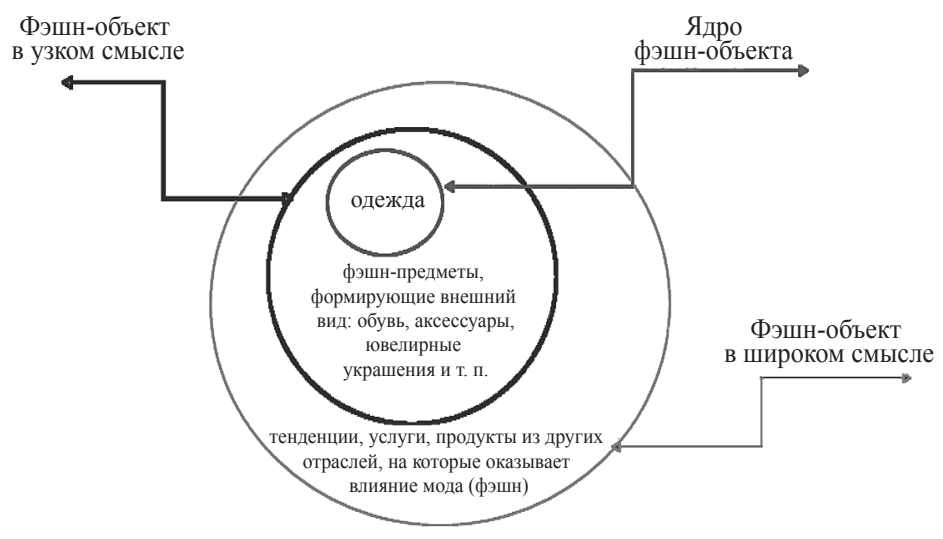

Рис. 7. Определение фэшн-объекта

Вне зависимости от уровня все фэшн-объекты обладают следующими качествами: функциональной утилитарностью, эксклюзивностью, социальное (коллективное) признание, недолговечностью, социальной дифференциацией и рядом других свойств [5; 6].

Фэшн-процесс - следующий термин, может быть определен как «фэшн-бизнес», т. е. целенаправленная деятельность фирм или индивидов по созданию дизайна, управлению производством и сбытом, маркетинговым сопровождением фэшн-объектов.

Данные определения, равно как и их качества и свойства, были сформулированы в рамках так называемых фэшн-теорий, начиная с Т. Веблена (1899) и Г. Зиммела (1904), а также более поздних концепций, таких как Д. Робинсон (1961), Джон и Элизабет Лоу (1984) и др. [7].

Под фэшн-индустрией понимается совокупность творческой, экономической и управленческой деятельности, представляющей собой процесс, имеющий целью дизайн, производство, маркетинг 
и продажу фэшн-продукта [7]. Н. Г. Чаган дополняет вышеприведенное определение: «...с постоянным перемещением условных границ между этапами этого процесса» [8].

Под фэшн-бизнесом же подразумевается деятельность, сконцентрированная на дизайне, производстве и дистрибьюции текстильных и швейных продуктов [7].

Индустрия моды - это сектор сферы услуг, занятый формированием у покупателей образа «модной» продукции, ее производством и реализацией. К модной продукции в узком смысле слова относят группы товаров легкой промышленности, удовлетворяющие личные потребности граждан: одежду, личные аксессуары, парфюмерию и косметику.

Отрадно, что в Стратегии развития легкой промышленности России на период до 2020 г. есть упоминание данного термина: «Некоторые зарубежные компании модной индустрии добиваются успеха не только за счет диверсификации рынков сбыта, но и путем обновления ассортимента и повышения качества выпускаемой продукции, использования для ее выработки новых видов сырья» [9].

Надо отметить, что в фэшн-индустрии хорошо прослеживается временной лаг между практикой, которая задает тон, и теорией, которая запаздывая, тем не менее старается объяснить суть происходящих изменений.

После некоторой вводной относительно теоретического и отчасти исторического экскурса хотелось бы вернуться к классификации отраслей, относимых к легкой промышленности России, и соотнести ее с сегментированием, принятым в мировой практике.

Глобальная индустрия моды выделяет четыре основополагающих сегмента (рис. 8):

1. Первичный сегмент: производители сырья, материалов, фурнитуры, специального производственного оборудования, куда включается производство волокон, нитей, пряжи, ткани, кожи и меха, фурнитуры. Производство текстиля - один из значимых факторов, напрямую влияющий на вид конечного изделия, его позиционирование, цену, статус. 
Первичный сегмент

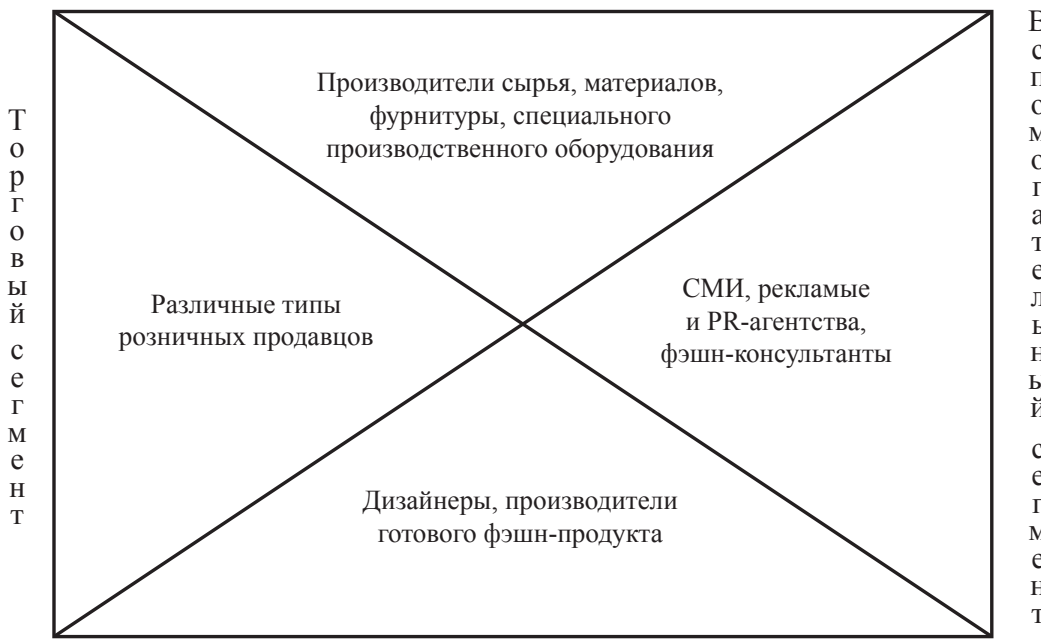

Фэшн-бизнес, или вторичный сегмент

Рис. 8. Сегменты фэшн-индустрии [7]

Образцы, созданные базовым первичным сегментом, демонстрируются на специализированных профессиональных выставках: Texitalia (Милан, Италия), Ideacomo (Комо, Италия), Premiere Vision (Париж, Франция), Interstoff Textile Fair (Франкфурт, Германия).

Технологический процесс создания образцов тканей занимает порядка полутора-двух лет и связан с добывающей, обрабатывающей, химической промышленностью и сельским хозяйством. Немаловажен фактор применения современных высокотехнологичных инноваций в этой сфере, таких как экологичность, термостойкость, износостойкость, возможность утилизации, создания «умных» тканей и пр.

Что касается производства сырья, то, с точки зрения сегмента натуральных тканей, с распадом Советского Союза эта отрасль прекратила свое существование. Хлопчатник в России не выращивается, поэтому хлопчатобумажная промышленность 
полностью базируется на импортном сырье. Хлопок-сырец поступает преимущественно из Узбекистана, также из Таджикистана, Туркменистана, небольшая часть поступает из Азербайджана и Казахстана [10]. А сегмент ненатуральных тканей не развит по причине отставания в этой области отечественной химической промышленности.

В Стратегии развития легкой промышленности на период до 2020 г. представлена статистика положения дел на 2008 г. и перспективы 2020 г. (рис. 9) [9].
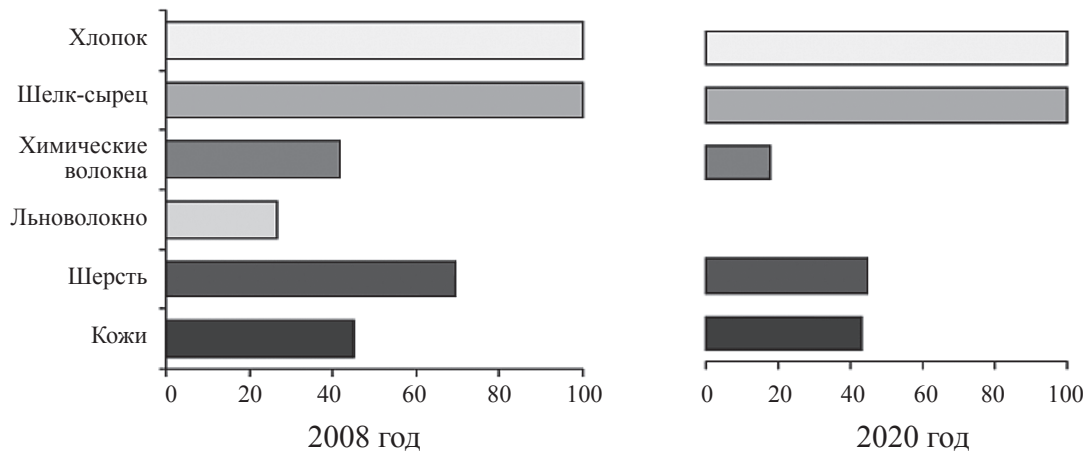

Рис. 9. Доля импорта в потреблении основных видов сырья

Производство фурнитуры - отдельная болезненная тема, поскольку львиная доля поставок приходится на импорт из азиатских стран и еще небольшой процент из Европы. В России практически нет производства одежной фурнитуры, за исключением сегментов военной и прочей спецодежды.

В качестве примера представителя этого сегмента можно рассмотреть Свердловский камвольный комбинат (СКК) - некогда ведущий текстильный комплекс страны, ныне погрязший в битвах за госзаказ, с одной стороны, но пытающийся позиционировать себя как отечественный производитель шерстяных и полушерстяных тканей по уровню не уступающих итальянским - с другой.

В 2013 г. доля заказов силовых ведомств составляла более 40 \% в объеме производства. Однако вступивший в силу в 2014 г. 126 
нормативный акт Правительства РФ переориентировал долю заказов СКК на Брянский комбинат. Следствием этой ситуации был вопрос о закрытии СКК, поскольку нет объективных предпосылок быстрой переориентации производства на выпуск другой продукции из-за сложности и длительности (около 90 дней) технологического цикла. Президент концерна «Уральский текстиль» (учредитель комбината) Игорь Васильков так прокомментировал изменившийся расклад сил в отрасли: «Пятнадцать лет, что мы работаем на рынке ведомственных тканей, наши клиенты (швейные предприятия) были довольны» [11].

Кроме вопросов по формированию ассортимента и проблем с позиционированием, налицо еще одна немаловажная проблема - логистика по стране и попадание на полки тканевых магазинов. Текстильная розница давно отказалась от продаж тканей СКК и предпочитает импортные аналоги, которые до известных курсовых изменений были сопоставимы по цене, выше по качеству и ровности окраса, имели актуальные расцветки, низкие нормы усадки и высокие эксплуатационные характеристики.

Еще одной преградой на пути к розничному сегменту оказались централизованные закупки последних у одного и того же оптового канала продаж. Таким образом, СКК необходимо менять структуру продаж, заключая контракты с крупными оптовыми посредниками, что позволило бы расширить не только локацию продаж, но и увеличить объемы.

Что касается закупок тканей со стороны отечественных производителей одежды, то можно утверждать, что объемы их невелики, поскольку вторичный сегмент фэшн-индустрии в России слишком мал, да и погоня за модным ныне «фаст-фэшн» должна была бы перестроить производство СКК на более гибкие рельсы, поскольку потребовала бы быстрой смены коллекций выпускаемых тканей.

В этой связи можно утверждать, что рынок тканей для одежды специального назначения долее предсказуем и менее рискован.

При этом в Стратегии развития легкой промышленности Свердловской области на период до 2020 г. СКК относится к предприятиям - лидерам отрасли [12]. 
Данный сегмент определенно требует более тщательной аналитики с последующей разработкой стратегии развития, которая непременно коснулась бы технологий, что, как известно, дешево не обходится.

Фэшн-бизнес, или вторичный сегмент, объединяет различных производителей готового модного продукта. Такие компании самостоятельно создают дизайн своих коллекций и закупают ткань, оборудование и другие необходимые материалы у производителей первичного сегмента. Существуют также отдельные компании, которые сами владеют швейными и текстильными фабриками, в которых полностью контролируют производственный процесс конечного продукта, реализуя стратегию вертикальной интеграции. Однако в фэшн-индустрии это скорее является исключением.

Производители фэшн-продукта условно делят на две большие группы: прямые производители и контракторы.

Прямые производители — компании, которые создают собственные бренды, разрабатывают их модели, коллекции, которые затем производят на собственных фабриках. На мировом рынке это такие компании, как, например, Inditex Group (Испания) владеет портфелем брендов и производит все элементы конечного фэшн-продукта на собственных производственных мощностях. В настоящее время крупных компаний такого типа очень мало. Для российского рынка наличие такого рода структур еще большая редкость, полный производственный цикл осуществляют лишь небольшое количество средних и мелких компаний. Такое положение дел может быть объяснено, в частности, эффектом масштаба, поскольку значительные вложения в создание производственных мощностей целесообразно производить только в случае их максимально возможной загрузки в течение года.

Для нашей области примером такой компании является «Студия Т». Это предприятие, специализирующееся на дизайне и производстве трикотажных изделий. В основном женский ассортимент продукции компании имеет ярко выраженную осенне-летнюю сезонность, поэтому компания была вынуждена искать дополнительные сегменты, дабы обеспечить равномерную загрузку 128 
производства. Таким сегментом стала школьная форма, спрос на которую значительно увеличивается в конце лета и начале осени.

Другим позитивным примером компании с полным циклом является компания «Пальметта», которая имеет производственные площади в Екатеринбурге и Первоуральске. Для решения проблемы с загрузкой была выбрана совершенно другая стратегия построение сети фирменных магазинов по всей стране, удачная дифференциация суббрендов и грамотная маркетинговая стратегия. При этом, если коснуться вопроса взаимодействия с первичным сегментом, то 100 \% сырья, материалов и оборудования импортные.

Другая группа компаний данного сегмента представлена крупными производителями, которые предпочитают вкладывать силы в интеллектуальную, творческую (дизайн) и управленческую части процесса. Такие компании, как правило, передают производственную часть работ внешним компаниям, размещая заказы по производству фэшн-продукта на фабриках-исполнителях, оставляя за собой контроль качества произведенного продукта одежды и аксессуаров. Компании-исполнители называются контракторами. Такие компании представляют основу фэшн-индустрии стран третьего мира, в которых считается дешевой рабочая сила $[7 ; 8]$.

Многие российские швейные фабрики после распада межотраслевых связей в 90-х гг. XX в. хотели стать такими контракторами и работать на давальческом сырье. Однако проблемы с обновлением парка оборудования и более высокая стоимость рабочей силы не позволили реализовать такие планы. В Свердловской области швейное производство в советский период было представлено достаточно широко: 2 фабрики в Екатеринбурге (осталась одна и занимает 1 цех в здании, которое когда-то полностью принадлежало ей), в Дегтярске, Ирбите, Карпинске и ряде других городов. В большинстве случаев они либо ликвидированы, либо влачат жалкое существование.

«Сегодня западные производители уже размещают заказы на фабриках Украины и Белоруссии. В ближайшее время они начнут использовать и возможности отечественной швейной 
индустри», - такое мнение высказала г-жа Гришина, дизайнер и владелица одежной сети Xenia. По ее мнению, «как только такие компании, как Inditex, H\&M, Top Shop, запустят собственное производство в России, конкурировать с ними будет намного сложнее» [1].

Можно выделить подгруппу компаний, которые помимо разработки дизайна, производства и продажи фэшн-продукта занимаются продажей лицензий на использование своего фирменного наименования (бренд-нейм). Для российских брендов это пока явление уникальное.

О следующих двух сегментах имеется достаточно много научной и практической литературы, поэтому обобщим главные тенденции.

2. Торговый сегмент: объединяющий розничных продавцов фэшн-продукта, включает бутики, специализированные магазины, торговые сети, универмаги, стоки, фирменные магазины, директмаркетинг, ТВ-магазины, и, конечно, всевозможные формы интернет-торговли. Именно розница являет собой тот лакомый кусок, в котором генерируется основная прибыль.

Интерес представляет тот факт, что среди каналов сбыта на рынке одежды значительной место занимает нецивилизованная розница. Хотя доля вещевых рынков в модели потребления россиян постепенно снижается, этот канал остается зачастую единственным местом покупки одежды в малых населенных пунктах и городах с населением менее 100 тыс. человек. Снижение доли рынков происходит преимущественно за счет все более динамичного развития сетевой розницы в средних и крупных городах в регионах России (рис. 10).

При этом цивилизованная розница в нижнем и среднем ценовых сегментах предлагает, как правило, гораздо более конкурентные цены. Так, цены на рынках на 15-20 \% выше цен на аналогичные товарные категории в таких магазинах сетевой розницы в нижнем ценовом сегменте, как Sela, Gloria Jeans и Jennyfer. Tем не менее на вещевые рынки в 2015 г. все еще приходится около $35 \%$ [13]. 


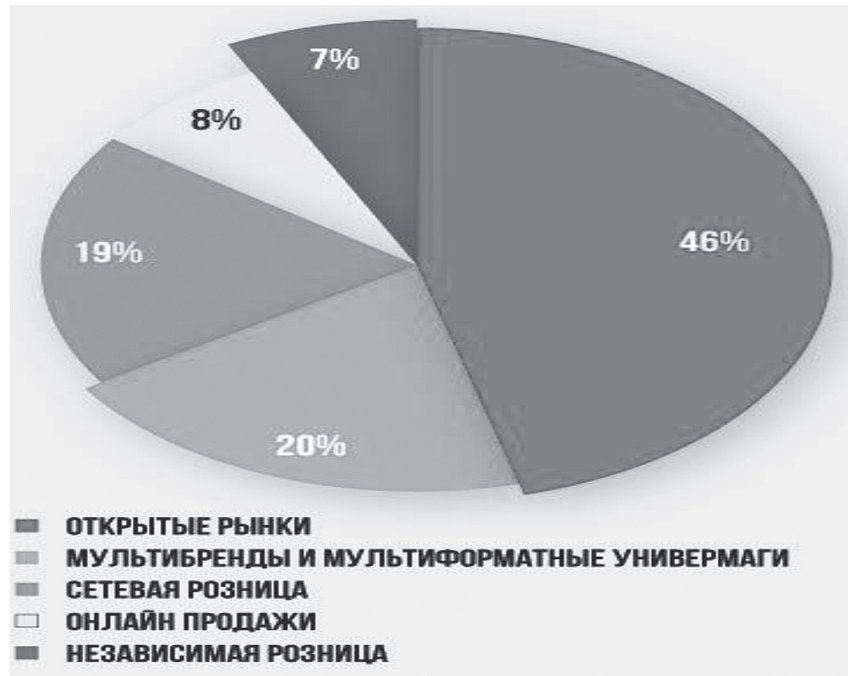

Рис. 10. Удельные доли каналов сбыта на российском рынке женской одежды, 2012 г.

Если рассмотреть по онлайн-каналам продаж, то, по данным РБК.research, наиболее активно растущим является именно Fashion-сегмент российского рынка электронной коммерции, который за прошлый год вырос на 42,4 \%, или 21,9 млрд руб. до 73,7 млрд руб. [14].

За последние 3-4 года fashion-сегмент вырвался в лидеры интернет-рынка. Его главное преимущество — огромный (особенно в сравнении с офлайном) ассортимент. Сейчас в онлайне одежду покупают 47,8 \% интернет-шоперов, или 7,4 млн россиян. Это самый крупный сегмент по числу покупателей. За ним уже идут бытовая техника и товары для кухни (45,0 \%), цифровая и компьютерная техника - 42,7\%.

Наибольшая доля в сегменте fashion (65,1 \% продаж) принадлежит одежде. За год она выросла на 4,7 процентных пункта (п.п.). Продажи обуви в 2013 г. потеряли по сравнению с 2012 г. 5,8 п.п. и составили 21,4 \% рынка. Продажи аксессуаров увеличились на 1,3 п.п. - до 13,5 \% от всего сегмента. В денежном эквиваленте 
структура российского рынка интернет-торговли одеждой, обувью и аксессуарами в 2013 г. выглядела так (рис. 11):

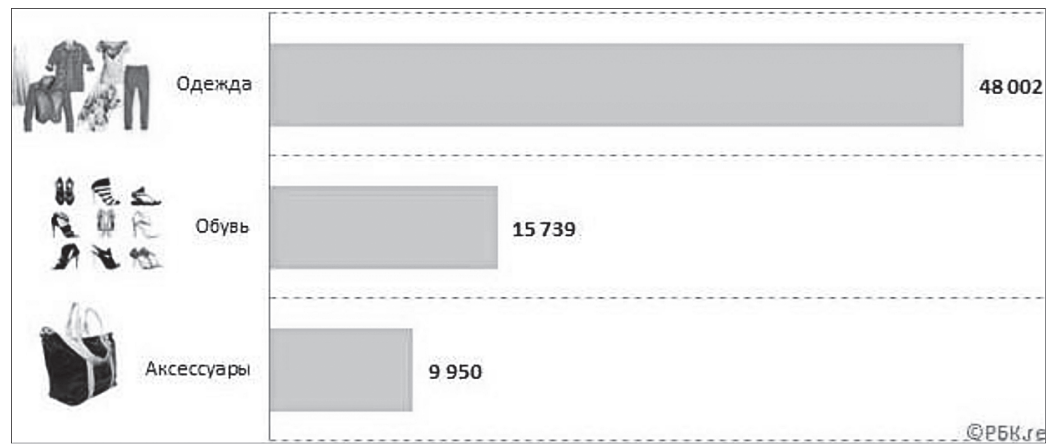

Рис. 11. Структура российского рынка интернет-торговли одеждой, обувью и аксессуарами в 2013 г. в денежном эквиваленте [14]

Драйверами роста рынка в последние годы стали:

- серьезные инвестиции в сегмент интернет-торговли;

- высокий спрос из регионов;

- улучшающийся сервис (бесплатная доставка, примерка перед покупкой, возможность возврата).

Российский рынок интернет торговли активно использует все достижения глобальной паутины, что сопровождается расширением форматов интернет-торговли: классические интернет-магазины, социальные сети, сайты совместных закупок.

3. Вспомогательный сегмент фэшн-индустрии - это та верхушка айсберга, которую видно и невооруженным глазом. Он сформирован из специализированных коммуникационных каналов, таких как:

- он- и офлайн-пресса, профессионально обозревающей мир моды. Здесь можно выделить подгруппу печатных СМИ, которые представлены модными глянцевыми журналами (международные издания, такие как Vogue, L'Officiel), и профессиональные издания (узкопрофессиональные издания, которые специализируются на определенных сегментах 
фэшн-бизнеса и регулярно ведут большие аналитические обзоры);

- телевизионные каналы такие, как профессиональный Fashion TV(FTV), и для широкой публики (MTV, молодежные телеканалы);

- подготовка рекламных материалов, генерирование новостных поводов и организация специальных мероприятий, таких как пресс-конференции, показы, выставки. Такие услуги оказывают специализированные рекламные агентства и PR-агентства. Они же подбирают профессионалов высочайшего класса, среди которых фотографы, специализирующиеся на модных съемках, дизайнеры рекламных объявлений, копирайтеры, сценаристы и постановщики фэшн-шоу, а также специалисты по информационной поддержке событий любого уровня.

Построение таких точек контакта с потребителями может происходить на разных уровнях: от локальных мероприятий для узкого круга лиц до сверхмасштабных «ковровых бомбардировок» рекламой по всем коммуникационным каналам.

Еще одним направление этого сегмента является фэшн-консалтинг. Он связан с оказанием различного рода информационных услуг: прогнозирование тенденций, сбор и систематизация информации по тканям, цветовым решениям, трендам и прочее. А в России ведущим агентством является Fashion Consulting Group (г. Москва).

Характеризуя предложение товаров отечественного рынка продукции легкой промышленности, складывается не очень радужная картина: в целом почти 80 \% приходится на легальный и нелегальный импорт, а также на неучтенное производство. В итоге на собственно российское производство приходится всего 20,3\% (рис. 12) [15].

Подводя промежуточный итог обзора сегментов, формирующих предложение в индустрии моды, можно однозначно утверждать, что сложная многоуровневая система интеграционных связей в этой отрасли нуждается в глубокой проработке каждого звена 
в частности и обеспечить динамичное развитие всего комплекса задействованных отраслей.

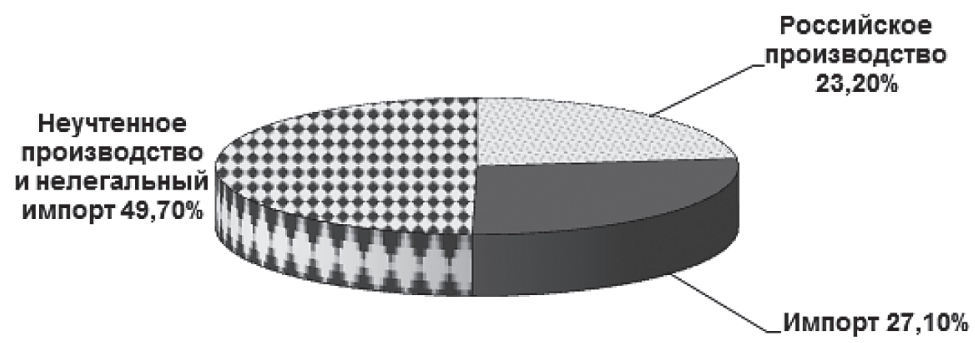

Рис. 12. Структура российского рынка в 2007 г.

С точки зрения спроса в России ситуация следует мировой динамике. Так, по данным Росстата, рынок товаров легкой промышленности в 2009 г. составил чуть более двух триллионов рублей и по своим размерам уступал только рынку продовольственных товаров [15].

Несмотря на кризисы, рынок моды в России является одним из самых динамично развивающихся в мире. В 2013 г. эксперты оценили его оборот в 53 млрд долл. (табл. 8) [16].

Таблица 8

Непродовольственные товары в структуре расходов населения (\%)

\begin{tabular}{l|c|c|c|c|c|c|c|c}
\hline \multicolumn{1}{c|}{ Виды товара } & 2006 г. & 2007 г. & 2008 г. & 2009 г. & 2010 г. & 2011 г. & 2012 г. & 2013 г. \\
\hline $\begin{array}{l}\text { Непродовольственные } \\
\text { товары }\end{array}$ & 33,74 & 35,13 & 35,99 & 37,37 & 36,5 & 35,57 & 36,88 & 37,12 \\
\hline Одежда и белье & 5,19 & 5,27 & 5,13 & 5,55 & 5,48 & 5,59 & 5,55 & 5,46 \\
\hline $\begin{array}{l}\text { Меха и меховые } \\
\text { изделия }\end{array}$ & 0,56 & 0,74 & 0,70 & 0,72 & 0,65 & 0,66 & 0,66 & 0,69 \\
\hline Трикотажные изделия & 1,29 & 1,30 & 1,32 & 1,31 & 1,34 & 1,33 & 1,33 & 1,27 \\
\hline $\begin{array}{l}\text { Обувь кожаная, } \\
\begin{array}{l}\text { текстильная } \\
\text { и комбинированная }\end{array}\end{array}$ & 2,52 & 2,55 & 2,52 & 2,53 & 2,54 & 2,56 & 2,50 & 2,36 \\
\end{tabular}


К особенностям формирования спроса можно отнести климатические условия и особенности менталитета, которые заставляют россиян постоянно поддерживать траты на одежду и обувь на уровне до $10 \%$ в общей структуре расходов домохозяйств независимо от финансового статуса.

При этом женская одежда - не только самый крупный, но и самый зрелый, насыщенный игроками, высококонкурентный сегмент рынка. По итогам 2013 г. стоимостный объем рынка женской одежды превысит 40 млрд долл. Из года в год растут рынки мужской и детской одежды, причем последний растет более высокими темпами, что объясняется не только ростом стоимости товаров, но и положительной демографической динамикой.

Так или иначе, но о структуре спроса, поведенческих мотивах и предпочтениях имеется достаточно много исследований, классификаций и систематизаций. Итогом описания ситуации на рынке является его главная характеристика - рынок растущий, а значит, согласно экономическим законам на нем есть место и отечественным производителям.

В какой-то степени задача повышения эффективности предприятий отрасли - это стратегическая задача, касающаяся обеспечения безопасности страны, наряду с продовольственной безопасностью. Поэтому Стратегия развития легкой промышленности России на период до 2020 г. предусматривает доведение доли отечественных производителей в структуре предложения до минимум $51 \%$.

Для развития благополучного сценария уже упомянутая стратегия содержит ряд предложений, в том числе и меры господдержки. К этому можно добавить следующие предложения:

- определить наиболее перспективные сегменты для импортозамещение;

- создать условия для развития кооперации и различного рода интеграции отечественных предприятий (например, единая интернет-площадка размещения заказов и оказываемых услуг), что позволит повысить объем загрузки мощностей, что при сокращении размера партий весьма значимо; 
- требуется адресная поддержка предприятий, функционирующих во всех указанных выше сегментах;

- поддержать компании, создающие продукт с уникальным дизайном (помимо налогов и финансирования). Как, например, снижение стоимости аренда в торговых центрах для отечественных производителей, стоимости рекламных мест;

- развивать культуру потребления через СМИ (экологизация, предпочтение натуральным волокнам, опасность химических соединений в тканях, утилизация);

- обучать практическим навыкам менеджмента, маркетинга и брендинга на кейсах лучших компаний мировой модной индустрии;

- поддержка региональных конкурсов, в том числе профессионального мастерства.

На примере фэшн-индустрии можно проиллюстрировать глобальную тенденцию изменения границ и состава отраслей, которые в настоящее время определяются не технологическими процессами, а прежде всего конечными потребителями. Именно грамотная потребительская сегментация и посторенние на ее основе работающих бизнес-моделей позволят выделить из бесформенной массы под названием «легкая промышленность» конкурентоспособные комплексы с четким вектором клиентоориентированности. А вертикальная интеграция и умеренная диверсификация создадут межотраслевую систему контрактов, направленную на развитие импортозамещающих производств.

\section{Список литературы}

1. Москаленко Л. Дизайн в розницу / Л. Москаленко // Эксперт. 2006. 3 июля. № 25 (519).

2. Robinson D. E. Fashion Theory and Product Design / D. E. Robinson // Harvard Business Review. 1958. № 36 (November-December). P. 126-138.

3. Daniels A. H. Fashion Merchandising / A. H. Daniels // Harvard Business Review. 1951. № 29 (May). P. 51-60. 
4. Метляева Т. В. Имиджевые характеристики модного продукта / Т. В. Метляева, И. Л. Клочко // Фундаментальные исследования. 2014. № 8-2. C. 381-385.

5. Sproles G. B. Fashion Theory: a Conceptual Framework / G. B. Sproles // Advances in Consumer Research. 1974. Vol. 1. Is. 1. P. 463-471.

6. Analysing Fasion Life Cycles Principles and Perspectives // Journal of Marketing. 1981. Vol. 45 (Fall). P. 116-124.

7. Андреева А. Н. Дизайнерские бренды в фэшн-бизнесе / А. Н. Андреева. 2-е изд. СПб., 2008. 256 с.

8. Чаган Н. Г. Brand-Building фэшн-индустрии и фэшн-бизнеса / Н. Г. Чаган // Прикладная культурология: Калейдоскоп идей : ежегодник / под ред. И. Г. Хангельдиевой, Н. Г. Чаган. М., 2010. С. 27-40.

9. План мероприятий по реализации Стратегии развития легкой промышленности России на период до 2020 года. Утв. приказом Министерства промышленности и торговли РФ от 24 сентября 2009 г. № 853.

10. Печаткина Е. Ю. Особенности предприятий легкой промышленности / Е. Ю. Печаткина // Вестн. Челяб. гос. ун-та. 2012. № 8 (262). Экономика. Вып. 36. С. 117-123.

11. Пермяков А. Свердловский камвольный комбинат лишили $40 \%$ заказов / А. Пермяков // Деловой квартал. 4 декабря 2014 г. [Электронный pecypc]. URL: http://ekb.dk.ru/news/sverdlovskiy-kamvolnyy-kombinatlishili-40-zakazov-236907884

12. Стратегия развития легкой промышленности Свердловской области на период до 2020 года разработана в соответствии с постановлением Правительства Свердловской области от 27.08.2008 № 873-ПП «О Стратегии социально-экономического развития Свердловской области на период до 2020 года».

13. Федяков И. Обильно одетые женщины / И. Федяков // Эксперт онлайн. 03 марта 2014 г. [Электронный ресурc]. URL: http://expert.ru/ siberia/2014/20/obilno-odetyie-zhenschinyi

14. Российский интернет-рынок одежды сегодня. [Электронный pecypc]. URL: / http://oborot.ru/news/13803/24

15. Кащеев O. Тезисы доклада заместителя директора департамента лесной и легкой промышленности Минпромторга России на Неделе моды в Москве. 21 октября 2010 г. / О. Кащеев [Электронный ресурс]. URL: http://old.minpromtorg.gov.ru/industry/light/53

16. Лябина А. Санкции лишь подогрели в мире интерес к российской фэшн-индустрии // Комсомольская правда. 23 ноября 2014 г. [Электронный ресурc]. URL: /http://www.kp.ru/daily/26311.7/3189448 


\section{§ 2. Основные тенденции потребительского поведения современной молодежи}

Параграф посвящен анализу особенностей потребительского поведения молодежи. Потребительское поведение рассматривается как действие, связанное с выбором и приобретением продуктов, в котором выражаются индивидуальные предпочтения, мотивы, установки, возможности людей. В материале анализируется отношение молодежи к процессу потребления в целом, показному потреблению, рекламе. Автор ставил перед собой цель - изучить особенности потребительского поведения российской молодежи на региональном рынке товаров и услуг, выявить степень влияния социальных характеристик молодежной аудитории на формирование их потребительских практик и предпочтений.

В полевой части исследования использован комплекс качественных (глубинные интервью) и количественных (опросы и анкетирование исследований, наблюдений, обработка вторичной информации (статьи газетные, аналитические обзоры маркетинговых и социологических исследований потребительского поведения и спроса). Теоретико-методологической базой исследования явились работы по вопросам жизненного стиля (В. Б. Звоновский, С. Луцева), социальной стратификации (Г. М. Мкртчян), поведенческих установок (М. А. Ядова), потребительское поведение (В. И. Ильин).

\section{Специфика потребительского поведения: региональный аспект}

Потребительское поведение молодежи постоянно меняется в пространстве и времени, поскольку постоянно видоизменяются ценности и общий стиль жизни молодых людей. М.В.Ядова считает, что в период трансформаций, переживаемый в последние десятилетия российским обществом, говорить о каких-либо общепринятых стандартах поведения крайне сложно [1]. По заверению В. С. Магун и А. З. Литвинцевой, «жизненные цели молодежи и планируемые средства их достижения являются важным фактором ее социальной активности и в то же время индикатором 138 
фундаментальных перемен, происходящих в современном российском обществе» [2].

Молодежь представляет собой активную, динамичную группу потребителей. Молодежь, обладая таким социальными характеристиками, как восприимчивость к инновациям, максимализм, изменчивость ценностей, склонность к подражательству и другие, конструирует собственные стили и образы потребления, активно вовлекается в разнообразные потребительские практики. Свое внимание на молодежь и ее проблемы обращают не только социологи, психологи, но и маркетологи, которые рассматривают молодежь в качестве отдельной целевой аудитории, отмечая ее перспективность для финансового и производственного секторов. Таким образом, есть острая необходимость в знаниях о потребительском поведении молодежи как крупной социальной общности активных потребителей товаров и услуг, обладающих большим потребительским потенциалом, непосредственно влияющих на развитие потребительского рынка, а значит, и на состояние производительных сил.

Необходимость понимания молодого потребителя обусловлена тем, что помогает изучить потребительские потребности и предпочтения данного демографического сегмента, а также понять, какие продукты/услуги востребованы сейчас и будут востребованы в ближайшее время молодежью.

Новые ценности с учетом базовых факторов, влияющих на потребительское поведение молодежи, заключаются в том, что современные молодые люди стали более динамичными и мобильными, большое внимание уделяют развитию карьеры, в среде молодежи модно одновременно учиться, работать, быть всесторонне развитым и начитанным человеком и активно проводить досуг.

Потребительское поведение является формой экономического поведения человека и в полной мере отражает социальный статус группы и личности. Можно сказать, что маркетинг включает в себя разработку технологий реакции фирмы на поведение потребителей. Важное место в разработке теории современного маркетинга принадлежит Ф. Котлеру [3]. Он выделил и описал жизненные 
циклы семьи и особенности потребления на каждом из этапов, проиллюстрировав таким образом теорию жизненных циклов Модильяни. По мнению Ф. Котлера, на решениях покупателя сказываются и его внешние характеристики, особенно такие, как возраст, этап жизненного цикла, род занятий, экономическое положение, тип личности и представление о самом себе. Переход России от распределительной системы ресурсов и благ к системе свободного рыночного производства и потребления радикально изменил потребительский рынок товаров и услуг. Изменились условия жизни всех социальных групп и слоев российского общества, включая молодежь. Рыночные реформы привели к значительному расслоению российского общества как по уровню доходов, так и по уровню и качеству жизни. Основной формой поведения населения в условиях глубинной трансформации общества стала адаптация к новым социально-экономическим условиям. В. В. Радаев характеризует общество потребления как разнообразие реализуемых товаров и услуг и ускоряющееся обновление видов товаров [4].

Современная молодежь представляет собой поколение, мировоззрение которого формировалось под воздействием перехода к рыночной системе хозяйствования и общественных отношений в экономике, политике, культурной и духовной сферах, и новые реалии современной жизни не требуют адаптации, необходимой для более старших поколений россиян. Изменение роли и места потребителей в экономической системе существенно меняет ее характер, - отмечал В. И. Ильин [5]. Она теснейшим образом переплетается с культурой потребления, которая превращается в материальную экономическую силу. Общество потребления порождает массовую потребность в индивидуализации. По мнению Ж. Бодрийяра, «монополистическая концентрация промышленности уничтожила реальные различия между человеческими существами, гомонизировала личности и продукты. Именно на базе потери различий возник культ различий» [6].

Молодежь в структуре российского населения составляет свыше 20 \%. Как социально-демографическая общность молодежь не является однородной. Мы можем дифференцировать молодое 140 
поколение по полу, возрасту, образованию, материальному положению, месту в социальной структуре общества, ценностным установкам, структуре и степени удовлетворения потребностей. Расслоение молодежной общности обуславливает специфику потребления в зависимости от социального статуса, положения в системе социально-трудовых отношений, величины и способа получения дохода. Молодежь отличается высоким уровнем социальной мобильности, а изменение статуса (семейного, образовательного, трудового и т. д.) молодого человека связано с возрастанием потребностей, которое далеко не всегда сопровождается ростом возможностей, достаточных для их удовлетворения. Это нередко провоцирует девиантное поведение - правонарушения, направленные на удовлетворение потребностей противозаконным путем.

Ценности, которые принимают и отвергают молодые россияне, во многом определяют их поведение как потребителей. Стоит отметить, что в последнее время в головах молодежи произошла переориентация от предпочтения нематериальных ценностей материальным. Это привело к стремлению к реальным конкретным целям: обеспечению достойного социального положения, материального благополучия, возможностей культурного досуга. Молодые люди нацелены на повышение уровня жизни, получение достаточно высокого уровня образования, профессионального и карьерного роста, у них отсутствуют стойкие стереотипы в экономическом мышлении, свойственные более старшим поколениям. Молодежь является наименее консервативной частью общества. Можно с уверенностью говорить о наличии у молодежи установок на перемены и инновационность. Склонность к новаторству не может не сказываться на стиле потребительского поведения молодежи. Большинство новинок, выходящих на рынок товаров и услуг, ориентированы именно на молодых потребителей, открытых новому и не боящихся экспериментов.

В современном динамично развивающемся мире возрастает роль молодежи как «проводника» информационных потоков, новых знаний и навыков, формирующих новые модели ее 
поведения, в том числе потребительского. Изменения, произошедшие в социальном положении российской молодежи, оказывают непосредственное влияние на ее сознание. Заметные сдвиги произошли в мотивационной структуре, структуре потребностей, потребительском поведении. Нынешнему поколению молодежи предстоит стать «социальной результирующей прошедшего века», носителем социального опыта предыдущего столетия.

С декабря 2007 г. по настоящее время усилиями студентов экономического факультета Уральского госуниверситета проводится учебное исследование, ориентированное на выявление повседневных потребительских предпочтений российской молодежи. Екатеринбург - столица Уральского федерального округа, промышленный центр с развитой инфраструктурой. Население города (около 1,5 млн) обладает сложившейся структурой потребительского выбора и предпочтений, знанием конъюнктур рынков, достаточно высокими, но дифференцированными доходами (средний доход 24 тыс. руб.). На данном этапе целью исследования является выявление специфики динамических процессов, характеризующих поведение изучаемой группы. В качестве опрашиваемых были выбраны три категории лиц: студенты высших учебных заведений; студенты колледжей; учащиеся школ, проживающие в городе Екатеринбурге. Студенты - одна из наиболее динамичных групп потребителей, оказывающая существенное воздействие не только на остальную молодежь, но и на широкие слои населения за пределами этой возрастной группы. Нередко студенты выступают в качестве пионеров потребления, что делает эту социальную группу особенно интересной для исследователей. При формировании выборки была сделана попытка отобрать людей, способных быть экспертами повседневности для изучаемой группы населения. Это значит, что информант должен быть способен рассказать не столько о своей жизни, сколько о том, как живут люди в его среде, люди его стиля и образа жизни.

На материале глубинных интервью и наблюдений был осуществлен анализ процессов формирования потребительских структур повседневной жизни в самых разных сферах: в формировании 
ценностных ориентиров, в конструировании обыденных предпочтений, в формировании лояльности к брендам.

Исследование имело эмпирический, прикладной характер, но при этом не предполагало выработку каких бы то ни было рекомендаций. Его цель - получение информации для размышления в отношении потребления современной молодежью конкретных товаров и услуг: образования, современных средств связи, компьютеров, одежды, напитков, табачных изделий, автомобилей и т. д.

\section{Основные итоги исследования (2011-2013 гг.)}

Рассматривая доход молодежи, необходимо учитывать также «иждивенческий фактор» - зависимость удовлетворения потребностей от материальных возможностей родительской семьи. Действие этого фактора распространяется прежде всего на представителей учащейся молодежи, не обладающих экономической самостоятельностью. $40 \%$ респондентов не имеют собственного источника дохода и живут за счет временных приработков и помощи родителей. Месячный доход составляет в среднем 3000-5000 руб., однако студенты экономических и технических специальностей более склонны к поиску дополнительных средств к существованию.

Абсолютно для всех респондентов важен их внешний вид. Они осуществляют выбор одежды, определяясь вкусом, а не модой, но чтобы стиль был выдержан. Марки и место покупки имеют значение, так как бренд превратился в центральный элемент потребительского рынка и потребительского поведения. Чаще всего выбор падает на иностранных производителей товаров широкого потребления среднеценового уровня.

Бренд в представлении современных студентов отсылает к таким понятиям, как надежность и престиж. Борьба за престиж и имидж часто приобретает форму демонстративного потребления. Такая стратегия поведения особенно характерна для студентов экономических специальностей и технарей-старшекурсников, уже имеющих стабильный доход. Ими приобретаются автомашины, высокотехнологические изделия зачастую не по функциональным, 
а по имиджевым признакам. В то же время в ответах респондентов, характеризующих отношения с брендом, есть и одно «но», это цена. Если большинство опрошенных предпочитают фирменные товары, то практически единицы готовы за них переплачивать. В этой связи повышается интерес к распродажам, что соответствует мировым тенденциям. За последние десять лет в мире вдвое увеличился сегмент людей, которые хотят покупать товары престижных брендов, при этом только на распродажах по умеренной цене.

Большинство опрошенных покупают одежду в торговых центрах и бутиках. Стиль - классика и кежуал. Гуманитарии склонны к созданию индивидуального стиля в одежде, а остальные руководствуются принципом «просто, но со вкусом».

Абсолютное большинство респондентов питаются дома (вузовские столовые и буфеты студенты посещают в дневное время ежедневно, а кафе и фаст-фуды в среднем раз в неделю). Студенты отдают предпочтение вкусной домашней еде.

Но в то же время можно отметить такую особенность в изменении привычек питания: прием пищи все меньше становится простым физиологическим процессом и все больше относится к понятию «стиль жизни». 45 \% респондентов заявляют, что при приготовлении пищи они стремятся к самовыражению, и их доля постоянно растет. Все больше студентов открывают для себя кухни других стран мира, любители которых среди опрошенных составили $65 \%$. Это преимущественно японская и итальянская кухни. Выбор кухни осуществляется исходя из специфики предложения. С 2008 г. спектр предложения национальных кухонь в Екатеринбурге расширился (появились узбекские, грузинские, армянские рестораны). Таким образом, в основе изменяющихся привычек питания лежит не только доход и разнообразие продуктов и заведений общественного питания, но и изменения стиля жизни.

Что касается алкоголя, то технари пьют все, гуманитарии мало, а экономисты - «респектабельные напитки». Однако серьезной зависимости от алкоголя у студентов нет.

Абсолютное большинство отрицательно относится к наркотикам, однако достаточно высок процент людей, употребляющих наркотики: около 4 \% (особенно гуманитарии). 
Курит ровно половина респондентов, в основном легкие сигареты. Однако последнее время характерна тенденция к снижению численности курящей молодежи. Это связано с активной пропагандой в СМИ различной рекламы о вреде курения, а также возросшей популярности здорового образа жизни. Все чаще молодые люди после учебы, работы регулярно занимаются спортом, фитнесом, йогой.

Абсолютное большинство желает проводить время с любимым человеком. Кино и театры посещают редко, особенно театры. Самый любимый жанр кино - комедии и ужасы (экономисты и гуманитарии - мелодрамы и элитарное кино). В клубы ходят редко, однако чаще, чем в кино и театры.

Технари предпочитают учебную литературу, а гуманитарии и экономисты - художественную (особенно классика). Технари не читают журналы, но большинство гуманитариев и экономистов читают глянцевые журналы. Среди экономистов упоминаются журналы экономической и политической тематики.

Самыми общительными признаны гуманитарии, однако часто люди общаются только с определенным кругом лиц - друзьями, однокурсниками.

Подавляющее большинство молодых людей пользуются общественным транспортом, информация о личном транспорте встречаются чаще всего у экономистов (28 \% опрошенных).

Наиболее популярной маркой сотового телефона является Nokia, но все чаще респонденты называют Apple. Основным оператором признана местная дешевая и не очень качественная связь. Интернет имеют все респонденты, используя его для работы/ учебы и общения.

Половина студентов живет с родителями, треть живет в общежитии, остальные имеют свою собственную квартиру (высок процент у экономистов) или снимают. Молодежь не очень активно заботится об убранстве своего жилища.

При поступлении в вуз абсолютно все руководствовались престижностью учебного заведения и выбранной специальностью. Дополнительные курсы посещают лишь только треть всех 
респондентов, однако если посещают, то исключительно языковые курсы.

В основном студенты не готовы жертвовать учебой ради работы. «Молодежь лучше адаптируется к рыночным условиям, отмечает В. В. Павлова, — чем старшее поколение, глубже входит в современную экономическую систему» [7].

Будущее связывается прежде всего с интересной работой. Затем идет перспектива карьеры, а для экономистов - высокая заработная плата. Как отмечает Г. М. Мкртчян, «молодые люди планируют предложить на рынке труда прежде всего свое будущее образование и высокую квалификацию в качестве “собственноресурсного" дивиденда занятия определенной статусной позиции. Важнейшим средством получения данного статуса, в их представлении, является достижение материального благополучия. Именно этот показатель социальной стратификации определяет значимость поведенческих приоритетов образовательной цели» [8].

Таким образом, индивидуальное потребление - это производство, где субъектом выступает индивид, воспроизводящий себя как человека.

Реакция других на потребительское поведение индивида это мощный фактор, заставляющий его осуществлять то, что ему хочется, постоянно оглядываясь на окружение, делая это так, как принято, избегая того, что может вызвать осуждение. Значит, даже в самых простых актах удовлетворения своих природных потребностей индивид потребляет не только для себя, но и для других, воспроизводя этим себя как члена той или иной социокультурной общности.

Стилевой выбор современной молодежи вытекает не из возможностей, а из желаний и вкусов. Этот вкус, по мысли П. Бурдье, формируется под структурным давлением [9]. Модели потребления современной молодежи все больше выстраиваются под влиянием модных журналов и рекламы. Девиз «глянцевой и рекламной» идеологии: «Я потребляю, следовательно, существую». Глянцевые журналы и многие передачи ТВ выполняют функцию агентов потребительской социализации. Их идеология - это 146 
создание программ индивидуального успеха, символами которого выступают престижные стили потребления.

Идеология общества потребления предлагает простой и понятный смысл жизни: потребляя, ты идешь к своей самореализации и личному счастью, попутно укрепляя экономику страны, помогая отечественному спорту и т. д.

Реклама формирует консьюмеристскую идеологию и внедряет ее в сознание масс с помощью бесконечно повторяемых призывов. Это гиперреальность, претендующая на приоритет над реальностью. Так как рекламируемые товары и стили жизни обладают несомненным превосходством над тем, что уже есть, они задают ориентиры устремлений, превращаются в индивидуальные программы жизненного успеха.

На фазе производства человека как члена общества потребление все больше теряет свой чисто утилитарный характер. Общество потребления начинается там, где борьба за физическое выживание отходит на задний план, уступая место потреблению символов, конструированию идентичностей. В таком обществе потребляют не всегда ради физического выживания, а во имя удовлетворения символических причуд и потребностей.

Оно направляется на обеспечение места в разных общественных структурах, на символическое обозначение своей принадлежности к той или иной группе или слою. В результате в структуре потребления все более заметное место начинает играть производство символов. Для «хорошей» одежды уже совершенно недостаточно быть теплой и удобной, она уже оценивается как текст, читаемый, интерпретируемый окружающими.

\section{Заключение}

Резюмируя вышесказанное, можно подвести итоги и выявить следующие тренды потребительского поведения молодежи:

1) Активно формируется рынок статусных навыков. Статусные товары перестают быть эффективными социальными маркерами. «Что ты имеешь?» - вопрос вчерашнего дня. В настоящее время гораздо важнее ответ на вопрос: «Что ты умеешь?» Вместо 
статусных товаров появляются новые статусные навыки, такие, например, как знание иностранных языков, умение танцевать сальсу, заниматься йогой, разбираться в вине, уметь высококлассно управлять автомобилем или мотоциклом, хорошо фотографировать, готовить изысканные блюда и т. п.

2) Рост культуры ухода за собой, который спровоцировал среди молодежи значительное увеличение спроса на косметические и гигиенические продукты, салоны красоты, спа-салоны, студии загара и косметические услуги в целом. Молодежь стала выглядеть очень ухоженной. Опять же при некотором влиянии родительских капиталов.

3) В последние годы потребление смещается в сторону более здоровых и натуральных продуктов питания - экологически чистых продуктов питания, органического питания и продуктов, дополнительно обогащенных витаминами, минеральными веществами, бифидокультурами. Уже не модно пить газировку, она вредна для здоровья. В среде молодежи модно утром есть мюсли, пить в кафе и ресторанах «фреши» — отжатые свежие соки, а на работу или лекции брать с собой биойогурты.

4) Увлечение гастрономией, высокой кулинарией и мода на гурманство. Для современной молодежи, которая уже на протяжении долгого времени имеет возможность ездить за границу, пробовать местную кухню, становится важным также хорошо разбираться и уметь готовить изысканные/экзотические блюда. В связи с этим молодежью востребованы рестораны и кафе с хорошей кухней, школы высокой кулинарии.

5) Спрос молодежи на товары необходимой «роскоши» дорогую одежду определенных марок, телефоны, i-pod, часы и т. д. в категории премиум-класса и Luxury, в связи с тем что, с одной стороны, у молодежи появилось больше денег, выделяемых родителями на карманные расходы, а с другой стороны, собственных заработанных денег. Теперь уже не достаточно выделяться среди сверстников за счет качественного товара, важно, чтобы он обязательно был модным, эксклюзивным и непременно достаточно дорогим. 
6) Активное потребительское поведение на рынке автомобилей. Сейчас никого не удивит молодой человек/девушка, подъезжающий к университету на автомобиле. Нередко можно услышать в коридорах университета жалобы на закрывающиеся мойки или некачественное топливо. Начиная с 18 лет молодые люди активно получают права, стремятся взять машину у родителей, а в продолжении - купить, часто в кредит, собственный автомобиль более престижной марки или модели, повышающей социальный статус владельца. Среди них уже имеется четкое понимание по поводу уместности использования определенных автомобильных брендов, например, выпускнику университета уместно ездить на автомобилях среднего класса стоимостью до 500 тыс. рублей, а после двух-трех лет работы нужно купить автомобиль уже других, более «статусных» брендов, например, BMW, Lexus стоимостью более 500 тыс. рублей.

7) Рост так называемой «кухни супермаркетов» для интенсивно работающих и преуспевающих молодых людей - замороженных полуфабрикатов или уже готовых блюд/салатов в категории «ready to eat», главным достоинством которых являются удобство и быстрота в приготовлении. Это объясняется тем, что современная молодежь, как студенческая, так и работающая, если к тому же она проживает отдельно от родителей, не имеет достаточного времени для занятия домашним хозяйством, в том числе и приготовлением пищи. Однако здесь возникает противоречие: с одной стороны, молодежи готовить некогда, поэтому она активно пользуется услугами полуфабрикатами, а с другой - выделяет специальное время на посещение курсов по приготовлению изысканных и оригинальных блюд, чтобы повысить свой социальный статус, «блеснуть» познаниями перед друзьями, знакомыми.

8) Приверженность молодежи здоровому образу жизни. Очень важно выглядеть здоровым и в хорошей физической форме, иметь совершенное тело, прокаченные и упругие мышцы. В результате в совокупности со здоровым питанием занятия спортом становятся все более актуальными. Все чаще молодые люди после учебы, работы регулярно занимаются спортом, фитнесом, йогой. 
Таким образом, исследование показало, что существует несколько проблем в комплексе взаимосвязанных социальных противоречий. Прежде всего это противоречие между стремлением молодежи к завышенным, по отношению к реальным покупательским возможностям, стандартам потребления: растущими потребностями в условиях постоянно расширяющегося потребительского рынка, с одной стороны, и отсутствием возможностей их удовлетворения вследствие низкого уровня жизни значительной части молодежи - с другой. Существующее в современном российском обществе глубокое расслоение по материальному признаку определяет многообразие потребительских практик молодежи. Модели потребления данной группы дифференцируются в зависимости от принадлежности семьи к определенному социальному слою, уровня дохода родителей, их образования, социально-профессионального статуса. Молодежи в большей мере свойственны практики самоутверждения через потребление, поэтому в молодежной среде особенно проявляется феномен демонстрационного потребления. Для молодых людей из обеспеченных семей потребление служит средством проявления индивидуальности и демонстрации широких материальных возможностей, носит идентификационный характер и выступает способом дистанцирования от представителей менее обеспеченных групп молодежи. Для последних потребление выполняет в большей мере утилитарную функцию, однако и в данном случае носит символический характер: редкое потребление дорогостоящих вещей дает ощущение принадлежности к более обеспеченным группам и приносит ярко выраженное эмоциональное ощущение удовольствия.

Социальное противоречие проявляется и в заинтересованности бизнеса и государства расширить покупательскую способность молодежи, с одной стороны, и отсутствием реальных материальных условий для ее реализации - с другой. Материальная обеспеченность является одним из ключевых факторов, определяющих особенности поведения. Взросление, сопровождаясь вовлечением молодежи в систему трудовых и социальных отношений, обретению социальной независимости, влечет к росту потребительского 150 
статуса. Как отмечают В. Б. Звоновский и С. И. Луцева, «с ростом дохода увеличивается лишь число посещений различных мероприятий. Выбор той или иной досуговой модели не связан с материальным обеспечением молодежи» [10].

Исследование показало, что молодежь обладает сложившейся системой базовых социальных ценностей и выбранных инструментов к их достижению. Социальные ценности, которые принимают и отвергают молодые россияне, во многом определяют их поведение как потребителей. Среди ценностей современной российской молодежи материальные ценности превалируют над духовными.

Центральными в системе ценностей молодого поколения в настоящее время стали индивидуализм и карьеризм. Указанные качества обеспечивают направленность потребительского поведения исключительно на удовлетворение личных потребностей и определяют спектр потребительских предпочтений, отражающий в большей степени модель потребления успешного человека, сформированную в сознании молодежи под воздействием СМК и рекламы. Ориентация молодежи на данную модель потребления инициирует потребность в безукоризненном внешнем облике, выработке собственного стиля и влечет приобретение модной одежды и разного рода модных аксессуаров. Кроме того, это влечет избрание представителями молодежи либо показательно престижных форм досуга в виде посещения салонов красоты и спортивных центров, оказывающих в большинстве своем дорогостоящие услуги, либо рекреативно-развлекательных форм, предполагающих посещение кафе, баров, дискотек, ночных клубов, чтение журналов развлекательного содержания, просмотр соответствующих передач по телевидению и т. д.

\section{Список литературы}

1. Ильин В. И. Потребление как дискурс : учеб. пособие / В. И. Ильин. СПб. : Интерсоцис, 2008. 446 с.

2. Магун В. С. Жизненные притязания ранней юности и стратегии их реализации: 90, 80-е годы / В. С. Магун, А. З. Литвинцева. М. : Институт социологии РАН, 1993. 61 с. 
3. Котлер Ф. Основы маркетинга / Ф. Котлер. М. : Бизнес-книга, Има-Кросс плюс, 1995. 155 с.

4. Радаев В. В. Социология потребления, основные подходы / В. В. Радаев. СоцИс. 2005. № 1. С. 5.

5. Ильин В.И. Быт и бытие молодежи российского мегаполиса / В. И. Ильин. СПб. : Интер-СоцИс, 2007. 388 с.

6. Бодрийяр Ж. Система вещей / Ж. Бодрийяр. М. : Рудомино, 2001. $174 \mathrm{c}$.

7. Павлова В. В. Рыночное мышление студенческой молодежи / В. В. Павлова // Социологические исследования. 1998. № 8. С. 138-139.

8. Мкртчян Г. М. Стратификация молодежи в сферах образования, занятости и потребления / Г. М. Мкртчян // Социологические исследования. 2005. № 2. С. 104-113.

9. Bourdieu P. Distinction: A Social Critique of the Judgment of Taste / P. Bourdieu. London : Routledge and Kegan Paul, 1984. P. 72-76.

10. Звоновский В. Б. Досуговые предпочтения молодежи мониторинг общественного мнения / В. Б. Звоновский, С. И. Луцева // Данные анализа дискуссии. 2004. № 4. С. 70-82.

\section{§ 3. Современные аспекты проектирования и оценки эффективности региональных логистических систем}

Развитие региональных транспортно-логистических систем имеет принципиальное значение для экономического развития России, хотя бы в силу ее большой и протяженной с запада на восток территории. Российская Федерация является своего рода потенциальным «распределительным центром», способным связать в единый транспортно-логистический узел Западную, Северную, Центральную и Восточную Европу и азиатский континент.

Современная концепция логистического управления предполагает изучение логистических цепей и систем как единой взаимосвязанной интегрированной сложной системы. Любая сложная система, в том числе и логистическая отличается такими свойствами, как эмерджентность, аддитивность и синергия. Все эти основные свойства комплексных структур организационных 152 
и логистических структур приводят в первую очередь к возникновению неопределенностей, противоречий и сбоев в их работе.

Присутствие в логистической системе свойств, характеризующих сложную систему, позволяет говорить о логистической системе как о системе вообще. Однако применительно к задачам логистики эти свойства приобретают конкретизированный характер.

1. Сложность логистической системы характеризуется следующими основными признаками: наличием большого числа элементов (звеньев); сложным характером взаимодействия между отдельными элементами; сложностью функций, выполняемых системой; наличием сложного организованного управления; воздействием на систему большого количества факторов внешней среды.

2. Иерархичность характеризует подчиненность элементов логистической системы более низкого уровня элементам более высокого уровня.

3. Целостность и членимость (эмерджентность). Элементы логистической системы должны работать как единое целое, что и является основополагающей концепцией логистического подхода. Без логистической системы эти элементы обладают лишь потенциальной способностью к объединению и совместной работе. Таким образом, заданная цель реализуется только логистической системой в целом, а не отдельными ее элементами (звеньями, подсистемами).

4. Структурированность предполагает наличие определенной организационной структуры логистической системы, состоящей из взаимосвязанных объектов и субъектов управления, реализующих заданную цель.

Логистическая система обладает интегративными качествами, которые позволяют реализовать основную цель логистики: поставить нужный товар в определенном количестве, нужного качества в нужное время в нужное место с минимальными затратами, эти качества также способствуют адаптации логистической системы к изменениям окружающей среды. Интегративные качества не 
свойственны ни одному элементу в отдельности, т. е. ни один элемент логистической системы в отдельности не сможет достичь обозначенных выше результатов, и, лишь действуя в одной системе (логистической системе), составляя единое целое, эти элементы могут проявлять себя именно с такими результатами.

Усложнение рыночных отношений и усиление конкуренции в настоящее время приводят к трансформации логистических систем, которая выражается в следующих основных моментах:

- возрастает скорость материального потока, увеличиваются интенсивность и сложность информационного потока, усложняются финансовые взаимоотношения между логистическими посредниками;

- сокращается число звеньев (агентов) логистической цепи, но сложность взаимоотношений возрастает;

- уменьшается надежность логистической цепи, так как практически исчезают запасы в производстве и распределительных сетях.

В России в настоящее время сложилась ситуация, когда существует множество различных логистических сетей, созданных крупными и малыми, государственными и частными компаниями. При этом каждая сеть нацелена на решение вопросов только той структуры, которой она создана. Это означает, что существует значительная конкуренция, вынуждающая компании постоянно вести конкурентную борьбу с другими сетями затрачивая дополнительные средства. Точно такая же ситуация сложилась и в других странах, как развитых, так и развивающихся. Поэтому одним из главных вопросов, требующих скорейшего решения, является вопрос о создании концептуальной научно-исследовательской базы для разработки единой методологии создания, развития и оценки эффективности работы интегрированных логистических систем как на международном и национальном, так и на региональном уровне.

Основная методологическая сложность в исследовании сложных логистических систем заключается в том, что до настоящего 154 
времени нет единого общепринятого представления или определения понятия «региональная логистическая система».

Современные определения и формулировки понятия «региональная логистическая система» имеют ряд существенных недостатков, среди которых можно выделить следующие:

- во-первых, часто существующие определения искусственно ограничивают круг участников региональной логистической системы (РЛС) только юридическими лицами, что не представляется верным и целесообразным. Практика показывает, что среди участников практически любой РЛС можно встретить и юридических лиц различного организационно-правового статуса, и физических лиц (например, собственники грузового и пассажирского автотранспорта, имеющие статус индивидуального предпринимателя). Вдобавок заинтересованные группы общественности также могут являться участниками (пусть и косвенными) региональной логистической системы;

- во-вторых, в большинстве определений участники РЛС определяются как «юридически самостоятельные» субъекты. Из этого следует, что, например, зависимые и дочерние организации не могут являться отдельно рассматриваемыми участниками региональных логистических систем, что тоже является неверным представлением;

- в-третьих, определения не включают сервисную составляющую РЛС;

- в, наконец, в-четвертых, большинство определений региональных логистических систем слишком усложнены, что делает их малопонятными.

Учитывая вышесказанное, представляется необходимым предложить более понятное, емкое и полное определение региональной логистической системы. Это необходимо в первую очередь для того, чтобы на основании данного определения разработать методологический аппарат создания и оценки эффективности работы РЛС. 
Поэтому предлагается следующее определение региональной логистической системы:

Региональная логистическая система - это организащионно-управленческий механизм, обрабатьвающий и распределяющий логистические потоки (основные и вспомогательные) среди участников системы на уровне отдельного региона.

Это определение представляется более обоснованным в силу следующих факторов:

1. Определение представляет региональную логистическую систему в более общем, не избыточно конкретизированном виде.

2. Определение включает все необходимые компоненты региональной логистической систему.

3. В определение введено понятие региональной логистической системы как организационно-управленческого, а не только распределительного механизма.

Основываясь на разработанном определении региональной логистической системы, представляется возможным разработать управленческую методологию разработки, создания, деятельности и оценки эффективности РЛС на примере Свердловской области как региона, обладающего значительным потенциалом для развития региональных логистических подсистем в рамках единой интегрированной региональной системы.

Одним из основных современных подходов к вопросу создания единого логистического пространства не только на региональном, но и на трансрегиональном и национальном уровне является объединение логистических центров регионов с логистическими центрами компаний и образование транспортно-экспедиционной логистически-информационной сети на уровне региона. Таким образом, подсистема логистического обеспечения компании становится некоторой подсистемой низшего уровня в единой логистической сети региона. 
Задачи, решаемые региональной логистической системой, можно разделить на три группы:

1. Задачи, связанные с формированием рыночных зон обслуживания, прогнозом грузопотока, его обработкой в обслуживающей системе (склад поставщика и потребителя, предприятия транспорта) и другими работами по оперативному управлению и регулированию материального потока.

2. Задачи, включающие разработку системы организации транспортного процесса (план перевозок, план распределения вида деятельности, план формирования грузопотоков, график движения транспортных средств и др.).

3. Задачи, связанные с интегрированным управлением запасами на предприятиях, фирмах, складских комплексах, размещение запасов и их обслуживание транспортными средствами, информационными системами (рис. 13).

В настоящее время не существует исчерпывающей классификации РЛС, которая позволила бы разработать методологический инструментарий создания, функционирования и оценки эффективности их деятельности.

Такая классификация должна учитывать следующие факторы (рис. 14):

1. Экономико-географичекое положение региона (специализация хозяйственной инфраструктуры региона).

2. Кооперативные связи региона с другими субъектами Российской Федерации.

3. Ситуацию на региональном рынке труда.

4. Степень развития логистической инфраструктуры.

Классификация по экономико-географическому положению нужна для анализа возможности и необходимости размещения РЛС в том или ином регионе.

Классификация по кооперативным связям необходима для технико-экономического анализа возможностей создания и развития РЛС и анализа уровня инвестиций. 

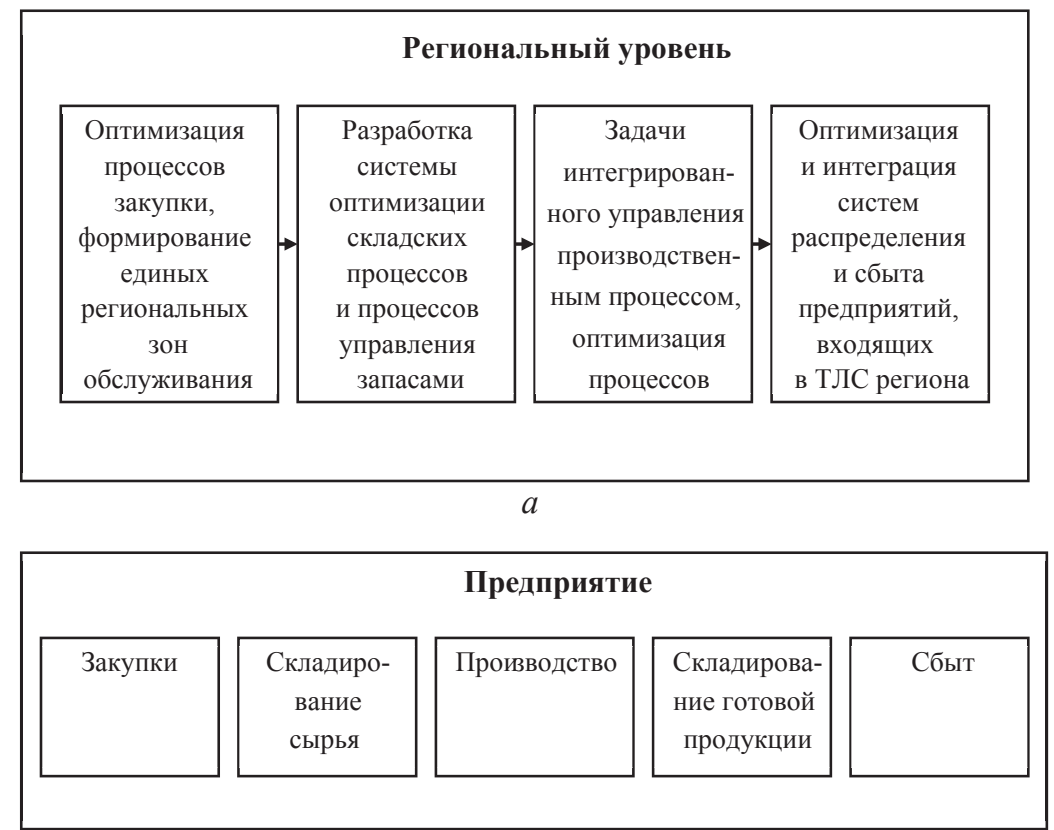

$\sigma$

Рис. 13. Задачи, решаемые логистическими системами предприятия и РЛС:

$a$ - на региональном уровне; $\sigma$ - на уровне предприятия

Классификация по ситуации на региональном рынке труда нужна для определения потребности в специальных кадрах для РЛС.

Классификация по степени развития логистической инфраструктуры дает перспективы развития, стратегического планирования, оценки инвестиций.

Исходя из предложенной классификации, возможно говорить о создании на ее основе методики оценки эффективности РЛС с учетом ее региональной специфики. Таким образом, эффективность РЛС можно оценить по четырем основным показателям:

1. Экономико-географичекое положение региона (специализация хозяйственной инфраструктуры региона). 
2. Кооперативные связи региона с другими субъектами Российской Федерации.

3. Ситуацию на региональном рынке труда.

4. Степень развития логистической инфраструктуры.

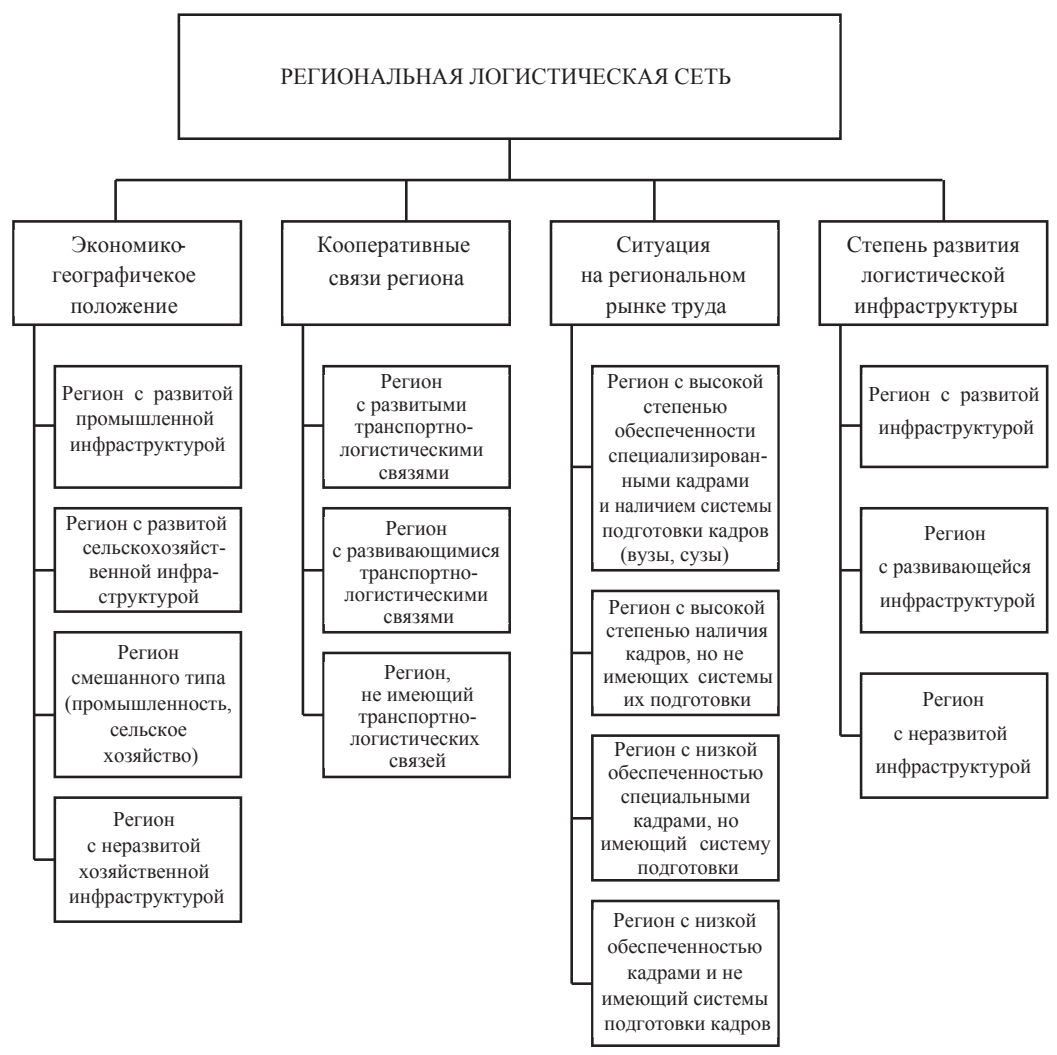

Рис. 14. Классификация РЛС

Исходя из занимаемого положения, по каждому квалификационному показателю можно говорить о специфических требованиях к логистической системе, дальнейшая оценка должна происходить по определению достаточно универсального параметра - логистические затраты в цепи управления поставками или прибыль, 
которая образуется при продвижении материалопотока, причем общими ключевыми показателями эффективности любой логистической системы являются:

1. Совокупность логистических издержек.

2. Уровень качества логистического сервиса.

3. Общая производительность бизнес-системы.

4. Общая продолжительность логистических процессов в системе.

5. Качество логистических операций и процессов (уровень логистического сервиса). 


\section{ЗАКЛЮЧЕНИЕ}

Происходящие в экономике негативные изменения основных макроэкономических показателей отражают негативные тенденции в развитии институциональной среды и конкурентоспособности предприятий. Можно многое списать на кризис, но это будет справедливо лишь отчасти. Сейчас темпы роста российской экономики ниже, чем в основных развивающихся странах. Но, что особенно важно, ниже, чем в развитых странах, которые традиционно отличаются низкими темпами роста.

Даже радикальное увеличение государственных инвестиций не может компенсировать спад производительности труда. Требуется радикальное улучшение инвестиционного климата при усилении стимулов к конкуренции. Одной из причин затухания роста производительности труда является консервации ресурсной модели экономики, для которой характерны технологическая отсталость и недостаток конкуренции.

Российские предприятия, работающие в условиях очень разнообразной внешней среды, демонстрируют высокий уровень внутриотраслевых и межотраслевых разрывов в эффективности использования ресурсов, рентабельности производства, конкурентоспособности. Это наиболее остро проявляется в условиях кризиса. Как и в предыдущие экономические кризисы, рассмотренные в данной монографии (1998 и 2008 гг.), кризис 2014 г. проявил большое разнообразие ответных шагов и антикризисных стратегий предприятий, при этом разные отрасли и разные компании внутри этих отраслей и секторов экономики вошли в кризис в разное время. Логично предположить, что и скорость выхода из нынешнего кризиса будет у компаний неравномерной, особенно если учесть, что кризис 2014 г. — это лишь начало затяжного мирового кризиса, предсказать окончание которого не берутся сейчас эксперты. Дополнительной сложностью для предприятий 
в принятии стратегических решений является влияние геополитических факторов, усложняющих условия работы.

Для всех компаний независимо от размера на первый план в стратегических решениях выходит фактор потребителя, который определяет не только финансовую устойчивость компаний, но и границы рынков, а также сами отрасли в противовес технологическому подходу. Глобализация становится также фактором, влияющим на работу всех компаний, даже в неторгуемых отраслях, так как от внешних рынков в ресурсоориентированной экономике зависит ВВП страны и бюджеты потребителей как для В2В, так и для В2С рынков. По итогам исследований также выявлено особое внимание к качеству трудовых ресурсов, которые становятся стратегическим ресурсом в кризис. Крупный бизнес же отличает еще и система взаимоотношений с государством всех уровней.

В представленной монографии рассмотрены особенности экономического поведения российских компаний в среднесрочной перспективе. Работа представляет собой пример исследовательских подходов к изучению сложного объекта, что подчеркивает ее мотивационное значение для последующих работ, стимулируя новые темы и приемы в анализе многообразия поведенческих реакций предприятий. Коллективная работа такого типа является попыткой восполнить пробел в информации о поведенческих особенностях российских предприятий. При всей фрагментарности исследований, проведенных авторами, в первую очередь именно эту задачу и призвана выполнить эта монография. 


\section{АВТОРЫ}

Букис В. В. - старший преподаватель кафедры теории и практики менеджмента, ВШЭМ, УрФУ.

Гиниятуллин Р. Н. - кандидат экономических наук, доцент кафедры теории и практики менеджмента, ВШЭМ, УрФУ.

Емельянова Е. В. - ассистент кафедры теории и практики менеджмента, ВШЭМ, УрФУ.

Зубакина Д. А. - старший преподаватель кафедры теории и практики менеджмента, ВШЭМ, УрФУ.

Калабина Е. Г. - доктор экономических наук, профессор кафедры теории и практики менеджмента, ВШЭМ, УрФУ.

Костылева Н. В. - кандидат социологических наук, доцент кафедры теории и практики менеджмента, ВШЭМ, УрФУ.

Петров А. Ю. - кандидат социологических наук, доцент кафедры теории и практики менеджмента, ВШЭМ, УрФУ.

Петров Е. А. - кандидат социологических наук, кафедры теории и практики менеджмента, ВШЭМ, УрФУ.

Пискунова Л. П. - кандидат философских наук, доцент кафедры теории и практики менеджмента, ВШЭМ, УрФУ.

Подковырова К. П. - студентка 4-го курс ВШЭМ, УрФУ.

Пьянков А. Г. - старший преподаватель кафедры теории и практики менеджмента, ВШЭМ, УрФУ.

Ружанская Л. С. - доктор экономических наук, доцент кафедры теории и практики менеджмента, ВШЭМ, УрФУ.

Фонова Н. Г. - кандидат экономических наук, доцент кафедры теории и практики менеджмента, ВШЭМ, УрФУ.

Якимова Е. А. - старший преподаватель, кафедры теории и практики менеджмента, ВШЭМ, УрФУ.

Яшин А. А. - кандидат экономических наук, доцент кафедры теории и практики менеджмента, ВШЭМ, УрФУ. 


\section{ОГЛАВЛЕНИЕ}

\section{ИЗМЕНЕНИЕ СТРАТЕГИЙ РОССИЙСКИХ ПРЕДПРИЯТИЙ \\ В УСЛОВИЯХ ЭКОНОМИЧЕСКИХ КРИЗИСОВ}

\section{Глава 1 \\ ОСОБЕННОСТИ ЭКОНОМИЧЕСКОГО ПОВЕДЕНИЯ РОССИЙСКИХ ПРЕДПРИЯТИЯ}

$\S 1$. Закрытый тип экономического поведения крупного российского бизнеса: опыт монографического исследования ............ 7

$\S 2$. Российские предприятия в современных условиях:

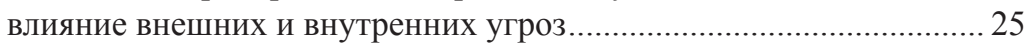

$\S 3$. Дилемма профсоюзов в переговорном процессе работников и работодателей: выбор между занятостью и оплатой труда? ......... 28

$\S 4$. Стратегическое партнерство государства и бизнеса в России и зарубежом

\section{Глава 2}

ГЛОБАЛИЗАЦИЯ РОССИЙСКОЙ ЭКОНОМИКИ КАК ДЕТЕРМИНАНТА ЭКОНОМИЧЕСКОГО ПОВЕДЕНИЯ РОССИЙСКИХ ПРЕДПРИЯТИЙ

$\S 1$. «Геополитический кризис»: барьеры и возможности для предприятий малого бизнеса . 65

$\S 2$. Возможности использования китайской экспансии для развития экономики Свердловской области. 83

\section{Глава 3}

\section{СТРАТЕГИИ РАЗВИТИЯ РОССИЙСКИХ ПРЕДПРИЯТИЙ В УСЛОВИЯХ КРИЗИСА}

$\S 1$. Сессия организационного развития как платформа генерации прорывных идей в бизнесе

$\S 2$. Сохранение лояльности клиентов в ресторанном бизнесе компании «Юниверфуд» в контексте развивающегося кризиса потребительской активности 2014-2015 гг. 


\section{Глава 4}

\section{ОСОБЕННОСТИ РАЗВИТИЯ РЫНКОВ}

$\S 1$. От легкой промышленности к индустрии моды: направления развития предприятий отрасли .................................... 119

$\S 2$. Основные тенденции потребительского поведения современной молодежи .............................................................. 138

§ 3. Современные аспекты проектирования и оценки эффективности региональных логистических систем 152

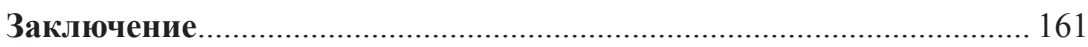

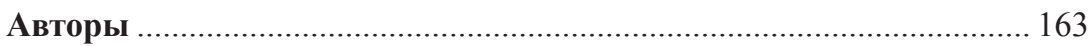




\section{БАРЬЕРЫ И ВОЗМОЖНОСТИ ДЛЯ РАЗВИТИЯ БИЗНЕСА В РОССИЙСКОЙ ЭКОНОМИКЕ}

Редактор Е. Е. Крамаревская

Корректор Е. Е. Крамаревская

Компьютерная верстка $Н$. Ю. Михайлов

Ответственный за выпуск Шакирзянова Д. Д.

Формат $60 \times 84 \frac{11}{16}$. Уч.-изд. л. 9,5.

Издательство Уральского университета 620000 , Екатеринбург, ул. Тургенева, 4

Тел.: +7 (343) 350-56-64, 350-90-13.

Факс: +7 (343) 358-93-06.

E-mail: press-urfu@mail.ru 
